\title{
ipen
}

Autarquia Associada à Universidade de São Paulo

\section{OBTENÇÃO DE MEMBRANAS POLIMÉRICAS FLUORADAS PARA USO EM CÉLULAS A COMBUSTÍVEL}

ADRIANA NAPOLEÃO GERALDES

Tese apresentada como parte dos requisitos para obtenção do Grau de Doutor em Ciências na Área de Tecnologia Nuclear-Materiais.

Orientador:

Dr. Ademar Benévolo Lugão

SÃO PAULO 


\section{ipen}

Autarquia Associada à Universidade de São Paulo

\section{OBTENÇÃO DE MEMBRANAS POLIMÉRICAS FLUORADAS PARA USO EM CÉLULAS A COMBUSTÍVEL}

ADRIANA NAPOLEÃO GERALDES

Tese apresentada como parte dos requisitos para obtenção do Grau de Doutor em Ciências na Área de Tecnologia Nuclear-Materiais.

Orientador:

Dr. Ademar Benévolo Lugão

SÃO PAULO 
A meus pais, Jayme (in memorian) e Antonia por todo apoio dedicação e confiança. À Alexandra, Jayme, Beatrice, Robinho e Robson pela alegria. 
"Tudo tem o seu tempo determinado, e há tempo para todo o propósito abaixo do céu. Há tempo de plantar e tempo de se colher o que se plantou."

Eclesiastes, 3. 


\section{AGRADECIMENTOS}

Ao meu orientador Dr. Ademar Benévolo Lugão pela orientação, dedicação e interesse. E principalmente pela oportunidade de aprendizagem.

Ao Instituto de Pesquisas Energéticas e Nucleares (IPEN/CNEN-SP) pela oportunidade de desenvolver este trabalho.

Ao Conselho Nacional de Desenvolvimento Científico e Tecnológico (CNPq) pela bolsa concedida.

À EMBRARAD/CBE pelas irradiações.

Ao Dr. Marcelo Linardi do Centro de Célula a Combustível e Hidrogênio (CCCH) do IPEN/CNEN-SP pela oportunidade de estudo e pela orientação no início deste trabalho.

À Dra. Duclerc Fernandes Parra do Centro de Química e Meio Ambiente (CQMA) do IPEN/CNEN-SP por sua ajuda durante todo desenvolvimento deste trabalho, pela confiança e pela amizade.

À Dra. Elisabete I. Santiago do Centro de Célula a Combustível e Hidrogênio $(\mathrm{CCCH})$ do IPEN/CNEN-SP por disponibilizar a estação de testes para a realização das curvas de polarização deste trabalho.

À MSc. Heloísa Augusto Zen por tudo.

Ao Sr. Eleosmar Gasparin do Centro de Química e Meio Ambiente (CQMA) do IPEN/CNEN-SP pelas análises térmicas. 
À Sra. Sandra Maria Cunha do Centro de Ciência e Tecnologia dos Materiais do (CCTM) IPEN/CNEN-SP, pelas análises de espectroscopia no infravermelho.

Aos Srs. Celso Vieira, Nildemar Ferreira e Glauson Machado do Centro de Ciência e Tecnologia dos Materiais (CCTM) IPEN/CNEN-SP, pelas análises de microscopia eletrônica de varredura (MEV).

Aos meus amigos do CQMA: Henrique, Camila, Maria, Geise, Gilberto, Hélio Ferreto, Beth, Harumi, Adriana Yoshiga, Sivelton, Mara, Renata, Roberta, Amanda, Jacinete, Kiriaki, Takeshi, João, Ricardinho, Pereira, Filipe, Mitiko, Brandão, Claudia Felinto, Oscar, Ruth, Nelson, Pedro Forster, Pedro Vicente, Patrícia, Natália e Rodrigo, pelo carinho, incentivo e amizade.

Aos amigos do CCCH: Dionísio, Roberta, Mauro, Martha Lucia, Carolina, Luciana, Roberto Willyan, Eric, Edgar, Estevam, Almir, Rafael, Ricardo, Gustavo, Bruno, Rudy, Vilmaria, Michele e Marcelo, pelo carinho e amizade. 


\title{
OBTENÇÃO DE MEMBRANAS POLIMÉRICAS FLUORADAS PARA USO EM CÉLULAS A COMBUSTÍVEL
}

\author{
ADRIANA NAPOLEÃO GERALDES
}

\begin{abstract}
RESUMO
A enxertia de estireno induzida pela radiação gama nos filmes fluorados, poli(tetrafluoroetileno-co-hexafluoropropileno) (FEP), poli(etileno-cotetrafluoroetileno) (ETFE), poli(fluoreto de vinilideno) (PVDF), poli(tetrafluoroetileno-co-perfluoro alquil vinil eter) (PFA) e poli(tetrafluoroetileno) (PTFE) foi realizada pelo método simultâneo de irradiação utilizando uma fonte de cobalto-60. Os filmes fluorados foram imersos em soluções de estireno/tolueno, estireno/isopropanol e estireno/metanol $(1: 1 \mathrm{v} / \mathrm{v})$ sob atmosfera inerte $\mathrm{e}$ temperatura ambiente e, então, submetidos a doses de 20, 40, 80 e 100 kGy. Após a reação de enxertia os filmes foram mantidos à temperatura ambiente, e ainda sob atmosfera inerte, por 7, 14, 21 e 28 dias para avaliar a variação no grau de enxertia em relação ao tempo de pós-irradiação. No final de cada período os filmes foram sulfonados para conferir às membranas fluoradas a propriedade de hidrofilicidade. $\mathrm{O}$ grau de enxertia (DOG) foi determinado gravimetricamente e as mudanças químicas e morfológicas nos filmes enxertados e sulfonados foram analisadas por espectroscopia no infravermelho, termogravimertria (TG), calorimetria exploratória diferencial (DSC), microscopia eletrônica de varredura (MEV) e capacidade de troca iônica (IEC). Os testes em célula a combustível foram, também, efetuados pelo levantamento de curvas de polarização. Pela técnica de espectroscopia no infravermelho foi possível confirmar a presença do estireno nos filmes enxertados. O grau de enxertia nos filmes fluorados foi dependente do tipo de solvente utilizado. A análise termogravimétrica dos filmes enxertados mostrou duas etapas de decomposição, enquanto que a dos filmes sulfonados mostrou quatro. Pelos dados de DSC dos filmes enxertados constatou-se pequena variação na temperatura do pico de fusão, sugerindo a formação de poliestireno enxertado pouco penetrado na matriz polimérica. As figuras de MEV mostraram que o solvente tem maior influência na morfologia dos enxertos do que a dose de irradiação. Os testes em célula das membranas de ETFE, PFA e FEP apresentaram uma resposta de polarização satisfatória quando comparadas à membrana comercial Nafion ${ }^{\circledR}$.
\end{abstract}




\title{
POLYMER FLUORINATED MEMBRANES FOR FUEL CELLS
}

\author{
ADRIANA NAPOLEÃO GERALDES
}

\begin{abstract}
The radiation-induced graft of styrene onto fluoropolymers, poly(tetrafluoroethylene-co-hexafluoropropylene) (FEP), poly(ethylene-cotetrafluoroethylene) (ETFE), poly(vinylidene fluoride) (PVDF), poly(tetrafluoroethylene-co-perfluoroalquil vinyl ether) (PFA), and poly(tetrafluoroethylene) was carried out by simultaneous irradiation method in a cobalt-60 source. The fluoropolymers films were immersed in solutions of styrene/toluene, styrene/isopropilic alcohol and styrene/methanol $(1: 1 \mathrm{v} / \mathrm{v})$ under inert atmosphere and at room temperature and then submitted to 20,40, 80, and 100 kGy. After grafting reaction the films were kept at room temperature under inert atmosphere for periods of $7,14,21$ and 28 days in order to evaluate the degree of grafting. At the end of each period, the films were sulfonated to provide the hydrophilic property to fluoropolymer membranes. The degree of grafting (DOG) was gravimetrically determined and the chemical changes in the grafted and sulfonated films were characterized by infrared spectroscopy, thermogravimetric analysis (TGA), differential scanning calorimetry (DSC), scanning electron microscopy (SEM), and ion exchange capacity (IEC) was calculate. Single fuel cell measurements of ETFE, FEP and PFA membranes were performed. New bands attributed to styrene grafted in a fluoropolymers films were observed by FTIR spectra. The degrees of grafting of fluorinated films were solvent dependent. By TGA the grafted films exhibited two steps of degradation and the sulfonated membranes exhibited four steps of degradation. By DSC was possible to verify that matrix polymerics did not suffer any drastic change in the melting temperature after grafting and sulfonation reactions. The SEM images of grafted and sulfonated films showed the morphology depends strongly on the solvent used. The fuel cell performance of ETFE, FEP and PFA films was satisfactory when compared to state-of-art Nafion ${ }^{\circledR}$ membranes.
\end{abstract}




\section{SUMÁRIO}

1 INTRODUÇÃO

2 OBJETIVO

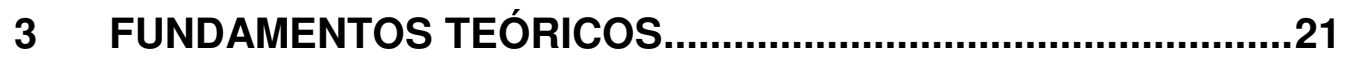

3.1 Célula a combustível ..........................................................21

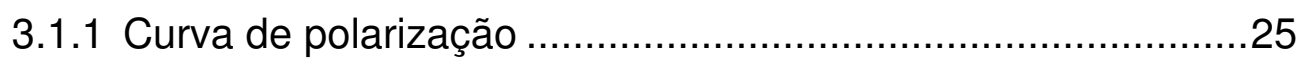

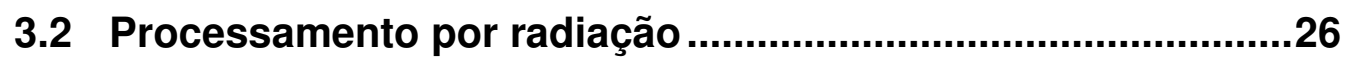

3.3 Filmes poliméricos para enxertia ………….............................30

3.4 Efeito do solvente e sulfonação ...............................................35

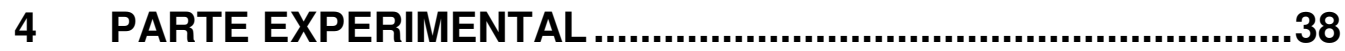

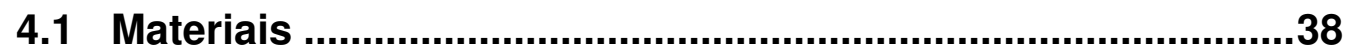

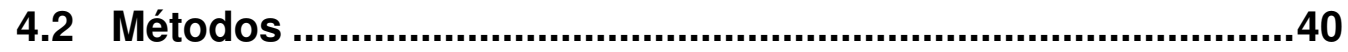

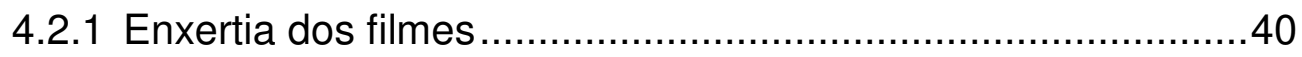

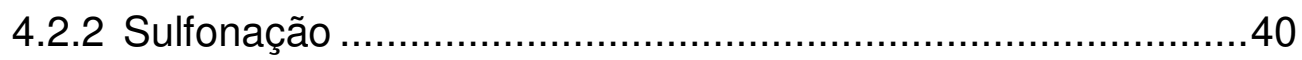

4.2.3 Preparo das membranas para confecção dos MEAs ...............41

4.2.4 Preparo dos eletrodos ........................................................ 41

4.2.5 Preparo do conjunto membrana eletrodos .............................42

4.3 Caracterização dos filmes e membranas .................................42

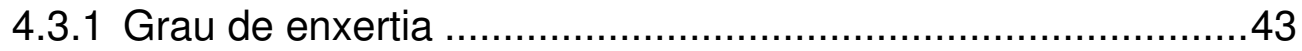

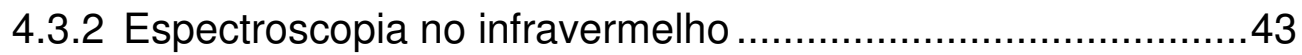

4.3.3 Microscopia eletrônica de varredura ……..............................43

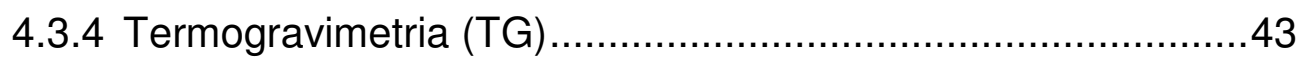

4.3.5 Calorimetria exploratória diferencial (DSC) ............................4

4.3.6 Cálculo da capacidade de troca iônica (IEC) …….................45 
5.1 Estabilidade dos filmes à radiação.

5.2 Enxertia nos filmes em diferentes solventes.........................52

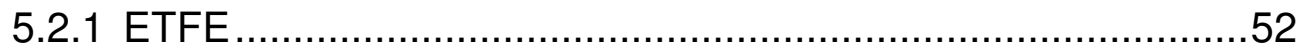

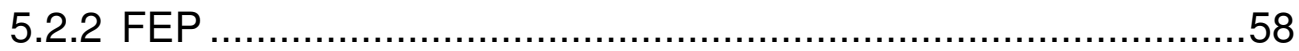

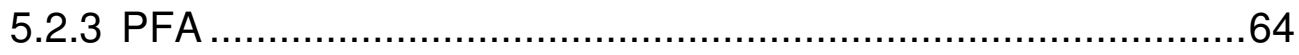

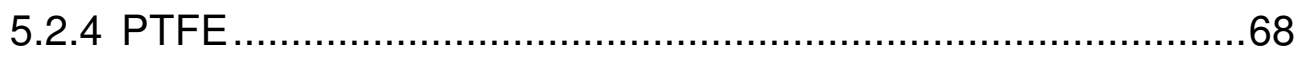

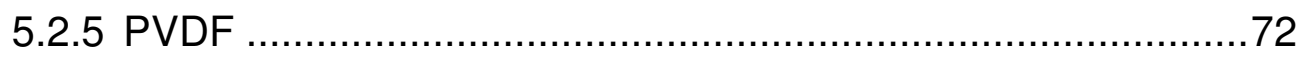

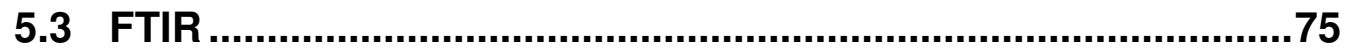

5.4 Microscopia eletrônica de varredura.....................................76

5.5 Efeito do solvente do estireno na enxertia ...........................90

5.6 Capacidade de troca iônica das membranas sulfonadas.......91

5.7 Testes em célula - curvas de polarização.............................100

6 CONCLUSÃO ..................................................................... 109

7 TRABALHOS FUTUROS ........................................................110

REFERÊNCIAS BIBLIOGRÁFICAS................................................111 


\section{ÍNDICE DE TABELAS}

TABELA 1 Fluoropolímeros estudados 20

TABELA 2 Procedência dos fluoropolímeros estudados. 38

TABELA 3: Valores da entalpia de fusão dos polímeros $100 \%$ cristalinos. .44

TABELA 4: Valores de $T_{\text {onset }}$ obtidos por TG para os filmes de ETFE, FEP, PFA, PTFE e PVDF prístino e irradiados nas doses de 20, 40, 80 e 100 kGy. 49

TABELA 5: Valores obtidos na análise de DSC para os filmes de ETFE, FEP, PFA, PTFE e PVDF prístino e irradiados nas doses de 20, 40, 80 e 100 kGy. .51

TABELA 6: Valores obtidos na análise de DSC para os filmes de PFA prístino e enxertados nas doses de 20, 40, 80 e 100 kGy. .68

TABELA 7: Valores obtidos na análise de DSC para os filmes de PTFE prístino e enxertados nas doses de 20, 40, 80 e 100 kGy. .72

TABELA 8: Capacidade de troca iônica (IEC) experimental e teórica para as membranas de ETFE no tempo de sulfonação de 4 horas. Doses de 20 a 100 kGy.

TABELA 9: Capacidade de troca iônica (IEC) experimental e teórica para as membranas de FEP no tempo de sulfonação de 4 horas. Doses de 20 a 100 kGy.

TABELA 10: Capacidade de troca iônica (IEC) experimental e teórica para as membranas de PFA no tempo de sulfonação de 4 horas. Doses de 20 a 100 kGy. 
TABELA 11: Capacidade de troca iônica (IEC) experimental e teórica para as membranas de PTFE no tempo de sulfonação de 4 horas. Doses de 20 a 100 kGy. .96

TABELA 12: Capacidade de troca iônica (IEC) experimental e teórica para as membranas de ETFE, FEP e PFA no tempo de sulfonação de 4 horas. Dose de 20 kGy. 100 


\section{ÍNDICE DE FIGURAS}

FIGURA 1: Componentes de uma célula PEM unitária [20]. .22

FIGURA 2: Desenho esquemático de uma célula a combustível. 23

FIGURA 3: Esboço de uma curva de polarização. 25

FIGURA 4: Rotas de preparação para filmes enxertados e sulfonados. 29

FIGURA 5: Estação de testes. 46

FIGURA 6: Célula a combustível de $5 \mathrm{~cm}^{2}$ aberta destacando-se o MEA. 46

FIGURA 7: Espectros de infravermelho dos filmes ETFE (a) e FEP (b) prístino e expostos à radiação.

FIGURA 8: Grau de enxertia (DOG) para os filmes de ETFE (a) em tolueno, (b) em isopropanol e (c) em metanol.

FIGURA 9: Curvas termogravimétricas (a) e de DSC (b) do ETFE prístino e enxertado no período de 14 dias, nas doses 20, 40, 80 e 100 kGy em tolueno. ..54

FIGURA 10: Curvas termogravimétricas (a) e de DSC (b) do ETFE prístino e enxertado no período de 14 dias, nas doses 20, 40, 80 e 100 kGy em isopropanol. .55

FIGURA 11: Curvas termogravimétricas (a) e de DSC (b) do ETFE prístino e enxertado no período de 14 dias, nas doses 20, 40, 80 e 100 kGy em metanol. .56

FIGURA 12: Grau de enxertia (DOG) para os filmes de FEP (a) em tolueno, (b) em isopropanol e (c) em metanol. 
FIGURA 13: Curvas termogravimétricas (a) e de DSC (b) do FEP prístino e enxertado no período de 14 dias, nas doses 20, 40, 80 e 100 kGy em tolueno.

FIGURA 14: Curvas termogravimétricas (a) e de DSC (b) do FEP prístino e enxertado no período de 14 dias, nas doses 20, 40, 80 e 100 kGy em isopropanol.

FIGURA 15: Curvas termogravimétricas (a) e de DSC (b) do FEP prístino e enxertado no período de 14 dias, nas doses 20, 40, 80 e 100 kGy em metanol. .63

FIGURA 16: Grau de enxertia (DOG) para os filmes de PFA (a) em tolueno, (b) em isopropanol e (c) em metanol. .65

FIGURA 17: Curvas termogravimétricas do PFA prístino e enxertado no período de 14 dias, nas doses 20, 40, 80 e 100 kGy (a) em tolueno, (b) em isopropanol e (c) em metanol.

FIGURA 18: Grau de enxertia (DOG) para os filmes de PTFE (a) em tolueno, (b) em isopropanol e (c) em metanol.

FIGURA 19: Curvas termogravimétricas do PTFE prístino e enxertado no período de 21 dias, nas doses 20, 40, 80 e 100 kGy (a) em tolueno, (b) em isopropanol e (c) em metanol. .71

FIGURA 20: Grau de enxertia (DOG) para os filmes de PVDF (a) em tolueno, (b) em isopropanol e (c) em metanol. .74

FIGURA 21: Espectros dos filmes de ETFE prístino e enxertados no solvente tolueno nas doses de 20 a $100 \mathrm{kGy}$. .76

FIGURA 22: Imagens de MEV da superfície dos filmes Nafion ${ }^{\circledR} 115$ (a), ETFE prístino (b), irradiados a 20 (c) e 100 kGy (d). Ampliação de 5000 X .77 
FIGURA 23: Imagens de MEV da superfície de filmes de ETFE enxertados (a, b) e sulfonados (c, d) em tolueno 20 e 100 kGy. Ampliação de 5000 X. .78

FIGURA 24: Imagens de MEV da superfície de filmes de ETFE enxertados (a, b) e/ou sulfonados (c, d) em metanol 20 e 100 kGy. Ampliação de 5000 X. .79

FIGURA 25: Imagens de MEV da superfície de filmes de ETFE enxertados (a, b) e/ou sulfonados (c, d) em isopropanol 20 e 100 kGy. Ampliação de 5000 X.......80

FIGURA 26: Imagens de MEV da superfície de filmes de PTFE prístino (a) e irradiado (a 20 e 100 kGy). Ampliação de 5000 X

FIGURA 27: Imagens de MEV da superfície de filmes de PTFE enxertados (a, b) e/ou sulfonados (c, d) em tolueno 20 e 100 kGy. Ampliação de 5000 X

FIGURA 28: Imagens de MEV da superfície de filmes de PTFE enxertados (a, b) e/ou sulfonados (c, d) em metanol 20 e 100 kGy. Ampliação de 5000 X

FIGURA 29: Imagens de MEV da superfície de filmes de PTFE enxertados ( $a, b)$ e/ou sulfonados (c, d) em isopropanol 20 e 100 kGy. Ampliação de 5000 X.......84

FIGURA 30: Imagens de MEV da superfície de filmes de PVDF prístino (a) e enxertado a $20 \mathrm{kGy}$ nos solventes (b) tolueno, (c) metanol e (d) isopropanol. Ampliação de $5000 \mathrm{X}$. .85

FIGURA 31: Imagens de MEV da superfície de fratura dos filmes $\operatorname{Nafion}^{\circledR}(a, b)$ e ETFE (c, d) prístino. .86

FIGURA 32: Imagens de MEV da superfície de fratura dos filmes de ETFE enxertados em tolueno (a, b), isopropanol (c, d) e metanol (e, f). Fratura mecânica.

FIGURA 33: Imagens de MEV da superfície de fratura dos filmes de ETFE enxertados em tolueno (a-d) e metanol (e-h) e, posteriormente, sulfonados. Fratura em nitrogênio liquido. 
FIGURA 34: Curvas termogravimétricas do ETFE prístino, enxertado em tolueno, isopropanol e metanol na dose de $20 \mathrm{kGy}$ e, posteriormente, sulfonado.

FIGURA 35: Curvas de DSC das membranas de FEP (a), PFA (b) e ETFE (c).

FIGURA 36: Curvas de polarização em célula unitária. Eletrólitos: Nafion $^{\circledR} \mathrm{e}$ ETFE. Temperatura da célula $80{ }^{\circ} \mathrm{C}, \mathrm{H}_{2}$ umidificado a $95{ }^{\circ} \mathrm{C}$ e $\mathrm{O}_{2}$ umidificado a $85{ }^{\circ} \mathrm{C}$ 101

FIGURA 37: Curvas de polarização em célula unitária. Eletrólitos: Nafion ${ }^{\circledR}$ e FEP. Temperatura da célula $80{ }^{\circ} \mathrm{C}, \mathrm{H}_{2}$ umidificado a $95{ }^{\circ} \mathrm{C}$ e $\mathrm{O}_{2}$ umidificado a $85{ }^{\circ} \mathrm{C} . .102$

FIGURA 38: Curvas de polarização em célula unitária. Eletrólitos: Nafion ${ }^{\circledR}$ e PFA. Temperatura da célula $80{ }^{\circ} \mathrm{C}, \mathrm{H}_{2}$ umidificado a $95{ }^{\circ} \mathrm{C}$ e $\mathrm{O}_{2}$ umidificado a $85{ }^{\circ} \mathrm{C}$ 103

FIGURA 39: Curvas de polarização (a) e curvas de densidade de potência (b). Eletrólitos: Nafion ${ }^{\circledR}$ e ETFE. Temperatura da célula $80{ }^{\circ} \mathrm{C}, \mathrm{H}_{2}$ umidificado a $80{ }^{\circ} \mathrm{C}$ e $\mathrm{O}_{2}$ seco. 105

FIGURA 40: Curvas de polarização (a) e curvas de densidade de potência (b). Eletrólitos: Nafion ${ }^{\circledR}$ e FEP. Temperatura da célula $80{ }^{\circ} \mathrm{C}, \mathrm{H}_{2}$ umidificado a $80{ }^{\circ} \mathrm{C}$ e $\mathrm{O}_{2}$ seco. 106

FIGURA 41: Curvas de polarização (a) e curvas de densidade de potência (b). Eletrólitos: Nafion ${ }^{\circledR}$ e PFA. Temperatura da célula $80{ }^{\circ} \mathrm{C}, \mathrm{H}_{2}$ umidificado a $80{ }^{\circ} \mathrm{C}$ e $\mathrm{O}_{2}$ seco. 107 


\section{LISTA DE ABREVIAÇÕES}

\begin{tabular}{|c|c|}
\hline PEM & do inglês proton exchange membrane \\
\hline DMFC & Direct Methanol Fuel Cell \\
\hline FEP & poli(tetrafluoroetileno-co-hexafluoropropileno) \\
\hline ETFE & poli(etileno-co-tetrafluoroetileno) \\
\hline PVDF & poli(fluoreto de vinilideno) \\
\hline PFA & poli(tetrafluoroetileno-co-perfluoro alquil vinil eter) \\
\hline PTFE & poli(tetrafluoroetileno) \\
\hline PE & polietileno \\
\hline PP & polipropileno \\
\hline AMS & $\alpha$-metil-estireno \\
\hline STY & estireno \\
\hline DVB & divinilbenzeno \\
\hline PTFE- $g$-PS & poliestireno enxertado no PTFE \\
\hline PTFE-g-AMS/STY & poliestireno e $\alpha$-metil-estireno enxertados no PTFE \\
\hline PTFE-g-S/DVB & $\begin{array}{l}\text { poliestireno enxertado no PTFE e reticulado com } \\
\text { divinilbenzeno }\end{array}$ \\
\hline RX-PTFE & PTFE reticulado \\
\hline c-PTFE & PTFE reticulado \\
\hline MEA & $\begin{array}{l}\text { membrane-electrode-assembly, conjunto eletrodo eletrólito } \\
\text { eletrodo }\end{array}$ \\
\hline TG & termogravimetria \\
\hline DSC & calorimetria exploratória diferencial \\
\hline FTIR & espectroscopia no infravermelho \\
\hline
\end{tabular}




\section{LISTA DE ABREVIAÇÕES}

MEV

DOG

IEC

$\mathrm{w}_{\mathrm{c}}$

$\Delta \mathrm{H}_{\mathrm{f}}$

$\Delta \mathrm{H}_{\mathrm{f} 100}$

$T_{\text {onset }}$ microscopia eletrônica de varredura

do inglês degree of grafting, grau de enxertia

do inglês íon exchange capacity, capacidade de troca iônica

grau de cristalinidade

variação da entalpia de fusão

entalpia de fusão do polímero $100 \%$ cristalino

Temperatura de início da decomposição térmica 


\section{INTRODUÇÃO}

A célula a combustível de baixa temperatura é hoje uma das principais fontes de pesquisa mundial em energia alternativa, destacando-se por seu caráter ambiental e sua alta eficiência energética.

A importância da célula a combustível está na sua alta eficiência e na ausência de emissão de poluentes, além de ser silenciosa. O seu principal combustível, o hidrogênio, pode ser obtido a partir de diversas fontes renováveis. Pesquisa e desenvolvimento de célula a combustível são realizados em todo o mundo com o objetivo de diminuir os custos, as dimensões e a dependência de combustíveis fósseis e, também, de aumentar a eficiência destes equipamentos. Uma das tecnologias mais pesquisadas atualmente é a célula a combustível de membrana trocadora de prótons (PEMFC do inglês proton exchange membrane fuel cell) $[1,2]$.

Na célula a combustível do tipo PEM o eletrólito é uma fina membrana sólida de polímero orgânico poli (ácido perfluorsulfônico), geralmente o Nafion ${ }^{\circledR}$, que é permeável aos prótons e não conduz elétrons. $O$ Nafion ${ }^{\circledR}$ é produzido pela Dupont e possui alta estabilidade química e mecânica, porém, seu processo de preparação é longo e de custo elevado o que motivou estudos para obtenção de novos tipos de membranas trocadoras de prótons.

Os fluoropolímeros constituem uma classe de polímeros com excelentes propriedades físicas e químicas. Tais propriedades são atribuídas à forte ligação carbono-flúor. Além disso, os átomos de flúor por apresentarem 
grande tamanho podem proteger a cadeia carbônica de polímeros, como o poli(tetrafluoroetileno) (PTFE), de ataque químico.

A enxertia induzida por radiação é um método versátil para a modificação de polímeros tanto que, fluoropolímeros que são altamente resistentes podem ser facilmente modificados pelo uso da radiação produzindo membranas com bom desempenho em célula [3].

Devido à estabilidade química necessária nas PEMFCs, estas membranas são comumente preparadas pelo processo de enxertia de estireno ou seus derivados induzida por radiação ionizante. São vários os polímeros fluorados estudados, tais como poli(tetrafluoroetileno-co-hexafluoropropileno) (FEP), poli(etileno-co-tetrafluoroetileno) (ETFE), poli(fluoreto de vinilideno) (PVDF), poli(tetrafluoroetileno-co-perfluoro alquil vinil eter) (PFA) e poli(tetrafluoroetileno) (PTFE) [3-18].

Os parâmetros que afetam a preparação das membranas trocadoras de prótons podem ser divididos em relação: à radiação e à mistura para enxertia. Os parâmetros relacionados à radiação incluem a natureza da radiação, a taxa de dose e a dose de irradiação. Nos parâmetros relacionados à mistura para a enxertia pode-se destacar a natureza do monômero e do filme, a concentração do monômero, o solvente, o agente reticulador, etc.

A técnica de enxertia de estireno e subseqüente sulfonação é estudada por muitos grupos de pesquisa. Um destes grupos é o do Paul Scherrer Institute (PSI) na Suíça. SCHERER et. al, estudaram filmes fluorados, como por exemplo o FEP, adaptados a célula a combustível [3-9].

Os processos de enxertia do estireno nos fluoropolímeros são usualmente conduzidos a temperaturas acima de $50{ }^{\circ} \mathrm{C}[1,3-17]$ e outro estudo relata que enxertias a temperatura ambiente não são observadas [18]. Um estudo comparativo da enxertia de estireno a temperatura ambiente após a irradiação simultânea, nas doses de 20 a 100 kGy, e em condições de pós irradiação (ou seja, num período de reação de enxertia de 7 a 28 dias após o processo de irradiação) usando diferentes solventes foi desenvolvido na tentativa de aumentar 
o grau de enxertia, e como conseqüência, o grau de sulfonação para melhorar a condutividade protônica na célula. É importante destacar como originalidade do tema que não se tem conhecimento na literatura de um estudo comparativo da enxertia de estireno a temperatura ambiente após irradiação simultânea em condições de pós irradiação, usando diferentes solventes.

O presente trabalho insere-se no âmbito das atividades de tecnologia de polímeros desenvolvidas pelo programa célula a combustível do IPEN. O coração da célula é o MEA (membrane-electrodes-assembly, conjunto eletrodos, membrana) cujo eletrólito é constituído por $\mathrm{Nafion}^{\circledR}$, ou produtos semelhantes, a um preço elevado. É um projeto pioneiro devido à não existência no Instituto de estudos referentes a membranas fluoradas enxertadas com estireno que possam substituir o Nafion ${ }^{\circledR}$.

Neste trabalho foram obtidas membranas poliméricas fluoradas, com propriedade de troca iônica para aplicação em célula a combustível. Os filmes de PTFE, PVDF, ETFE, FEP e PFA foram enxertados com estireno a temperatura ambiente, via irradiação. O método utilizado para enxertia foi o da irradiação simultânea em uma fonte de cobalto-60. Posteriormente os filmes enxertados foram sulfonados. Os filmes puros, enxertados e sulfonados foram caracterizados pelas técnicas de termogravimetria (TG), calorimetria exploratória diferencial (DSC), espectroscopia no infravermelho (MID-FTIR) e microscopia eletrônica de varredura (MEV), além do cálculo do grau de enxertia (DOG do inglês degree of grafting) por gravimetria. A capacidade de troca iônica (IEC do inglês íon exchange capacity) das membranas preparadas foi também determinada. As membranas foram por fim testadas na estação de testes para célula a combustível do $\mathrm{CCCH}$ (Centro de Célula a Combustível e Hidrogênio) obtendo-se as curvas de polarização de estado estacionário, para as reações simultâneas de redução de oxigênio e oxidação de hidrogênio, e posteriormente, comparadas ao Nafion ${ }^{\circledR}$. 


\section{OBJETIVO}

O objetivo do presente trabalho foi desenvolver o processo de produção de membranas poliméricas fluoradas condutoras, obtidas por meio da enxertia de estireno, a temperatura ambiente, induzida por radiação gama, em filmes fluorados listados na TAB. 1. As membranas preparadas quando comparadas ao Nafion $^{\circledR}$, devem apresentar baixa difusão de gases e propriedades de troca iônica, para serem aplicadas em célula a combustível de baixa temperatura de operação.

TABELA 1 Fluoropolímeros estudados

\begin{tabular}{l|c|c}
\hline \multicolumn{1}{c|}{ Nome } & Abreviação & Estrutura \\
\hline Poli(tetrafluoroetileno) & PTFE & $-\left[\mathrm{CF}_{2}-\mathrm{CF}_{2}\right]_{\mathrm{n}^{-}}$ \\
\hline Poli(fluoreto de vinilideno) & PVDF & $-\left[\mathrm{CH}_{2}-\mathrm{CF}_{2}\right]_{\mathrm{n}^{-}}$ \\
\hline $\begin{array}{l}\text { Poli(tetrafluoroetileno-co- } \\
\text { hexafluoropropileno) }\end{array}$ & FEP & $-\left[\mathrm{CF}_{2}-\mathrm{CF}_{2}\right]_{\mathrm{n}}-\left[\mathrm{CF}_{2}-\mathrm{CF}-\left(\mathrm{CF}_{3}\right)_{\mathrm{m}^{-}}\right.$ \\
\hline $\begin{array}{l}\text { Poli(etileno-co- } \\
\text { tetrafluoroetileno) }\end{array}$ & ETFE & $-\left[\mathrm{CF}_{2}-\mathrm{CF}_{2}\right]_{\mathrm{n}}-\left[\mathrm{CH}_{2}-\mathrm{CH}_{2}\right]_{\mathrm{m}}{ }^{-}$ \\
\hline $\begin{array}{l}\text { Poli(tetrafluoroetileno-co- } \\
\text { perfluoro alquil vinil eter) }\end{array}$ & PFA & $-\left[\mathrm{CF}_{2}-\mathrm{CF}_{2}\right]_{n}-\left[\mathrm{CF}_{2}-\mathrm{CF}-\left(\mathrm{OC}_{3} \mathrm{~F}_{7}\right)\right]_{\mathrm{m}^{-}}$ \\
\hline
\end{tabular}




\section{FUNDAMENTOS TEÓRICOS}

\subsection{Célula a combustível}

As células a combustível são células galvânicas que convertem energia química diretamente em energia elétrica e calor.

Os principais tipos de células a combustível estudados atualmente são classificados de acordo com o eletrólito utilizado e a temperatura de operação [19]:

- Célula a combustível de membrana de troca protônica (PEMFC - Proton Exchange Membrane Fuel Cell) e célula a combustível de metanol direto (DMFC - Direct Methanol Fuel Cell);

- Célula a combustível alcalina (AFC - Alkaline Fuel Cell);

- Célula a combustível de ácido fosfórico (PAFC - Phosforic Acid Fuel Cell);

- Célula a combustível de carbonatos fundidos (MCFC - Molten Carbonate Fuel Cell);

- Célula a combustível de óxido sólido (SOFC - Solid Oxide Fuel Cell).

Dentre os tipos de célula a combustível apresentados, atenção tem sido dada as do tipo PEM, na qual a membrana tem como funções ser o eletrólito e uma barreira física entre o cátodo e o ânodo. 
Uma célula tipo PEM combina um combustível (hidrogênio) e um oxidante (oxigênio) e, com ajuda de um eletrocatalisador (platina), produz corrente elétrica, água e calor com a vantagem de não gerar poluentes. Os eletrodos são compostos por duas camadas funcionais distintas, a camada difusora de tecido de carbono e a camada catalítica composta de platina suportada em carbono. A camada difusora tem como funções distribuir o gás reagente, facilitar a remoção dos produtos e conectar eletricamente a camada catalisadora aos circuitos elétricos externos, atuando também como um suporte mecânico do eletrodo. A camada catalisadora tem como função promover a reação eletroquímica e está ligada ao eletrólito polimérico condutor de prótons. Por trás, os eletrodos porosos estão em contato com placas que contém canais através dos quais um combustível gasoso é distribuído ao ânodo e um gás oxidante é distribuído ao cátodo (FIG 1) [20].

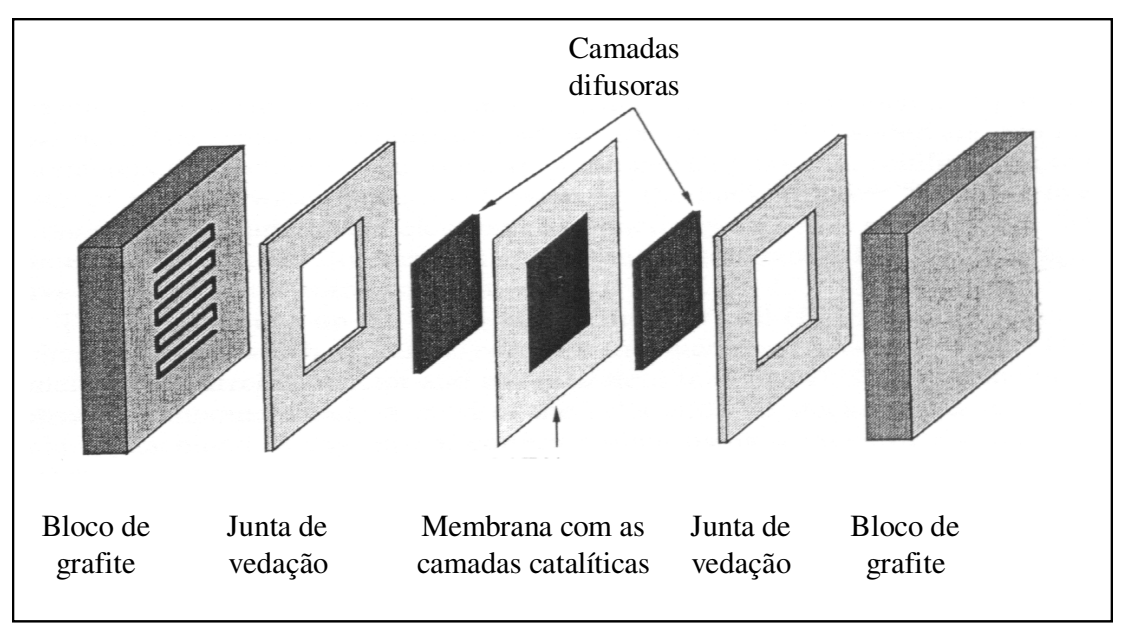

FIGURA 1: Componentes de uma célula PEM unitária [20].

As reações básicas nestas células são as duas semi-reações (1 e 2) e a reação total (3) apresentadas a seguir que acontecem nos eletrodos.

O gás hidrogênio é cataliticamente dissociado no ânodo formando os íons $\mathrm{H}_{3} \mathrm{O}^{+}$e liberando elétrons de acordo com a reação (1):

$$
\mathrm{H}_{2}+2 \mathrm{H}_{2} \mathrm{O} \rightarrow 2 \mathrm{H}_{3} \mathrm{O}^{+}+2 \mathrm{e}^{-}
$$


Os elétrons liberados são conduzidos através de um circuito elétrico externo até o cátodo, originando uma corrente elétrica contínua. Os íons produzidos na reação anódica são transferidos para o cátodo através do eletrólito, onde são combinados cataliticamente com o oxigênio formando água de acordo com a reação (2):

$$
1 / 2 \mathrm{O}_{2}+2 \mathrm{H}_{3} \mathrm{O}^{+}+2 \mathrm{e}^{-} \rightarrow 3 \mathrm{H}_{2} \mathrm{O}
$$

A reação global, que é acompanhada de liberação de calor, pode ser escrita de acordo com a reação (3):

$$
\mathrm{H}_{2}+1 / 2 \mathrm{O}_{2}+2 \mathrm{H}_{2} \mathrm{O} \rightarrow 3 \mathrm{H}_{2} \mathrm{O}
$$

Um esquema simplificado de uma célula a combustível tipo PEM é apresentado na FIG. 2. Os prótons produzidos na reação anódica são conduzidos pelo eletrólito até o cátodo, onde se combinam com o produto da redução do oxigênio, formando água.

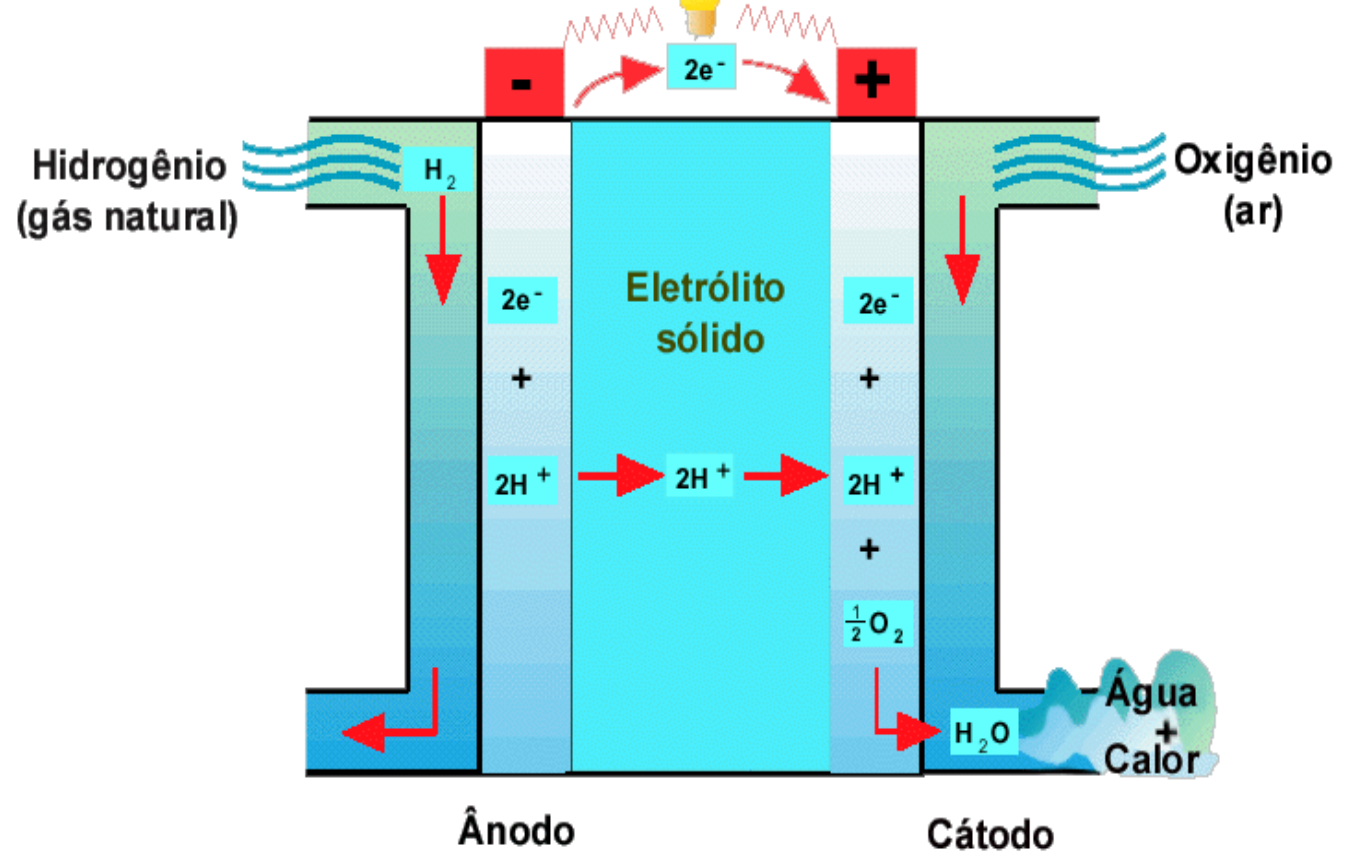

FIGURA 2: Desenho esquemático de uma célula a combustível. 
A membrana transporta íons formados no ânodo para o cátodo permitindo o escoamento da corrente pela célula [1]. Nestas células, o eletrólito é uma membrana de polímero condutor protônico sólido, que, quando hidratada, passa a conduzir os íons $\mathrm{H}_{3} \mathrm{O}^{+}$sob o efeito de uma diferença de potencial.

Os requisitos necessários $[4,10]$ para que uma membrana polimérica seja aplicável à célula a combustível incluem:

- Boa condutividade protônica;

- Estabilidade química;

- Estabilidade térmica;

- Propriedades mecânicas (resistência, flexibilidade e processabilidade);

- Baixa permeabilidade a gás;

- Baixo custo e disponibilidade.

O Nafion ${ }^{\circledR}$ é o material usado na PEM por causa de sua alta estabilidade química. De uma forma geral, existe uma fase hidrofóbica, que corresponde à cadeia principal de politetrafluoroetileno (PTFE) e uma fase hidrofílica composta por cadeias laterais éter vinila com íons sulfônicos $\left(\mathrm{SO}_{3}{ }^{-}\right)$ terminais. Este polímero possui baixa cristalinidade devido ao grande número de grupos laterais, sendo que o PTFE contribui com a parte cristalina e as cadeias sulfonadas com a parte amorfa [21]. A estrutura da membrana Nafion ${ }^{\circledR}$ é representada por:

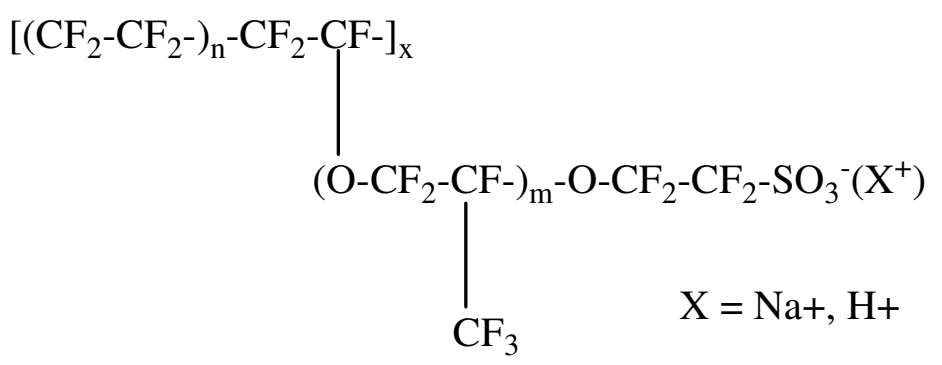


sendo: $n=5$ a $13 ; x » 1000$ e $m » 1$. As pontas das cadeias, em que se encontram os grupos sulfônicos formam uma espécie de aglomerado na estrutura, que se incha em contato com a água ou o vapor d'água. Estes aglomerados, que são interligados, são responsáveis pela condução dos prótons da água pela membrana sob o efeito de uma diferença de potencial. Manter o balanceamento de água na célula é extremamente importante, pois a condutividade protônica da membrana é fortemente dependente deste fator [19].

\subsubsection{Curva de polarização}

A curva que caracteriza o desempenho das células a combustível é denominada de curva de polarização [19,20]. Numa curva de polarização é efetuado o levantamento das diferenças de potencial geradas por uma célula para diferentes valores de correntes. Tais curvas representam as características da corrente e da voltagem das reações eletroquímicas que ocorrem nos MEA's. $O$ desempenho do MEA depende de fatores como o tipo de membrana utilizada, a estrutura dos eletrodos, o tipo de combustível e do oxidante usados, a pressão dos gases, a temperatura operacional da célula e a umidade dos locais onde ocorrem as reações. A FIG. 3 mostra o esboço de uma curva de polarização na qual estão representados os três principais tipos de polarização.

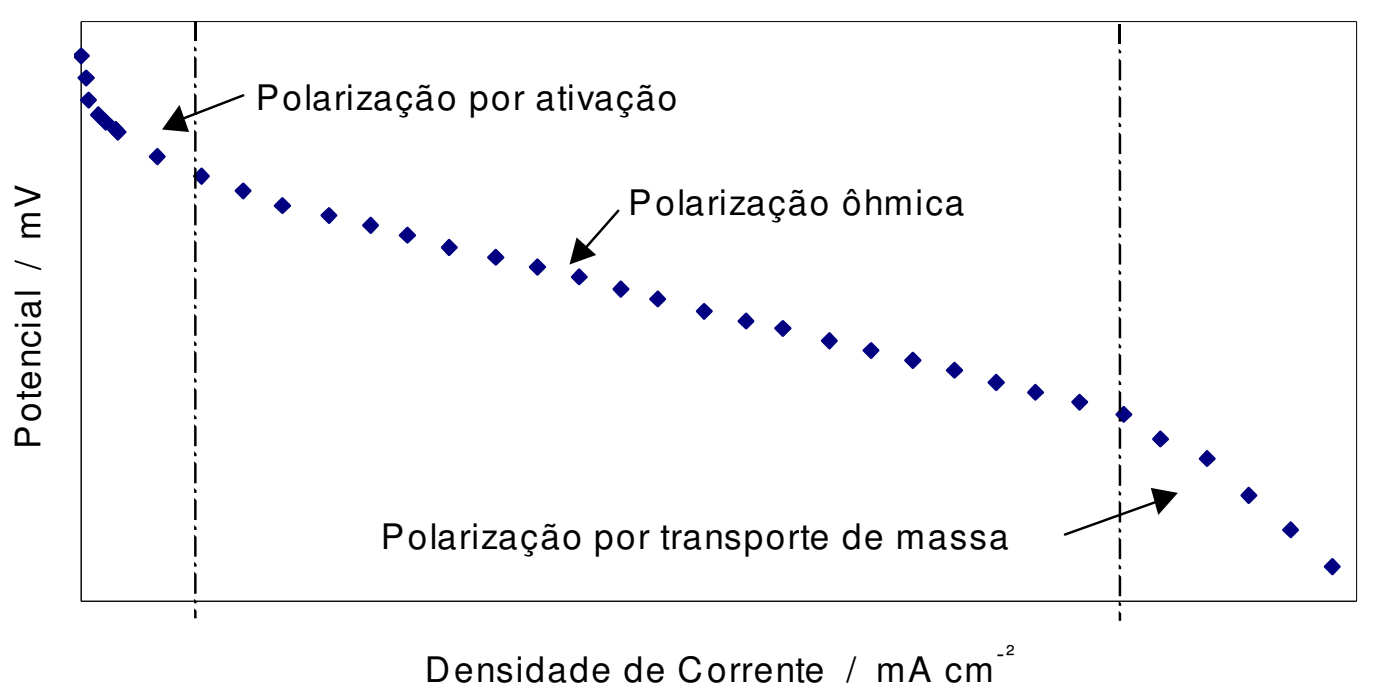

FIGURA 3: Esboço de uma curva de polarização. 
Na FIG. 3 podem ser observadas três regiões distintas de polarização:

- Polarização por ativação: em baixas densidades de corrente, com queda acentuada de potencial, é determinada por transferência de cargas (queda exponencial). A região determinada por transferência de cargas é devida, principalmente, a reação de redução de oxigênio, que a baixa temperatura é fortemente cineticamente desfavorecida. Os processos eletroquímicos que contribuem para as perdas de ativação são complexos e envolvem a absorção das espécies reagentes, a transferência dos elétrons através da dupla camada da célula, a desorção das espécies produzidas e a natureza da superfície do eletrodo.

- Polarização ôhmica: região com queda de potencial linear que é devida a resistência ao fluxo de íons no eletrólito e à resistência do fluxo dos elétrons através do eletrodo.

- Polarização por transporte de massa: ocorre em altas densidades de corrente, é determinada pelo esgotamento da espécie reagente na superfície ativa e identificada pela queda acentuada no final da reta.

\subsection{Processamento por radiação}

O processamento por radiação é uma técnica bastante eficaz de melhoria das qualidades finais de uso de vários polímeros. Este é um método bem estabelecido de modificações precisas de propriedades de inchamento de resinas e componentes poliméricos. Propriedades importantes, tais como mecânica, estabilidade térmica, resistência química, processabilidade e de superfície podem ser significativamente melhoradas por este processamento.

Aplicações práticas para o processamento de materiais por radiação têm sido realizadas há mais de 50 anos. Quando estas radiações interagem com o material polimérico, sua energia é absorvida por ele e ativam espécies, radicais são produzidos, iniciando várias reações químicas nas vizinhanças. Os radicais 
são gerados na região amorfa e na região cristalina do polímero. Os radicais da fase amorfa podem reagir entre si e com o monômero (no caso de reações de enxertia induzida pela radiação ionizante).

Há três processos fundamentais que são os resultados destas reações:

Reticulação - as cadeias poliméricas são ligadas e é formada uma rede;

Decomposição - a massa molar do polímero é reduzida devido à cisão (quebra) de cadeias;

Enxertia - um monômero é polimerizado e enxertado na cadeia polimérica.

Quando os monômeros são irradiados, a sua polimerização também pode ser iniciada. Todos estes processos induzidos por radiação têm encontrado muitas aplicações úteis em materiais plásticos e borrachas.

Para aplicações da tecnologia de radiações, as principais fontes incluem raios gama do ${ }^{60} \mathrm{Co}$, feixes de elétrons de aceleradores de partículas e raios- $X$ convertidos de feixes de elétrons $[22,23]$.

O processamento por radiação de materiais poliméricos envolve a exposição de polímeros à irradiação, geralmente de modo contínuo para modificações industriais. Raios gama e feixe de elétrons são comumente empregados para iniciar a enxertia.

A enxertia induzida por radiação é conhecida como um método eficaz para modificação de superfícies de materiais poliméricos. As propriedades da superfície de polímeros podem ser modificadas pela copolimerização com diferentes monômeros. Este processo pode ser feito pela irradiação sobre polímeros comuns, como polietileno (PE), polipropileno (PP) e polímeros fluorados. Uma das aplicações destas membranas poliméricas modificadas pelo uso da radiação é em célula a combustível. Membranas trocadoras de íons e filmes separadores de célula a combustível podem ser feitos em matrizes de polímeros fluorados por enxertia de estireno seguida de sulfonação. 
Há três métodos [22, 23] para a enxertia induzida pela radiação que estão ilustrados na FIG. 4.

O primeiro é o método da pré irradiação: o polímero é irradiado sob vácuo ou atmosfera inerte para gerar os radicais e, posteriormente, o monômero de estireno é adicionado para efetuar a enxertia. O segundo método é a irradiação simultânea: o polímero é imerso em uma solução contendo o monômero de estireno e ambos são irradiados. O terceiro método é o da peroxi/hidroperoxidação: o polímero é exposto à radiação na presença de ar ou oxigênio, os radicais peroxila ou grupos hidroperóxidos são produzidos no polímero e, posteriormente, é imerso no monômero iniciando a reação de enxertia. 

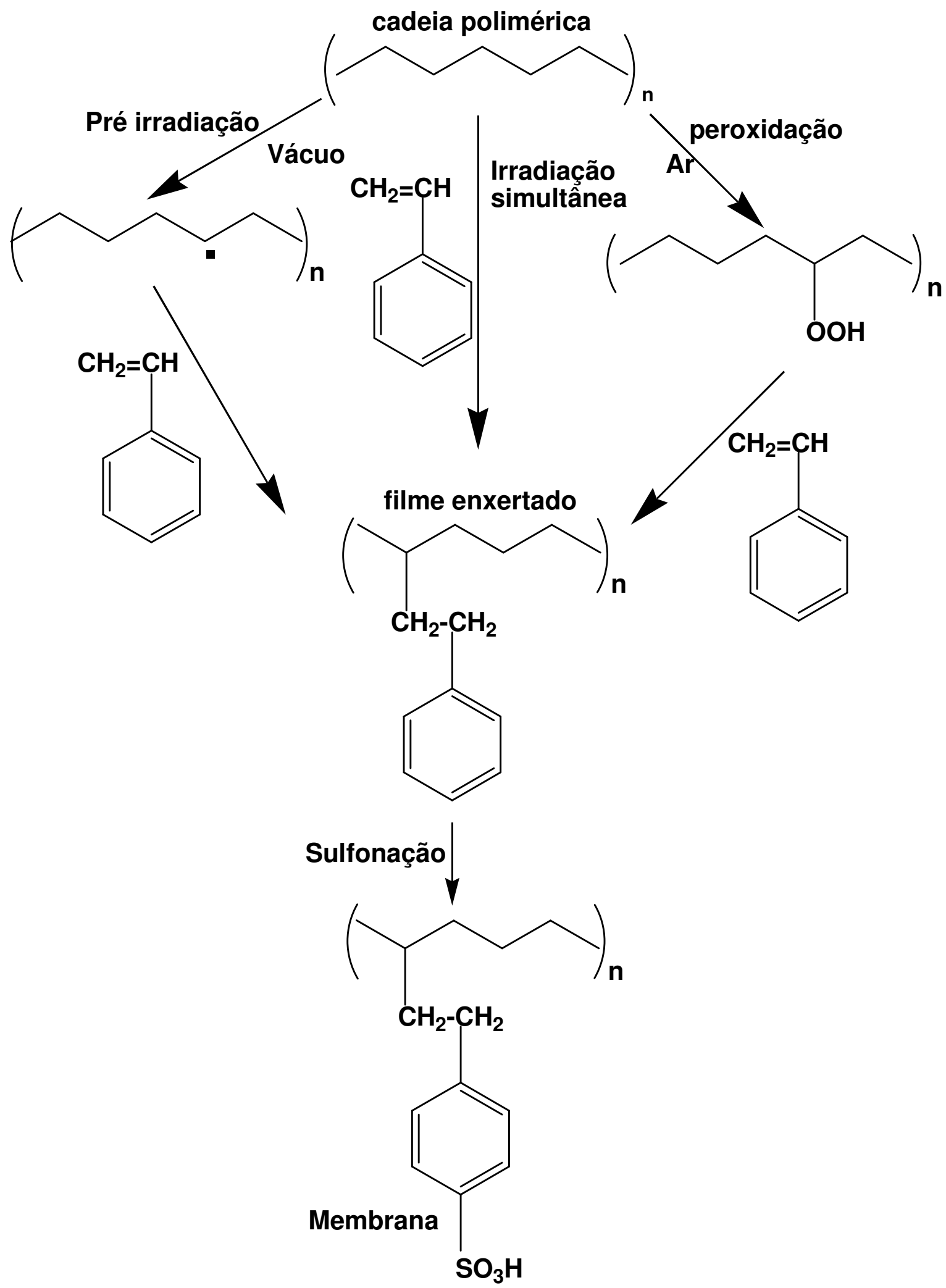

FIGURA 4: Rotas de preparação para filmes enxertados e sulfonados. 


\subsection{Filmes poliméricos para enxertia}

Há muitos polímeros que podem ser usados como base para enxertia: os perfluorados (totalmente fluorado) como o PTFE, PFA e o FEP, os parcialmente fluorados como o PVDF e o ETFE e os hidrocarbonetos como PP e PE.

Os fluoropolímeros encontram-se entre a maioria dos polímeros inertes quimicamente e permanecem estáveis em quase todos os ambientes químicos. Tais propriedades de alto desempenho são o resultado da estrutura química única dos fluoropolímeros, que difere significativamente da estrutura dos polímeros tradicionais como o polietileno. A compreensão da estrutura química oferece um melhor entendimento da razão pela qual os fluoropolímeros possuem tal resistência química excepcional (e outras propriedades). O PTFE é um homopolímero. Outro tipo de homopolímero da família do fluoropolímero é o PVDF. Em certos casos são unidos dois diferentes tipos de meros (partes de um polímero) para formar um copolímero que possui estrutura linear ou uma estrutura enxertada (um copolímero de enxertia). Os copolímeros são amplamente utilizados na família do fluoropolímero, por exemplo: o FEP que é um copolímero do tetrafluoroetileno e do hexafluoropropileno, o ETFE que é um copolímero de etileno e tetrafluoroetileno e o PFA que é um tipo especial de copolímero no qual os meros não são adicionados na mesma proporção.

Há vários trabalhos publicados internacionalmente, que fizeram uso do processo de enxertia induzida por radiação, para aplicação em membranas.

O PTFE é o filme mais utilizado comercialmente por sua estabilidade química e térmica excepcionais. Muitos esforços foram concentrados no sentido de se preparar membranas de PTFE [24]. No entanto, suas aplicações são limitadas devido a sua degradação quando submetido a radiações de alta energia [25]. Até o momento, o desempenho em células a combustível contendo membranas de PTFE enxertadas via irradiação é raramente reportado. No entanto, os filmes de PTFE podem ser reticulados via irradiação na ausência de oxigênio e a uma temperatura próxima à de sua fusão. Com isso, os filmes reticulados (c-PTFE $-c$ do inglês crosslinked) tornam-se mais estáveis à 
irradiação e resistem melhor à enxertia com estireno que os filmes não reticulados. O interesse no uso de filmes c-PTFE aplicáveis em células a combustível tem atraído atenção principalmente dos pesquisadores japoneses [24-29].

LI et. al. estudaram PTFE-g-PS (enxertia do poliestireno) e PTFE- $g$ AMS/STY (enxertia do $\alpha$-metil-estireno/estireno) ou PTFE- $g$-S/DVB (estireno/divinilbenzeno) em membranas de PTFE reticulado (RX-PTFE) e, posteriormente, sulfonadas [10,14-17].

TABATA et al. [29] pesquisaram a reticulação e enxertia de PTFE induzidas por radiação. Eles verificaram que a reticulação de PTFE pode ser formada não somente pela irradiação no estado fundido, mas também por enxertia múltipla (passo a passo) do monômero em PTFE. O PTFE reticulado mostrou melhorias consideráveis na resistência à radiação, bem como melhorias nas propriedades mecânicas. Os filmes irradiados foram comparados aos do PTFE não reticulado.

SATO et al. [27] processaram membranas para células a combustível baseado em filmes de PTFE reticulados. A enxertia do estireno via raios $\gamma$ foi efetuada sob ar. As propriedades mecânicas foram perdidas com o aumento do grau de enxertia; especialmente a membrana com alto grau de enxertia que se apresentou frágil (quebradiça).

LAPPAN et al. [30] estudaram mudanças na estrutura química do PTFE induzidas por irradiações com feixes de elétrons em estado fundido. O PTFE foi exposto a radiação de feixe de elétron em temperaturas elevadas acima do ponto de fusão em atmosfera de nitrogênio e sob vácuo para comparação.

Os filmes de FEP e PFA apresentam maior resistência à irradiação, formando radicais mais estáveis possibilitando enxertias com vários monômeros diferentes. Há a possibilidade de se aplicar doses maiores de irradiação na preparação das membranas sem afetar significativamente as propriedades mecânicas. No grupo do Paul Scherrer Institute (PSI) na Suíça, SCHERER et. al., estudaram filmes fluorados como, por exemplo, o FEP adaptados a células a combustível [3-9, 31-33]. Os filmes de FEP foram irradiados por feixe de elétrons nas condições de pré irradiação ou irradiação simultânea e, em seguida, os 
grupos estirênicos foram enxertados em geral a temperaturas que variaram de 40 a $90{ }^{\circ} \mathrm{C}$. A condutividade protônica é introduzida pela sulfonação dos grupos arilo. O desempenho em célula das membranas de FEP foi satisfatório quando comparado ao das membranas Nafion ${ }^{\circledR}$ nas mesmas condições de operação.

BÜCHI et al. [31] prepararam membranas enxertadas via pré-irradiação a 60 kGy. Foram preparadas misturas estireno/divinilbenzeno e adicionadas aos frascos contendo filmes de FEP pré irradiados. Posteriormente os filmes enxertados foram sulfonados. A enxertia foi realizada expondo o filme em solução do monômero, em uma temperatura de $60{ }^{\circ} \mathrm{C}$. O divinilbenzeno foi usado como agente reticulante misturado com estireno na solução de enxertia. O grau de enxertia dos filmes foi determinado pelo aumento do peso molecular.

O polímero PFA foi estudado por NASEF et al. [34,35]. Eles concluíram que as membranas de PFA são promissoras para aplicação em célula devido à boa combinação entre as propriedades físico-química, estrutural e térmica.

DARGAVILLE et. al. [36] estudaram a enxertia no PFA em diclorometano, tolueno e metanol a diferentes concentrações de estireno. Maiores enxertias foram obtidas em diclorometano, seguido de tolueno e metanol a uma concentração de $60 \%(\mathrm{v} / \mathrm{v})$ de estireno.

PARK et al. [37] estudaram a enxertia de estireno e sulfonação em filmes de PFA nas doses de 50 a 200 kGy utilizando o método simultâneo. O grau de enxertia das membranas preparadas mostrou-se dependente da dose de irradiação. Foram obtidas membranas com alta capacidade de troca iônica (1,8 -

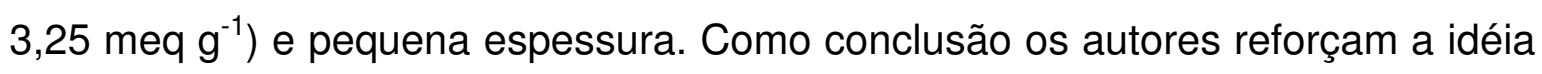
de que as membranas preparadas são promissoras candidatas a membranas de troca iônica para célula a combustível.

Os filmes parcialmente fluorados ETFE e PVDF cuja estrutura combina hidrocarbonetos e fluoro carbonos possuem alta resistência a irradiação e boas propriedades mecânicas. A estrutura parcialmente fluorada, abre a possibilidade de se enxertar tanto pelo método simultâneo quanto pelo método da pré irradiação [38, 39]. 
HORSFALL e LOVELL [40] estudaram amplamente uma série de polímeros (polietileno de alta e baixa densidade, ETFE, PFA, FEP, PTFE e PVDF) por diferentes métodos de irradiação, investigando a dose total de radiação, a taxa de dose, a concentração do monômero (20 a 70\% v/v de estireno em tolueno), a temperatura (40 a $70{ }^{\circ} \mathrm{C}$ ) e o tempo de reação (entre 3 e 24 horas). Para os estudos pelo método simultâneo, os parâmetros: dose total, taxa de dose e concentração do monômero são importantes. Nas investigações pelo método da pré irradiação a temperatura da reação é mais significativa.

Um estudo comparativo dos filmes PTFE, c-PTFE (PTFE reticulado), FEP, PFA, ETFE, PVDF e PVF (fluoreto de polivinil) foram efetuados por CHEN et al. [24]. Os resultados mostraram que os filmes de PTFE e PVF não são indicados para preparar membranas para célula a combustível por serem facilmente degradados pela radiação, sendo o PVF quimicamente instável. Os filmes de ETFE e PVDF são facilmente enxertados via radiação. A condutividade e absorção de água nas membranas de c-PTFE, FEP, PFA, ETFE e PVDF tiveram desempenho comparável às membranas Nafion ${ }^{\circledR}$. As membranas preparadas a partir dos filmes perfluorados mostraram maior estabilidade química que as membranas preparadas a partir dos filmes parcialmente fluorados. Todavia as membranas parcialmente fluoradas apresentam melhores propriedades mecânicas. Então, concluíram que as membranas perfluoradas são materiais promissores para célula a combustível alimentada com hidrogênio, pois é necessária longa durabilidade. As membranas parcialmente fluoradas são apropriadas para a célula a metanol devido a sua alta resistência mecânica e baixa permeabilidade ao combustível [24].

A influência da temperatura de reação na enxertia de estireno em filmes de ETFE foi estudada por GILMEAU et al. [41]. As temperaturas de reação na enxertia variaram de 50 a $80{ }^{\circ} \mathrm{C}$. Os filmes de ETFE foram pré irradiados na presença de ar e a temperatura ambiente. Posteriormente foi adicionada uma solução de estireno/etanol. Os tubos foram selados e submetidos à variação de temperatura. Foram verificados maiores rendimentos de enxertia à temperatura de $50{ }^{\circ} \mathrm{C}$. 
PVDF, ETFE e FEP foram estudados por BRACK et al. [42] Os filmes foram irradiados em feixe de elétrons e gama. Enxertias com valores bem próximos foram obtidas para os três filmes estudados, sendo que as amostras irradiadas em feixe de elétrons obtiveram valores pouco maiores. Os valores de temperatura de fusão dos filmes irradiados nos dois tipos de fonte foram similares aos dos filmes prístino.

O PVDF tem sido estudado enxertando-se grupos estirênicos [11-13]. A combinação entre boa estabilidade física e resistência química do PVDF aliada à boa condutividade decorrente da sulfonação do polímero fornece alta permeação a água [11, 43] e alta condutividade protônica [12, 44].

Membranas de PVDF foram preparadas também por MOKRINI e HUNEAULT [45] com blendas estireno-(etileno-butileno). KALLIO e colaboradores estudaram membranas de PVDF de diferentes espessuras enxertadas com estireno via radiação comparando-as ao Nafion $^{\circledR}[46]$.

O desempenho em célula a combustível das membranas enxertadas via irradiação e sulfonadas também é investigado em todo o mundo.

Grupos na Inglaterra [47], Itália [48] e Finlândia [49] investigam há muitos anos membranas de ETFE aplicadas em célula a combustível. Em testes com metanol como combustível, a DMFC, o desempenho foi superior quando comparadas as medidas com MEAs preparados com a membrana Nafion ${ }^{\circledR}$ 117. A durabilidade foi superior a $2000 \mathrm{~h}$ variando-se a temperatura de operação entre 30 e $85{ }^{\circ} \mathrm{C}[47,49]$. Também foram reportados na literatura estudos a alta temperatura $\left(110^{\circ} \mathrm{C}\right)$ com durabilidade de mais de um mês [48].

Filmes de PVDF podem também ser amplamente utilizados como polímero base para o preparo de membranas enxertadas via radiação. Isso é atribuído a sua alta resistência à fadiga, ao baixo custo e à formação de estruturas reticuladas via irradiação. As membranas de PVDF foram investigadas em detalhes por KALLIO et al. [50] em células alimentadas com metanol sendo de desempenho similar aos reportados para membranas de ETFE [49]. Eles também observaram que membranas com alta absorção de água tiveram durabilidade 
menor em testes na célula a combustível quando comparadas às membranas com baixa absorção de água [46].

No Japão, foram estudados filmes de ETFE enxertados com metil estireno, terc-butil estireno, divinilbenzeno e bis(p,p-vinil fenil)etano e subseqüente sulfonação. Tais membranas mostraram-se eficientes em células a metanol quando comparadas ao Nafion ${ }^{\circledR} 112[51,52]$.

No Paul Scherrer Institute (PSI) na Suíça foram estudadas membranas de FEP de diferentes espessuras, enxertadas com estireno e divinilbenzeno obtendo-se desempenho satisfatório durante o período de 100 a 2000 horas de operação [3].

\subsection{Efeito do solvente e sulfonação}

Geralmente a enxertia induzida por irradiação acontece em um sistema no qual o monômero é diluído em um solvente.

No mecanismo de enxertia, o solvente tem o papel de disponibilizar o monômero nas vizinhanças do polímero base. A escolha do solvente depende de vários parâmetros tais como a solubilidade do monômero no solvente as propriedades de inchamento do polímero base, a miscibilidade do solvente tanto com relação ao monômero quanto a outro solvente, usado em combinação para favorecer a enxertia, etc. O tipo de solvente e a mistura monômero/solvente podem influenciar a cinética de enxertia, o comprimento da cadeia de enxerto e a microestrutura polimérica (a morfologia da membrana). Benzeno, tolueno, diclorometano, alcoóis como o metanol, isopropanol ou etanol, são freqüentemente utilizados como solvente para a enxertia de estireno e seus derivados [53]. Isto porque os solventes podem intumescer o polímero permitindo que o monômero se difunda na matriz polimérica.

O efeito do solvente na preparação das membranas tem sido muito estudado [54]. A natureza do solvente determina o rendimento do grau de enxertia 
além de prever se a enxertia será mais penetrada no filme polimérico. Se o solvente intumesce pouco o filme, é mais provável que a velocidade de difusão do monômero diminua. Por outro lado, se um solvente com maior poder de intumescimento for usado, maiores rendimentos de enxertia serão obtidos e enxertias mais homogêneas serão verificadas. Isto é de particular interesse nas membranas de troca iônica já que uma distribuição de enxertos mais homogênea em todo o substrato é essencial para o transporte dos íons. O aumento do inchamento aumenta a difusão do monômero nas camadas mais internas do substrato polimérico e aumenta as interações dos sítios ativos mais internos com as moléculas de monômero, o que ocasiona uma enxertia homogênea.

NASEF et al. estudaram a influência dos solventes diclorometano, benzeno e metanol em filmes de PFA, PTFE e FEP utilizando o método de irradiação simultânea. As diluições do estireno por diclorometano favoreceram a enxertia. O poliestireno que é formado a partir da mistura de enxertia é mais solúvel neste solvente aumentando o grau de enxertia. Já em metanol o homopolímero formado é pouco solúvel aumentando a viscosidade da solução e impedindo o acesso do monômero aos sítios ativos, o que diminui o grau de enxertia. Eles concluíram que quanto maior a formação de homopolímero na mistura solvente/monômero menor o rendimento de enxertia [55-58].

WALSBY et al. [18] estudaram filmes de PVDF enxertados com estireno nos solventes tolueno e propanol, utilizando o método de pré-irradiação. Um maior rendimento de enxertia foi observado nos experimentos com propanol. O propanol favorece a alta concentração de monômero na zona de reação, o que leva a uma alta viscosidade da solução impedindo as terminações das cadeias e aumentando, portanto, o grau de enxertia. O estudo com tolueno mostrou que ele se difunde competitivamente com o estireno, favorecendo as terminações das cadeias enxertadas diminuindo, portanto, o grau de enxertia.

CARDONA et al. [59] estudaram a enxertia de estireno em filmes de PFA, utilizando o método de irradiação simultânea. $O$ mais eficiente em termos de aumento do grau de enxertia foi o diclorometano, seguido do benzeno e metanol. Observou-se alta difusividade do estireno nas soluções contendo diclorometano. 
O metanol causou rápida terminação do crescimento das cadeias de poliestireno desfavorecendo a enxertia. O metanol também induziu a redução da difusão do monômero durante a irradiação devido ao aumento da viscosidade da solução de enxertia, decorrente da insolubilidade do homopolímero poliestireno no metanol.

GERALDES et al. [60] estudaram a enxertia de estireno a temperatura ambiente em matrizes de PTFE e PVDF nos solventes tolueno e metanol. Foi determinado que, em solução de tolueno, há maior rendimento de enxertia nos filmes de PTFE enquanto que, para filmes de PVDF, o melhor solvente foi o metanol.

A condutividade protônica é inserida nos polímeros enxertados com estireno efetuando-se a sulfonação dos anéis aromáticos. Os grupos sulfônicos se dissociam na presença de água resultando na condução dos prótons, o que faz com que a membrana conduza íns. Os principais agentes sulfonantes para poliestireno incluem: ácido sulfúrico, tri-óxido de enxofre e ácido clorosulfônico.

O ácido clorosulfônico diluído com um solvente clorado (di ou tetracloroetano) é a rota de sulfonação mais utilizada para que os filmes enxertados se tornem membranas de condução protônica. Em geral, cada anel aromático sulfonado apresenta um grupo ácido clorosulfônico na posição para dirigente [18, 61]. FLINT [11], no entanto utiliza ácido sulfúrico concentrado para promover a sulfonação dos grupos estirênicos. 


\section{PARTE EXPERIMENTAL}

\subsection{Materiais}

Os filmes utilizados foram os comerciais PTFE, ETFE, PFA, FEP, Nafion ${ }^{\circledR}$ e o PVDF obtido por termoprensagem (TAB. 2).

TABELA 2 Procedência dos fluoropolímeros estudados.

\begin{tabular}{c|c|c|c}
\hline Nome & Abreviação & Espessura* & Procedência \\
\hline $\begin{array}{c}\text { Poli(tetrafluoroetileno) } \\
\text { vinilideno) }\end{array}$ & PTFE & 0,20 & Ultrahi plásticos \\
\hline $\begin{array}{c}\text { Poli(tetrafluoroetileno- } \\
\text { co- }\end{array}$ & PVDF & $0,12^{* *}$ & $\begin{array}{c}\text { Kynar 720 Arkema } \\
\text { Group }\end{array}$ \\
hexafluoropropileno) & FEP & 0,10 & Goodfellow \\
\hline $\begin{array}{c}\text { Poli(etileno-co- } \\
\text { tetrafluoroetileno) }\end{array}$ & ETFE & 0,125 & Goodfellow \\
\hline $\begin{array}{c}\text { Poli(tetrafluoroetileno- } \\
\text { co-perfluoro alquil vinil } \\
\text { eter) }\end{array}$ & PFA & 0,10 & Goodfellow \\
\hline $\begin{array}{c}\text { Nafion }{ }^{\circledR} 115 \text { e 117 } \\
{ }^{*} \text { mm; }{ }^{* *} \text { os filmes de PVDF foram obtidos por prensagem dos grãos. }\end{array}$ & \multicolumn{2}{|c}{ DuPont } \\
\hline
\end{tabular}

Os regentes e solventes empregados neste trabalho foram utilizados sem tratamento prévio. 
Estireno 99\% inibidor 4-tert-butilcatecol: Huntsman Ltda.

Tolueno PA 99,5\%: Merck.

Metanol PA 99,8\%: Merck.

Isopropanol PA 99,5\%: Merck.

Nitrogênio, grau de pureza 99,999\% com nível de oxigênio menor que 1 ppm: White Martins.

Ácido clorosulfônico PA 97\%: Acros Organic.

1,2-dicloroetano PA 99,0\%: Labsynth.

Cloreto de sódio PA 99,0\%: Vetec.

Hidróxido de sódio PA 97,0\%: Labsynth.

Ácido sulfúrico PA 99-95\%: Merck.

Ácido nítrico PA 65\%: Merck.

Água oxigenada 30\%: Merck.

Tecido de carbono (no wet proofing): Etek.

Negro de fumo Vulcan XC-72R: Cabot. 
Dispersão de Teflon® (PTFE - TE-306 60 \%): DuPont.

Eletrocatalisador (Pt/C, 20\%): Etek.

\subsection{Métodos}

\subsubsection{Enxertia dos filmes}

Para a enxertia, os filmes estudados foram cortados em tamanho $3 \mathrm{~cm}$ x $6 \mathrm{~cm}$, pesados, colocados em frascos de vidro que continha a solução de monômero de estireno diluído com tolueno, isopropanol ou metanol na proporção de 1:1 $\mathrm{v} / \mathrm{v}$. Após esta etapa, foi borbulhado nitrogênio $\left(\mathrm{N}_{2}\right)$ por cerca de 15 minutos, então os frascos foram vedados e enviados para irradiar sempre a temperatura ambiente (método de irradiação simultânea). Os filmes foram irradiados à temperatura ambiente num irradiador com fonte de ${ }^{60} \mathrm{Co}$ nas doses de 20, 40, 80 e 100 kGy a uma taxa de 5 kGy por hora. O irradiador está alocado na EMBRARAD/CBE (Empresa Brasileira de Irradiações). Ao término do processo de enxertia, que no presente trabalho foi monitorado nos períodos de 7, 14, 21 e 28 dias de pós-irradiação, os filmes foram submetidos a um tratamento térmico (4 horas a $70{ }^{\circ} \mathrm{C}$ sob vácuo) para promover a terminação das cadeias [62]. Em seguida, os filmes enxertados foram lavados com tolueno a quente em extrator Soxhlet por um período de 12 horas e secos a $70{ }^{\circ} \mathrm{C}$ em estufa a vácuo até peso constante. Os experimentos foram efetuados em triplicata.

\subsubsection{Sulfonação}

Para converter os filmes enxertados em membranas, estes foram imersos em uma solução de ácido clorosulfônico em 1,2-dicloroetano na proporção de 2:98 (v/v) por 3 , 4 e 5 horas a temperatura ambiente $[7,24]$. As membranas preparadas para as medidas em célula foram sulfonadas a 
concentração de 20:80 (v/v) [27]. Após o final de cada período de reação, as membranas foram lavadas em água destilada até pH neutro. [17, 37, 63-65].

\subsubsection{Preparo das membranas para confecção dos MEAs}

Para remover possíveis contaminantes orgânicos ou inorgânicos nas membranas para teste em célula a combustível foram efetuados procedimentos de preparo. As membranas modificadas por irradiação foram lavadas com ácido sulfúrico $0,5 \mathrm{~mol} \mathrm{~L}^{-1}$ por uma hora a $80{ }^{\circ} \mathrm{C}$. Posteriormente efetuaram-se 3 lavagens com água ultrapura a $70{ }^{\circ} \mathrm{C}$ por uma hora cada.

As membranas Nafion ${ }^{\circledR}$ foram tratadas em água ultrapura a $80{ }^{\circ} \mathrm{C}$ por uma hora e em seguida foram deixadas em água oxigenada $3 \%$ a $80{ }^{\circ} \mathrm{C}$ por uma hora. Novamente as membranas foram deixadas em água ultrapura a $80{ }^{\circ} \mathrm{C}$ por uma hora por três ciclos seguidos. Seguiu-se então uma lavagem com ácido sulfúrico $0,5 \mathrm{~mol} \mathrm{~L}^{-1}$ por uma hora a $80{ }^{\circ} \mathrm{C}$. Por fim, efetuaram-se 3 lavagens com água ultrapura a $80{ }^{\circ} \mathrm{C}$ por uma hora. As membranas foram guardadas imersas em água deionizada em frasco de vidro com tampa e adequadamente limpo (ausência de contaminantes orgânicos e inorgânicos).

\subsubsection{Preparo dos eletrodos}

Para as medidas de polarização em célula a combustível unitária, os eletrodos de difusão de gás foram formados por camada difusora e camada catalisadora independentes.

A camada difusora foi preparada pela deposição por filtração em ambas as faces de um substrato de tecido de carbono de uma mistura de pó de carbono e emulsão de Teflon®. Uma suspensão composta de PTFE e pó de carbono foi preparada e floculada ajustando-se o $\mathrm{pH}$ com ácido sulfúrico $0,5 \mathrm{~mol} \mathrm{~L}^{-1}$ para próximo de 3 . A solução foi então filtrada sobre as faces de tecido 
de carbono e espalhada com espátula de forma homogênea. A camada difusora foi então seca a $280{ }^{\circ} \mathrm{C}$ por 30 minutos e sinterizada a $330{ }^{\circ} \mathrm{C}$ por 30 minutos. Antes do uso o tecido de carbono foi termicamente tratado a $450{ }^{\circ} \mathrm{C}$ por 1 hora, seguido por um tratamento químico a $70{ }^{\circ} \mathrm{C}$ por uma hora com ácido nítrico a $25 \%$ em volume e lavado em água a $70{ }^{\circ} \mathrm{C}[66,67]$.

A camada catalisadora foi formada pela deposição por pincelagem de uma mistura de eletrocatalisador $\mathrm{Pt} / \mathrm{C} 20 \%$, isopropanol (solvente) e solução de Nafion ${ }^{\circledR}$ sobre uma das faces da camada difusora para a formação do ânodo e cátodo, com carga de $\mathrm{Pt}$ de $0,4 \mathrm{mg} \mathrm{cm}^{-2}$. O solvente foi evaporado lentamente e o material seco foi novamente disperso com isopropanol para formar a tinta a ser aplicada na camada difusora. Os catalisadores preparados foram então secos a $80{ }^{\circ} \mathrm{C}$ por 1 hora $[66,67]$.

\subsubsection{Preparo do conjunto membrana eletrodos}

Os conjuntos membrana-eletrodos (área geométrica de $5,0 \mathrm{~cm}^{2}$ ) foram preparados por meio da prensagem a quente do ânodo e cátodo às membranas desenvolvidas a temperatura de $125{ }^{\circ} \mathrm{C}$ e pressão de $1000 \mathrm{kgf} \mathrm{cm}^{-2}$ durante 2 minutos.

\subsection{Caracterização dos filmes e membranas}

As técnicas de caracterização dos filmes e membranas desenvolvidas foram efetuadas nos filmes prístino, enxertados e sulfonados. As técnicas usadas para a determinação da enxertia e sulfonação foram: determinação do grau de enxertia (DOG) via gravimetria; termogravimetria (TG); calorimetria exploratória diferencial (DSC); microscopia eletrônica de varredura (MEV); espectroscopia no infravermelho (FTIR-MID). As curvas de polarização também foram obtidas. 


\subsubsection{Grau de enxertia}

O grau de enxertia (degree of grafting, DOG) foi calculado segundo a equação (1) descrita a seguir.

$$
\% \mathrm{DOG}=\left[\left(\mathrm{m}_{\mathrm{f}}-\mathrm{m}_{\mathrm{i}}\right) / \mathrm{m}_{\mathrm{i}}\right] \times 100
$$

na qual $m_{i}$ é a massa inicial, $m_{f}$ a massa final após o enxerto ambas em gramas.

\subsubsection{Espectroscopia no infravermelho}

Os espectros de absorção na região do infravermelho dos filmes prístino e enxertados foram obtidos em um aparelho Nexus 670 FTIR da Thermo Nicolet na região de 400 a $4000 \mathrm{~cm}^{-1}$ alocado no Centro de Ciência dos Materiais (CCTM) do IPEN-CNEN/SP. Os filmes foram colocados diretamente no porta amostra e inseridos no aparelho para a obtenção do espectro.

\subsubsection{Microscopia eletrônica de varredura}

As microscopias eletrônicas de varredura (MEV) foram efetuadas em um microscópio Phillips XL 30 alocado no CCTM do IPEN-CNEN/SP. As amostras foram recobertas com ouro num Sputter Coater BAL - TEC SCD 050.

\subsubsection{Termogravimetria (TG)}

As curvas termogravimétricas foram obtidas utilizando-se uma termobalança TGA / SDTA 851 da Mettler-Toledo com razões de aquecimento em atmosfera dinâmica, de 25 a $750{ }^{\circ} \mathrm{C}$ a $10{ }^{\circ} \mathrm{C} \min ^{-1}$ sob atmosfera inerte. O aparelho está alocado no Centro de Química e Meio Ambiente (CQMA) do IPENCNEN/SP. As amostras foram pesadas entre 5 e $5,5 \mathrm{mg}$ e acondicionadas em 
cadinho de alumina. O gás nitrogênio utilizado nas análises possui grau de pureza de 99,999\% com nível de oxigênio menor que 1 ppm. Para a purga dos gases liberados na queima durante a análise foi utilizado o gás nitrogênio com grau de pureza 99,996\% com nível de oxigênio menor que 5 ppm.

\subsubsection{Calorimetria exploratória diferencial (DSC)}

As medidas de DSC foram obtidas no DSC 822 Mettler-Toledo sob atmosfera de nitrogênio na faixa de temperatura de 30 a $400{ }^{\circ} \mathrm{C}$, a $10{ }^{\circ} \mathrm{C}$ min $^{-1} \mathrm{O}$ aparelho está alocado no CQMA do IPEN-CNEN/SP. As amostras foram pesadas com 10 +/- 0,2 mg e acondicionadas em cadinhos de alumínio. O gás nitrogênio utilizado nas análises possui grau de pureza de 99,999\% com nível de oxigênio menor que $1 \mathrm{ppm}$. Para a purga dos gases liberados na queima durante a análise foi utilizado o gás nitrogênio com grau de pureza 99,996\% com nível de oxigênio menor que 5 ppm.

O grau de cristalinidade $\left(\mathrm{w}_{\mathrm{c}}\right)$ da matriz polimérica foi calculado segundo a equação (2).

$$
\mathrm{wc}=\left(\Delta \mathrm{H}_{\mathrm{f}} / \Delta \mathrm{H}_{\mathrm{f} 100}\right) \times 100
$$

onde $\Delta \mathrm{H}_{\mathrm{f}}$ é a variação da entalpia de fusão da amostra e $\Delta \mathrm{H}_{\mathrm{f} 100}$ é a entalpia de fusão do polímero $100 \%$ cristalino (TAB. 3).

TABELA 3: Valores da entalpia de fusão dos polímeros $100 \%$ cristalinos.

\begin{tabular}{c|c|c}
\hline Polímero & $\Delta \mathrm{H}_{\mathrm{f} 100}\left(\mathrm{~J} \mathrm{~g}^{-1}\right)$ & Ref. \\
\hline PVDF & 104,7 & 45 \\
\hline PTFE & 82,9 & 68 \\
\hline ETFE & 113,4 & 42 \\
\hline FEP & 87.9 & 42 \\
\hline PFA & 82,0 & 69 \\
\hline
\end{tabular}




\subsubsection{Cálculo da capacidade de troca iônica (IEC)}

Após a sulfonação foi obtida a capacidade de troca iônica das membranas pelo método da titulação de neutralização.

A capacidade de troca iônica (IEC do inglês íon exchange capacity) foi determinada mergulhando as membranas na forma ácida em uma solução $3 \mathrm{~mol}$ $\mathrm{L}^{-1}$ de $\mathrm{NaCl}$ por $15 \mathrm{~h}$ a temperatura ambiente. Os íons $\mathrm{H}^{+}$liberados na solução foram titulados com solução padrão de $\mathrm{NaOH} 0,05 \mathrm{~mol} \mathrm{~L}^{-1}$ até $\mathrm{pH}$ 7. A partir do volume de $\mathrm{NaOH}$ consumido na titulação foi calculado o IEC por unidade de massa $\left(\right.$ meq g $\left.^{-1}\right)$ da membrana seca.

Após a sulfonação, os grupos sulfônicos ligados ao estireno enxertado atuam como um condutor de prótons. Teoricamente, quando ocorre a reação de sulfonação, uma unidade de estireno deve conter um grupo sulfônico. Devido a isto, o valor do DOG tem relação direta com os valores da IEC. Esta relação é calculada pela equação (3)

$$
\mathrm{IEC}_{\mathrm{T}}=\left(1000 \times \mathrm{DOG} / \mathrm{M}_{\mathrm{est}}\right) /\left(100+\mathrm{DOG}+\left[\left(\mathrm{DOG} / \mathrm{M}_{\text {est }}\right) \times \mathrm{M}_{\text {sulf }}\right]\right) \mathrm{meq} \mathrm{g}^{-1} \quad \text { eq. (3) }
$$

onde a $M_{\text {est }}$ é a massa molar do estireno $\left(104 \mathrm{~g} \mathrm{~mol}^{-1}\right)$, $M_{\text {sulf }}$ é a massa molar do grupo sulfônico (80 $\left.\mathrm{g} \mathrm{mol}^{-1}\right)$ [26]. Simplificando a equação (3) temos a equação (4) que expressa o valor teórico da capacidade de troca iônica.

$$
\mathrm{IEC}_{\mathrm{T}}=(9,62 \times \mathrm{xDOG}) /(100+[1,77 \times \mathrm{xDOG}]) \mathrm{meq}^{-1}
$$

\subsubsection{Desempenho em célula}

Os testes de desempenho das membranas foram efetuados levantando-se as curvas de polarização do MEA (conjunto eletrodo-membrana). A estação de testes (FIG. 5) alocada no Centro de Célula a Combustível e Hidrogênio (CCCH) do IPEN-CNEN/SP consiste em um painel com controladores e indicadores de temperatura, pressão e vazão, um ou mais sistemas de 
umidificação para os gases reagentes e uma carga dinâmica. As curvas de polarização (em estado estacionário em células a combustível unitárias FIG 6 para verificar o desempenho das membranas irradiadas) foram obtidas galvanostaticamente, mantendo-se a célula a $80{ }^{\circ} \mathrm{C}$ e utilizando-se oxigênio saturado com água ultra-pura ( $>15 \mathrm{M} \Omega$, Millipore) a $85{ }^{\circ} \mathrm{C}$ e hidrogênio saturado em água ultra-pura a $95{ }^{\circ} \mathrm{C}$. Para a verificação da durabilidade das membranas irradiadas foram obtidas curvas de polarização em estado estacionário em células a combustível unitárias mantendo-se a célula a $80{ }^{\circ} \mathrm{C}$ e utilizando-se oxigênio seco a temperatura ambiente e hidrogênio saturado em água ultra-pura a $80{ }^{\circ} \mathrm{C}$ [11].

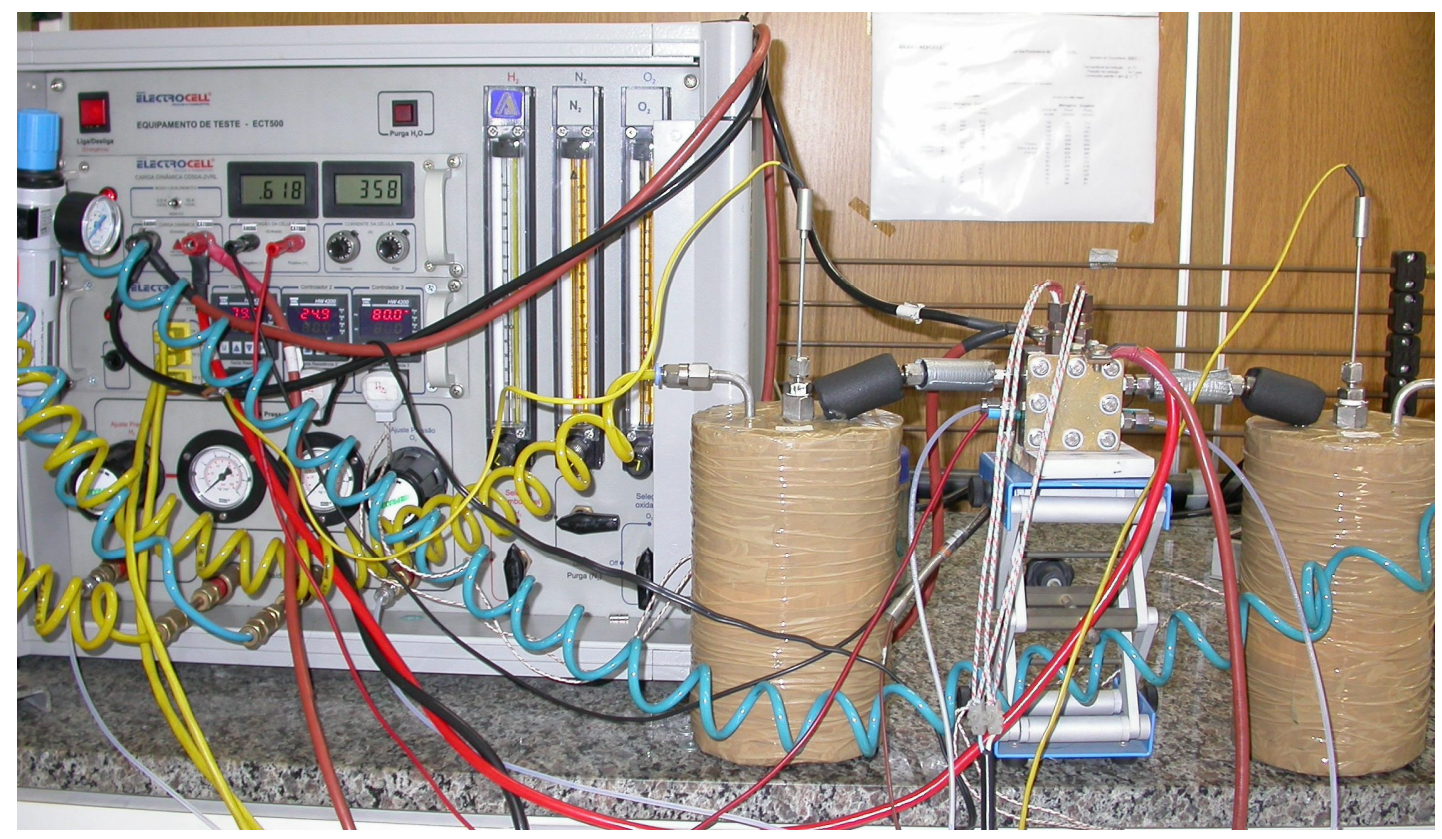

FIGURA 5: Estação de testes.
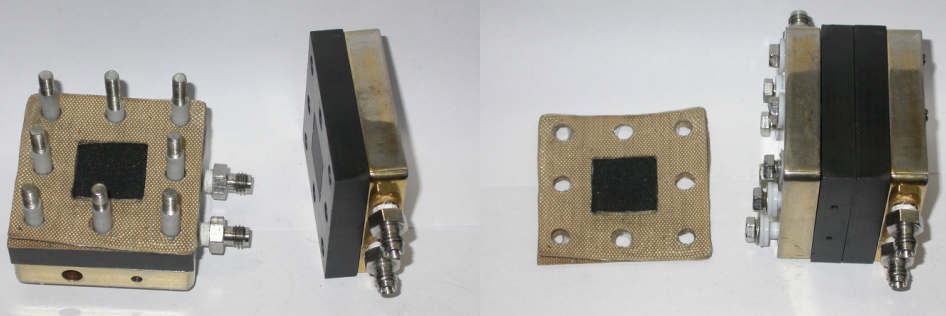

FIGURA 6: Célula a combustível de $5 \mathrm{~cm}^{2}$ aberta destacando-se o MEA. 


\section{RESULTADOS E DISCUSSÃO}

\subsection{Estabilidade dos filmes à radiação}

Os filmes fluorados foram irradiados com raios gama sob atmosfera inerte a 20,40, 80 e 100 kGy sem contato com a solução monomérica. Após a irradiação, os filmes foram submetidos a um tratamento térmico por 8 horas a 70 ${ }^{\circ} \mathrm{C}$ para promover as reações de terminação dos sítios ativos gerados pela radiação. Na seqüência os filmes foram caracterizados para verificar se a radiação provocou algum efeito nos filmes irradiados.

Pela técnica de espectroscopia no infravermelho (FTIR-MID) foram caracterizados os filmes de ETFE, FEP, PFA, PTFE e PVDF. Pode-se verificar por esta técnica que para todos os filmes estudados não houve aparecimento de bandas diferentes das já características dos fluoropolímeros. Na FIG 7, são apresentados os espectros no infravermelho dos filmes de ETFE e FEP prístino e irradiados.

As bandas características dos fluoropolímeros são: bandas intensas entre 1300 e $1100 \mathrm{~cm}^{-1}$ atribuídas à vibração do estiramento $\mathrm{CF}_{2}$; vibração do estiramento $\mathrm{CF}_{3}$ entre 943 e $982 \mathrm{~cm}^{-1}$. As bandas acima do número de onda 1300 $\mathrm{cm}^{-1}$ são bandas harmônicas e de combinação [26, 38, 51, 70]. Nos espectros dos filmes de ETFE (FIG 7 (a)) é possível identificar em $2976 \mathrm{~cm}^{-1}$ bandas atribuídas ao estiramento assimétrico $\mathrm{CH}_{2}$ e uma banda fina em $1450 \mathrm{~cm}^{-1}$ atribuída a deformação $\mathrm{CH}_{2}$. Nos espectros dos filmes de FEP (FIG 7 (b)) são verificadas as bandas atribuídas ao estiramento $\mathrm{CF}_{3}$. Nos espectros apresentados são visualizadas franjas de interferência indicando uma superfície plana nos filmes modificados. 
A extensão dos efeitos da radiação nos fluoropolímeros depende de vários fatores, tais como estrutura química, morfologia do polímero e condições da irradiação (atmosfera inerte ou presença de oxigênio). As reações mais comuns induzidas pela interação da radiação com os polímeros são cisão de cadeia, reticulação e formação de produtos voláteis [39]. Como observado por outros autores [39], os espectros dos filmes irradiados sob atmosfera inerte (FIG 7) não mostraram mudanças nas bandas de absorção quando comparados aos não irradiados.
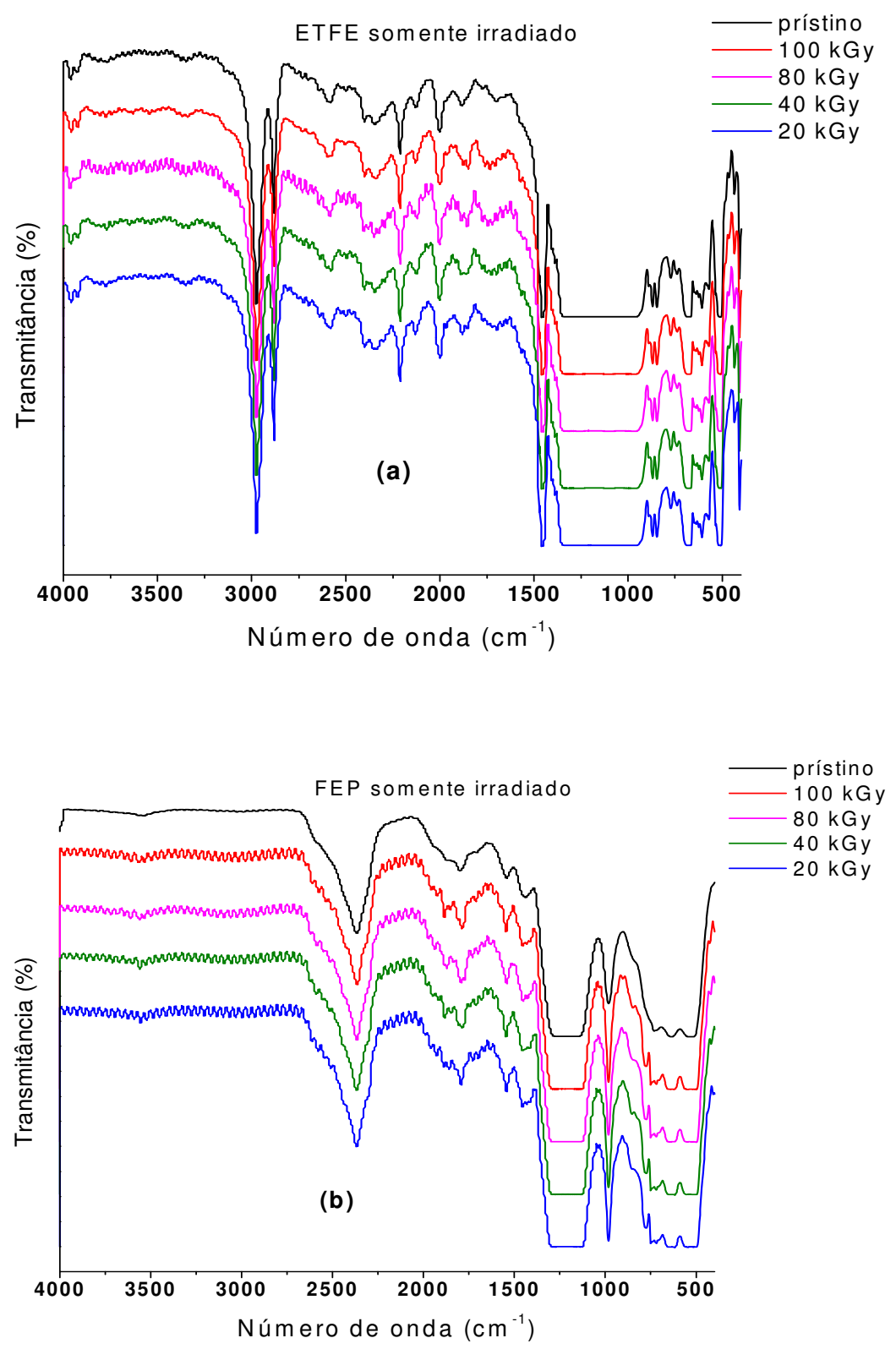

FIGURA 7: Espectros de infravermelho dos filmes ETFE (a) e FEP (b) prístino e expostos à radiação. 
$\mathrm{Na}$ TAB 4 são mostradas as temperaturas iniciais de decomposição ( Tonset $_{\text {) }}$ dos filmes ETFE, FEP, PFA, PTFE e PVDF prístino e irradiados.

TABELA 4: Valores de $T_{\text {onset }}$ obtidos por TG para os filmes de ETFE, FEP, PFA, PTFE e PVDF prístino e irradiados nas doses de 20, 40, 80 e 100 kGy.

\begin{tabular}{|c|c|c|}
\hline Filme & Dose (kGy) & $\mathrm{T}_{\text {onset }}\left({ }^{\circ} \mathrm{C}\right)$ \\
\hline ETFE $^{*}$ & - & 477 \\
\hline \multirow{4}{*}{ ETFE Irradiado } & 20 & 484 \\
\hline & 40 & 484 \\
\hline & 80 & 483 \\
\hline & 100 & 485 \\
\hline FEP $^{*}$ & - & 487 / 558 \\
\hline \multirow{4}{*}{ FEP Irradiado } & 20 & $483 / 565$ \\
\hline & 40 & $483 / 567$ \\
\hline & 80 & 482 / 565 \\
\hline & 100 & $481 / 565$ \\
\hline $\mathrm{PFA}^{*}$ & - & 524 \\
\hline \multirow{4}{*}{ PFA Irradiado } & 20 & 521 \\
\hline & 40 & 523 \\
\hline & 80 & 524 \\
\hline & 100 & 522 \\
\hline PTFE $^{*}$ & - & 555 \\
\hline \multirow{4}{*}{ PTFE Irradiado } & 20 & 551 \\
\hline & 40 & 558 \\
\hline & 80 & 557 \\
\hline & 100 & 556 \\
\hline PVDF* $^{*}$ & - & 437 \\
\hline \multirow{4}{*}{ PVDF Irradiado } & 20 & 437 \\
\hline & 40 & 436 \\
\hline & 80 & 433 \\
\hline & 100 & 436 \\
\hline
\end{tabular}

* prístino; $\mathrm{T}_{\text {onset: }}$ : temperatura inicial de decomposição; FEP apresenta duas $\mathrm{T}_{\text {onset }}$ : decomposição do copolímero hexafluoropropileno e decomposição da matriz polimérica.

Pela análise termogravimétrica dos filmes prístino e irradiados foi verificado que as temperaturas iniciais de decomposição dos filmes ETFE, FEP, 
PFA, PTFE e PVDF irradiados não foram significativamente alteradas. Os filmes de ETFE quando expostos à irradiação aumentaram em média $7{ }^{\circ} \mathrm{C}$ a $T_{\text {onset. }}$ Os filmes de FEP, PFA e PVDF quando irradiados tiveram ligeiro decréscimo na $T_{\text {onset. }}$.

Pelos resultados da análise de DSC (TAB 5) verifica-se que as temperaturas de fusão dos diferentes filmes irradiados não variaram quando comparado às dos filmes prístino.

Foram calculados o grau de cristalinidade pela equação 2. A cristalinidade dos polímeros ETFE, FEP PFA e PTFE aumentou quando os filmes foram expostos à radiação. Os polímeros sofrem somente cisão de cadeia quando irradiados abaixo da temperatura de fusão causando um aumento no alinhamento das cadeias com subseqüente aumento da cristalinidade [37] Já os filmes de PVDF tiveram comportamento contrário, com discreta diminuição do grau de cristalinidade que sugere a destruição da fase cristalina do polímero.

A cristalinidade dos filmes de PTFE após a exposição à radiação aumentou acima de $90 \%$. Como a enxertia ocorre na fase amorfa do polímero [42] é esperado que o rendimento de enxertia nestes filmes seja baixo. Há alguns artigos que sugerem que o grau de cristalinidade do PTFE aumente sob a irradiação e o grau de tal aumento varie com a dose [71], sendo o aumento da cristalinidade atribuído à cisão das cadeias na região amorfa [72,73]. 
TABELA 5: Valores obtidos na análise de DSC para os filmes de ETFE, FEP, PFA, PTFE e PVDF prístino e irradiados nas doses de 20, 40, 80 e 100 kGy.

\begin{tabular}{|c|c|c|c|c|}
\hline Filme & $\begin{array}{l}\text { Dose } \\
\text { (kGy) }\end{array}$ & $\mathrm{T}_{\mathrm{f}}\left({ }^{\circ} \mathrm{C}\right)$ & $\Delta \mathrm{H}_{\mathrm{f}}\left(\mathrm{J} \mathrm{g}^{-1}\right)$ & $\mathrm{w}_{\mathrm{c}}(\%)$ \\
\hline ETFE* $^{*}$ & - & 264 & 41 & 36 \\
\hline \multirow{4}{*}{ ETFE Irradiado } & 20 & 260 & 36 & 32 \\
\hline & 40 & 260 & 47 & 41 \\
\hline & 80 & 259 & 52 & 46 \\
\hline & 100 & 259 & 55 & 48 \\
\hline FEP $^{*}$ & - & 270 & 22 & 27 \\
\hline \multirow{4}{*}{ FEP Irradiado } & 20 & 272 & 28 & 32 \\
\hline & 40 & 272 & 31 & 36 \\
\hline & 80 & 272 & 33 & 38 \\
\hline & 100 & 272 & 31 & 29 \\
\hline $\mathrm{PFA}^{*}$ & - & 311 & 21 & 25 \\
\hline \multirow{4}{*}{ PFA Irradiado } & 20 & 308 & 34 & 41 \\
\hline & 40 & 308 & 30 & 37 \\
\hline & 80 & 309 & 47 & 57 \\
\hline & 100 & 310 & 40 & 48 \\
\hline PTFE* & - & 331 & 38 & 46 \\
\hline \multirow{4}{*}{ PTFE Irradiado } & 20 & 333 & 76 & 91 \\
\hline & 40 & 332 & 80 & 96 \\
\hline & 80 & 333 & 79 & 96 \\
\hline & 100 & 336 & 76 & 91 \\
\hline PVDF* $^{*}$ & - & 170 & 41 & 40 \\
\hline \multirow{4}{*}{ PVDF Irradiado } & 20 & 170 & 36 & 35 \\
\hline & 40 & 166 & 33 & 32 \\
\hline & 80 & 166 & 36 & 35 \\
\hline & 100 & 170 & 39 & 37 \\
\hline
\end{tabular}

* prístino; $\mathrm{T}_{\mathrm{f}}$ : temperatura do pico de fusão; $\Delta \mathrm{H}_{\mathrm{f}}$ : entalpia de fusão; $\mathrm{w}_{\mathrm{c}}$ : grau de cristalinidade. 


\subsection{Enxertia nos filmes em diferentes solventes}

\subsubsection{ETFE}

Na FIG 8 podem ser observados os histogramas com os valores de grau de enxertia em relação ao tempo de reação para os filmes de ETFE em presença dos solventes tolueno, isopropanol ou metanol nas doses de 20, 40, 80 e 100 kGy. O grau de enxertia dos filmes de ETFE enxertados foi calculado pela equação 1.

Pelos gráficos dos filmes de ETFE enxertados observam-se altos rendimentos de enxertia nos três solventes. Em tolueno a enxertia é favorecida quando o filme é irradiado na dose de 100 kGy. Para os solventes isopropanol e metanol a enxertia é favorecida quando os filmes são irradiados a 40 kGy (150,8 \pm $11,3 \%$ e $126 \pm 10 \%$, respectivamente). Analisando as enxertias em meio de tolueno, à exceção dos filmes irradiados a 100 kGy que tiveram valores de DOG muito altos em 14 e 21 dias, pode-se afirmar que os rendimentos de enxertia foram próximos para 7, 14 ou 21 dias. Para os solventes isopropanol e metanol, se isolarmos os dados referentes à dose de $40 \mathrm{kGy}$ que foram muito altos, os filmes também obtiveram valores de enxertia muito próximos nos quatro períodos estudados. O solvente utilizado na reação de enxertia pode promover 0 inchamento do polímero permitindo o acesso do estireno aos sítios ativos criados pela irradiação. O resultado de enxertia depende da difusão do estireno na matriz polimérica decorrente do intumescimento provocado pelo solvente. Após a irradiação as soluções estireno/isopropanol e estireno/metanol apresentaram maior viscosidade à medida que se aumenta a dose de irradiação, ao contrario da solução estireno/tolueno no qual não se observou qualquer mudança na viscosidade. Nos filmes de ETFE, maiores rendimentos de enxertia foram encontrados nas soluções contendo isopropanol ou metanol a 40 kGy. 


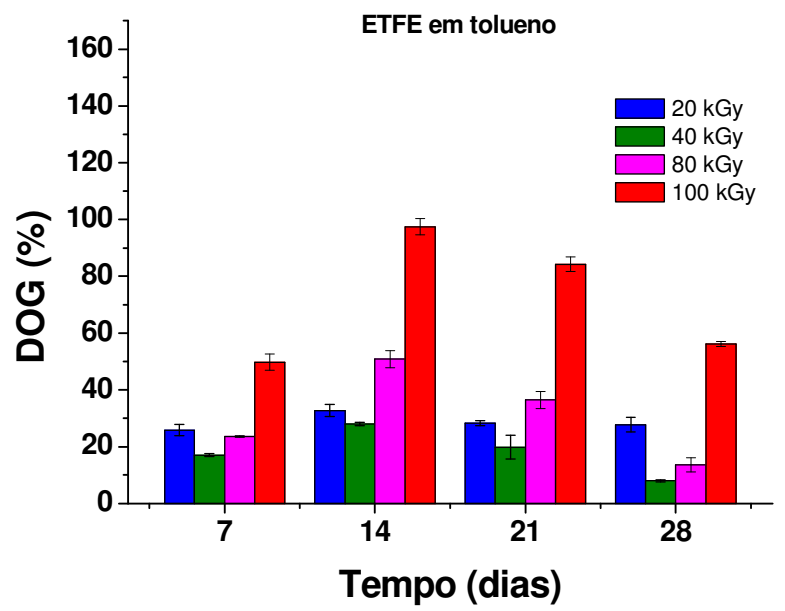

(a)

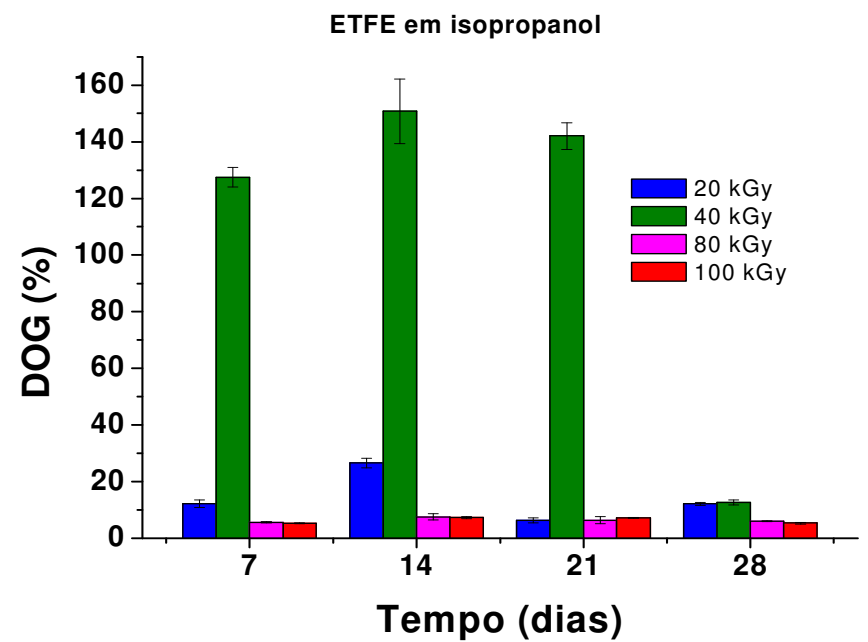

(b)

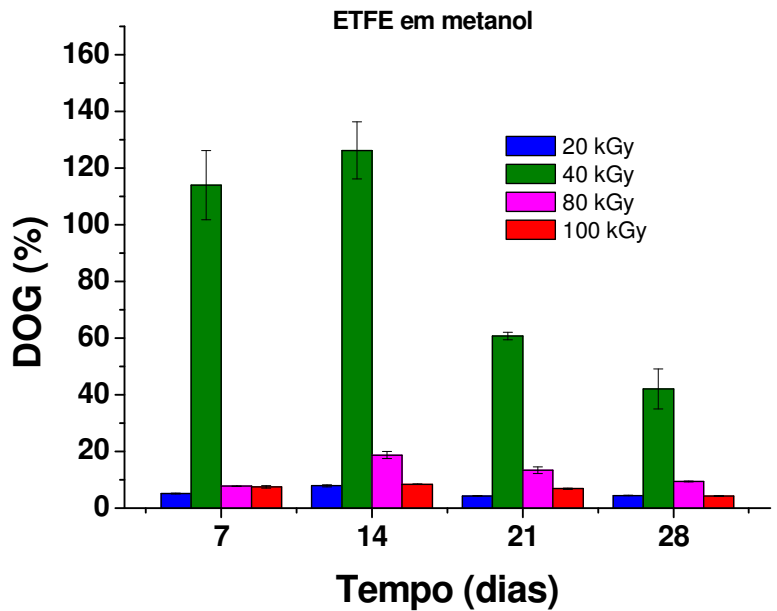

(c)

FIGURA 8: Grau de enxertia (DOG) para os filmes de ETFE (a) em tolueno, (b) em isopropanol e (c) em metanol. 
Os filmes de ETFE enxertados no período de 14 dias foram analisados por TGA e DSC. Os dados das análises térmicas efetuadas nos filmes de ETFE prístino e enxertados nos diferentes solventes são mostrados nas FIGS 9 a 11. Pela análise de TG (FIGS 9, 10 e 11 (a)), observa-se que as degradações, em geral, ocorrem em duas etapas. A primeira etapa de decomposição é atribuída à decomposição do poliestireno enxertado e a segunda pode ser atribuída à matriz polimérica.

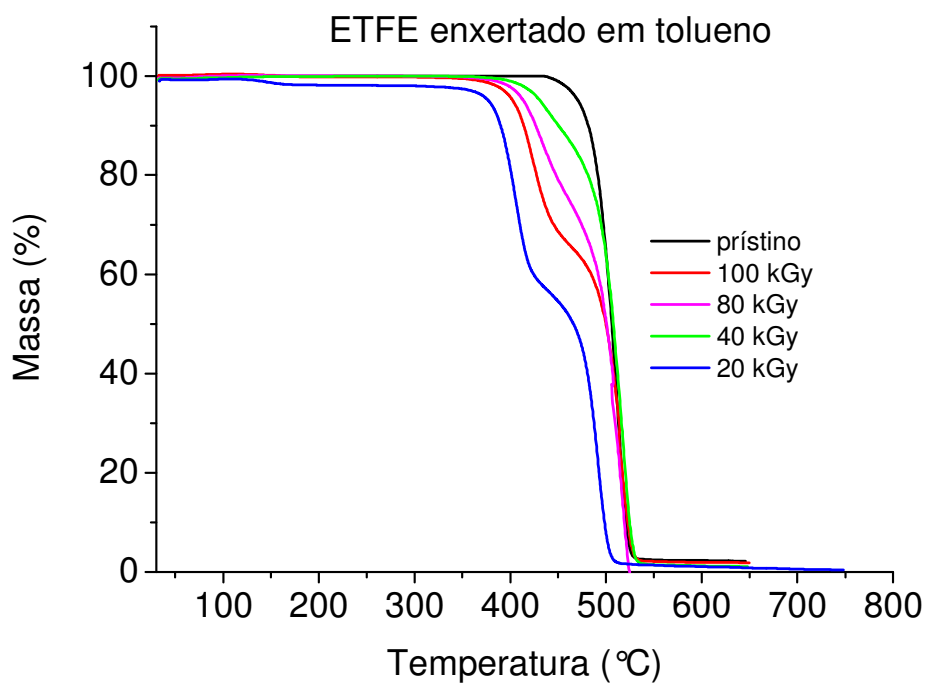

(a)

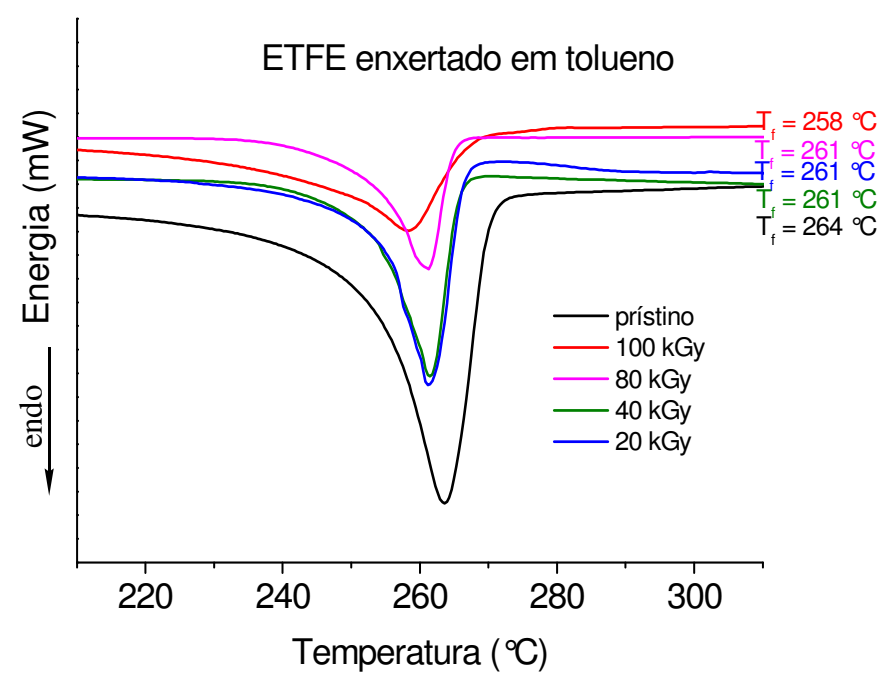

(b)

FIGURA 9: Curvas termogravimétricas (a) e de DSC (b) do ETFE prístino e enxertado no período de 14 dias, nas doses 20, 40, 80 e 100 kGy em tolueno. 


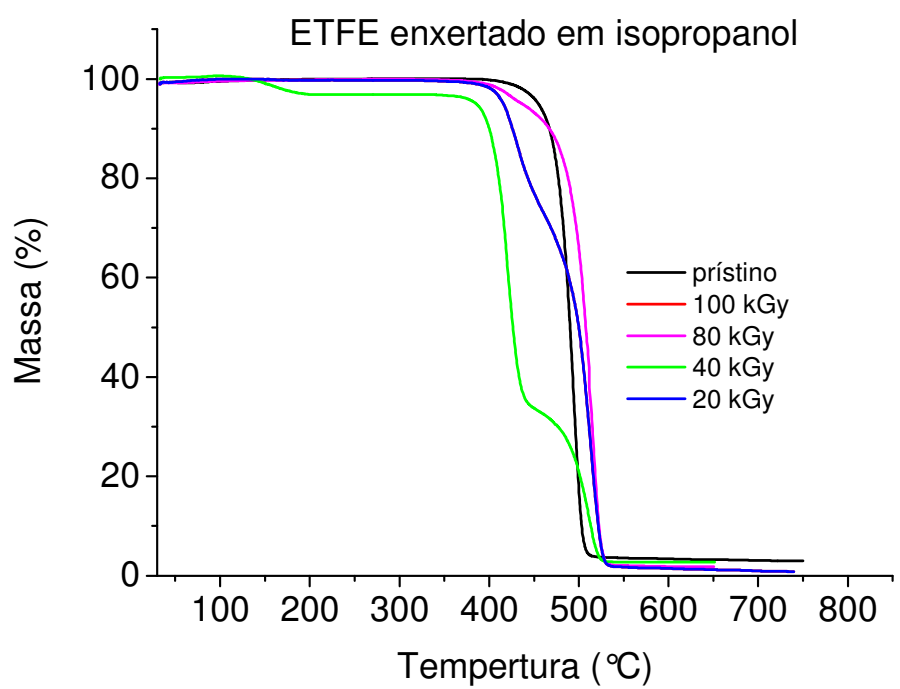

(a)

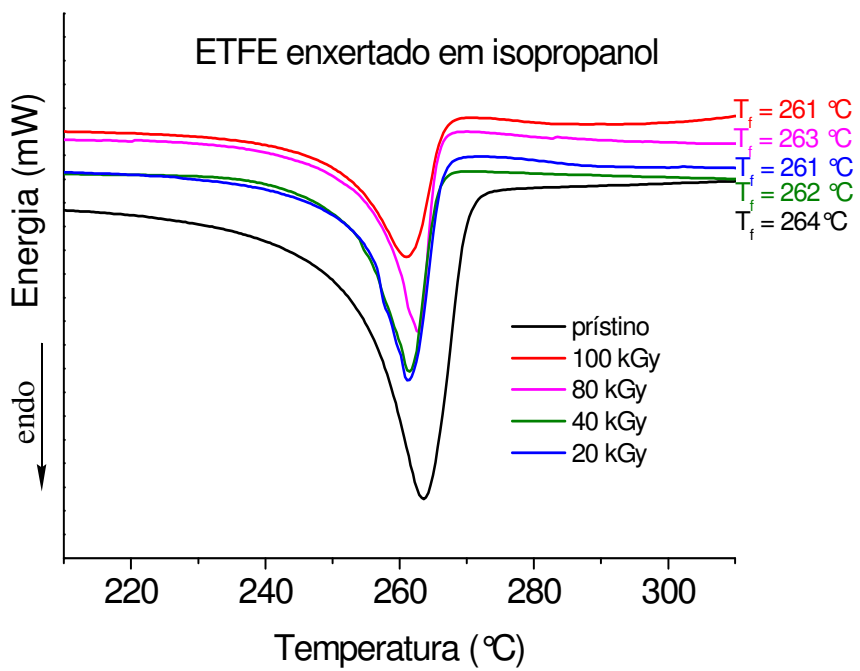

(b)

FIGURA 10: Curvas termogravimétricas (a) e de DSC (b) do ETFE prístino e enxertado no período de 14 dias, nas doses 20, 40, 80 e 100 kGy em isopropanol.

As duas etapas observadas nas curvas TG sugerem que os enxertos de poliestireno são imiscíveis com a matriz polimérica formando fase separada na enxertia dos filmes fluorados [34]. 


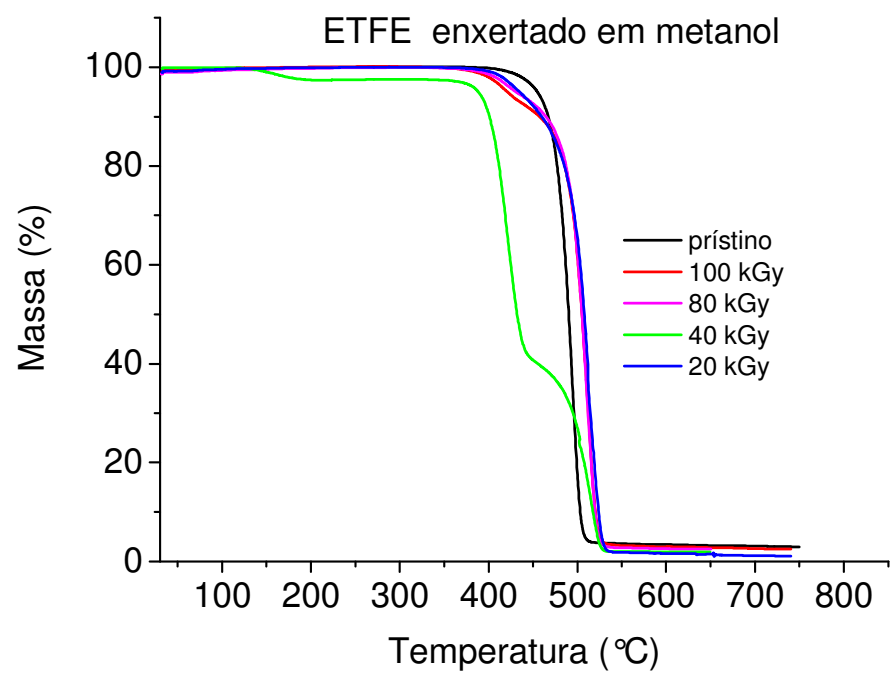

(a)

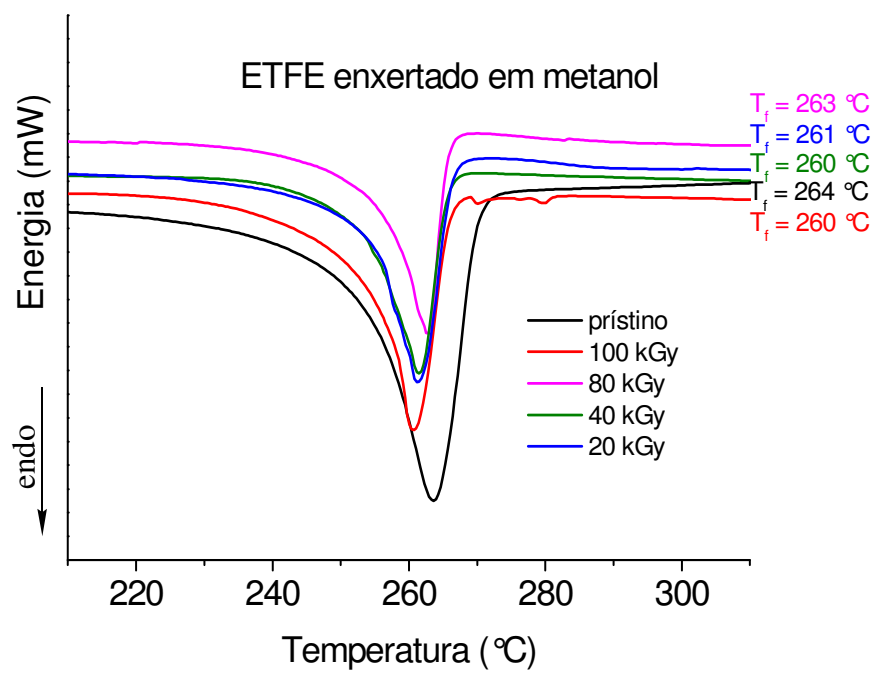

(b)

FIGURA 11: Curvas termogravimétricas (a) e de DSC (b) do ETFE prístino e enxertado no período de 14 dias, nas doses 20, 40, 80 e 100 kGy em metanol.

A $T_{\text {onset }}$ (temperatura de início da decomposição térmica) do ETFE prístino foi $477{ }^{\circ} \mathrm{C}$. Nos filmes enxertados são observadas duas etapas de decomposição, a primeira referente ao poliestireno enxertado que, nos diferentes solventes estudados, se situou entre 393 e $416^{\circ} \mathrm{C}$; e a segunda etapa referente à matriz polimérica ocorreu entre 492 e $504{ }^{\circ} \mathrm{C}$, sugerindo que a matriz está protegida pelos enxertos. 
$\mathrm{Na}$ curva termogravimétrica do filme enxertado em tolueno a $20 \mathrm{kGy}$ (FIG 9a), observam-se três etapas de decomposição térmica. Em torno de $100{ }^{\circ} \mathrm{C}$ observa-se um inicio de perda de massa sugerindo que existem estruturas superficiais de poliestireno de massa molar muito baixa enxertados na matriz. A segunda etapa de decomposição também se inicia a uma temperatura menor $\left(351{ }^{\circ} \mathrm{C}\right.$ ), em comparação as curvas TG das amostras obtidas em outras doses, sugerindo também que os enxertos são superficiais. A próxima etapa de decomposição, atribuída à decomposição da matriz polimérica, ocorre a uma temperatura anterior à decomposição da matriz do filme prístino. Tal observação sugere que os enxertos de poliestireno podem ter aumentado a porosidade da matriz propiciando uma decomposição mais rápida. As demais curvas de TG do ETFE enxertado em 40, 80 e 100 kGy mostram um comportamento de decomposição similar sem apresentar a decomposição inicial atribuída ao poliestireno de baixa massa molar do filme enxertado a $20 \mathrm{kGy}$ bem como a decomposição rápida dos enxertos superficiais. Tal fato pode ser explicado por enxertos mais penetrados no interior da matriz. A Tonset da matriz de ETFE foi ligeiramente maior para essas amostras indicando, portanto que a matriz estava mais "protegida" por enxertos de poliestireno.

As curvas de TG dos filmes enxertados em meio de isopropanol e metanol (FIGs 10 e 11 (a)) a 40 kGy é observada uma perda de massa em torno de $100{ }^{\circ} \mathrm{C}$ indicativo também de poliestireno de massa molar muito baixa enxertado superficialmente na matriz. Acima de $400{ }^{\circ} \mathrm{C}$ a alta perda de massa é atribuída ao poliestireno não muito penetrado na matriz (enxertia superficial). Portanto, o poliestireno enxertado na superfície se degrada termicamente com maior facilidade. É importante destacar que o grau de enxertia na dose de $40 \mathrm{kGy}$ em isopropanol e metanol foram 150,8 $\pm 11,4$ e 126,3 $\pm 10,1 \%$, respectivamente.

As demais curvas de TG do ETFE enxertado em 20, 80 e 100 kGy mostram um comportamento de decomposição similar sem apresentar a decomposição inicial atribuída ao poliestireno de baixa massa molar do filme enxertado a $40 \mathrm{kGy}$ bem como a decomposição rápida dos enxertos superficiais. Tal fato pode ser explicado por enxertos mais penetrados no interior da matriz. A $T_{\text {onset }}$ da matriz de ETFE foi ligeiramente maior para essas amostras indicando, também que a matriz estava mais "protegida" por enxertos de poliestireno. 
Nas curvas de temperatura de fusão $\left(\mathrm{T}_{\mathrm{f}}\right)$ obtidas no primeiro aquecimento (FIGs 9, 10 e 11 (b)) pode-se observar que em todos os filmes enxertados houve pequena variação na $T_{f}$. A literatura relata que a formação de poliestireno enxertado na matriz polimérica não provoca variação na $T_{f}[16,74]$ tendo em vista que as reações de enxertia ocorrem nas regiões amorfas. Provavelmente o grau de cristalinidade foi afetado após a enxertia, porém não é possível utilizar a equação (2) para comprovar esta suposição, pois esta equação é utilizada somente para homopolímero e neste caso as amostras enxertadas são copolímeros e haveria a interferência deste enxerto. Além disso, os enxertos de poliestireno não estão distribuídos de forma homogênea.

\subsubsection{FEP}

Na FIG 12 podem ser observados os histogramas com os valores de grau de enxertia (calculados pela equação 1) em relação ao tempo de reação para os filmes de FEP em presença dos solventes tolueno, isopropanol ou metanol nas doses de 20, 40, 80 e 100 kGy. 


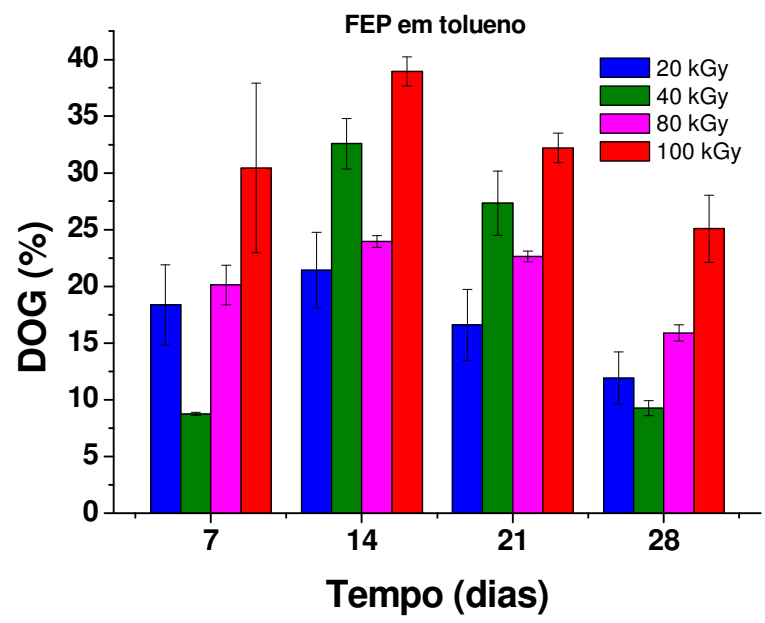

(a)

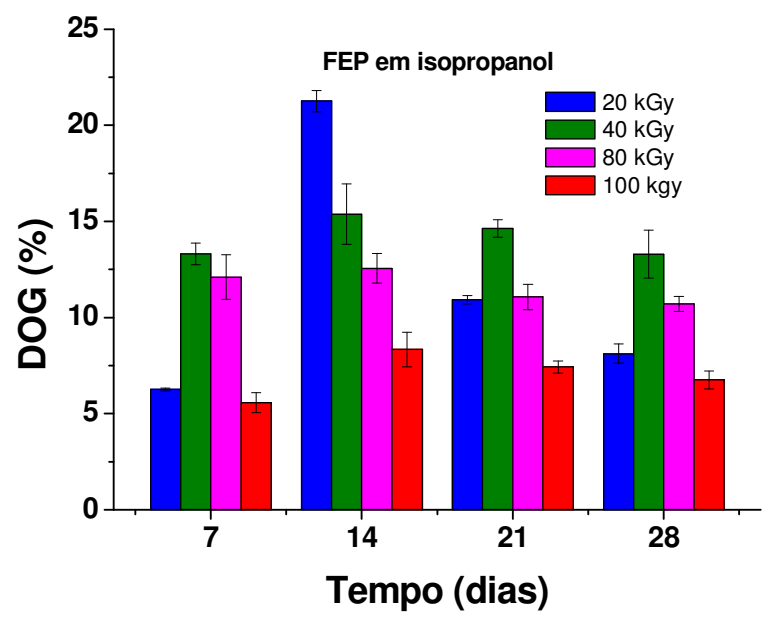

(b)

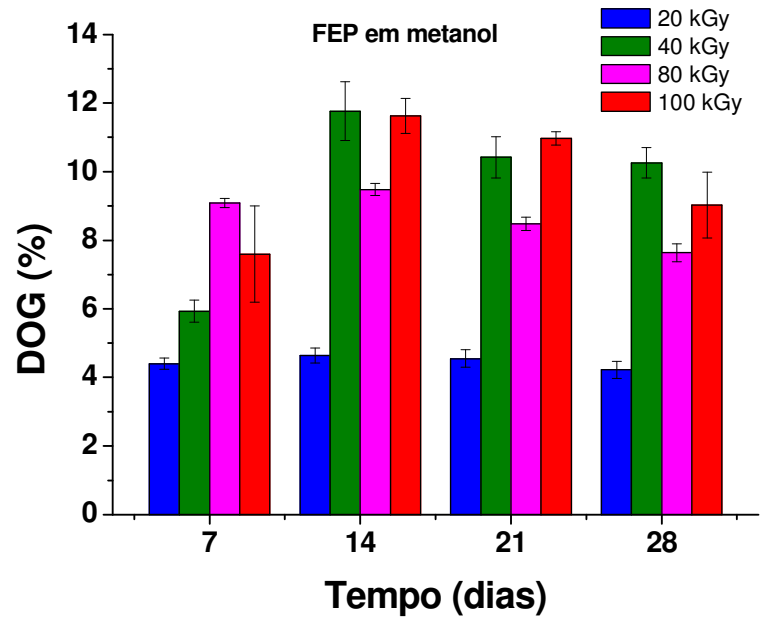

(c)

FIGURA 12: Grau de enxertia (DOG) para os filmes de FEP (a) em tolueno, (b) em isopropanol e (c) em metanol. 
No período de 14 dias, o FEP revelou maior rendimento de enxertia em tolueno, quando comparado aos outros solventes estudados. À exceção da dose de 100 kGy, os valores de DOG para este solvente são bem próximos nos períodos de 7, 14 (exceto também a 40 kGy) e 21 dias. Em isopropanol no período de 14 dias, os maiores rendimentos de enxertia são encontrados a 20 kGy. Para o metanol os valores de enxertia a 14 dias são bem próximos nas doses de 40, 80 e 100 kGy. De maneira geral, as enxertias em isopropanol e metanol apresentaram rendimentos baixos nos períodos de 7 a 28 dias. Para os filmes de FEP, a maior enxertia foi favorecida nas soluções contendo tolueno, pois as maiores viscosidades encontradas nas soluções contendo isopropanol ou metanol desfavorecem a difusão do monômero aos sítios ativos.

Os filmes de FEP enxertados no período de 14 dias foram analisados por TG. Para o FEP enxertado (FIGs 13, 14 e 15 (a)) as degradações ocorrem em três etapas: ${ }^{1} T_{\text {onset: }}$ temperatura inicial de decomposição do estireno enxertado; ${ }^{2} T_{\text {onset: }}$ temperatura inicial de decomposição do hexafluoropropileno que possui um carbono terciário que torna a ligação mais fraca $\mathrm{e}^{3} \mathrm{~T}_{\text {onset }}$ : temperatura inicial de decomposição do politetrafluoroetileno.

$\mathrm{A}^{2} \mathrm{~T}_{\text {onset }}$ do FEP prístino foi a $474{ }^{\circ} \mathrm{C}$ referente à decomposição do hexafluoropropileno e $555{ }^{\circ} \mathrm{C}$ referente ao politetrafluoroetileno. Nos filmes enxertados a ${ }^{1} \mathrm{~T}_{\text {onset }}$ para os diferentes solventes estudados foi entre $391 \mathrm{e}$ $408{ }^{\circ} \mathrm{C}$. A segunda etapa de decomposição $\left({ }^{2} \mathrm{~T}_{\text {onset }}\right)$ ocorreu entre 478 e $540{ }^{\circ} \mathrm{C}$ e $\mathrm{a}^{3} \mathrm{~T}_{\text {onset }}$ aconteceu entre 541 e $563{ }^{\circ} \mathrm{C}$. 


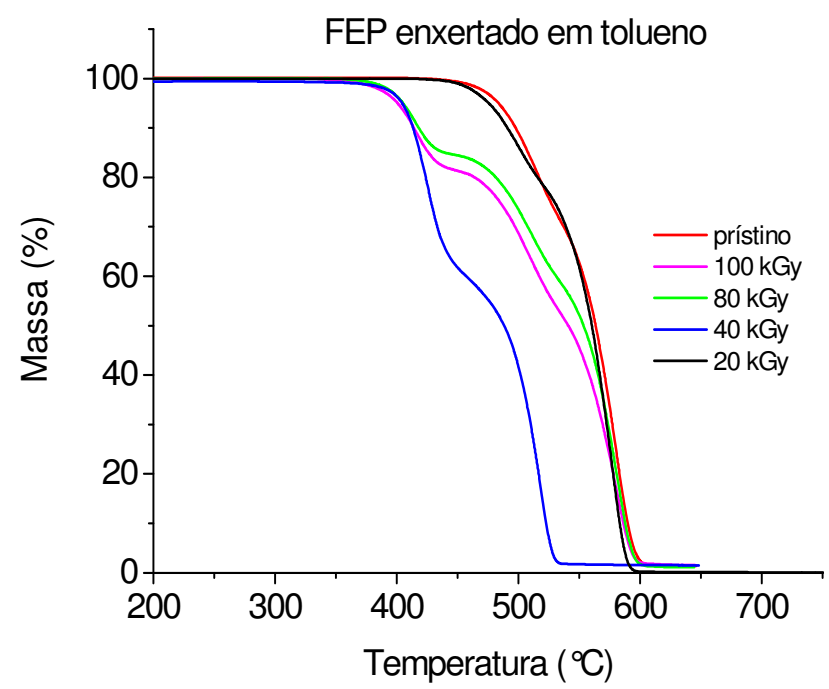

(a)

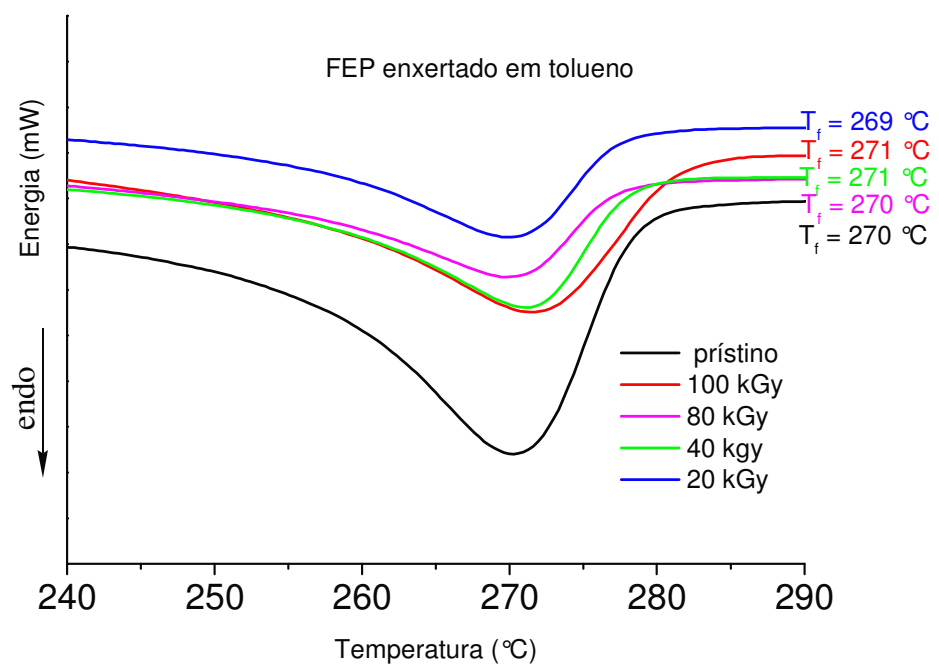

(b)

FIGURA 13: Curvas termogravimétricas (a) e de DSC (b) do FEP prístino e enxertado no período de 14 dias, nas doses 20, 40, 80 e 100 kGy em tolueno.

Nas curvas termogravimétricas para os três solventes estudados (FIGs 13,14 e 15 (a)) observa-se que os filmes enxertados apresentaram menor estabilidade térmica comparativamente ao filme prístino, revelando um menor efeito de "proteção" da matriz atribuído ao poliestireno comentado no item 5.2.1. Somente o filme enxertado em tolueno a 100 kGy (FIG 13 (a)) mostrou discreto aumento na estabilidade provavelmente atribuído ao fato de que a esta dose o valor de DOG ser maior $(39,0 \pm 1,3 \%)$. Em tolueno a $20 \mathrm{kGy}$, observam-se 
apenas duas etapas de decomposição: a primeira em $408{ }^{\circ} \mathrm{C}$ referente ao poliestireno enxertado e a segunda a $541{ }^{\circ} \mathrm{C}$ referente à decomposição da matriz polimérica. As duas etapas de decomposição que ocorrem em temperaturas menores que as esperadas podem ser atribuídas ao fato de que os enxertos de poliestireno aumentaram a porosidade da matriz propiciando uma decomposição mais rápida. Já nas doses de 40 e 80 kGy as três etapas de decomposição foram observadas.

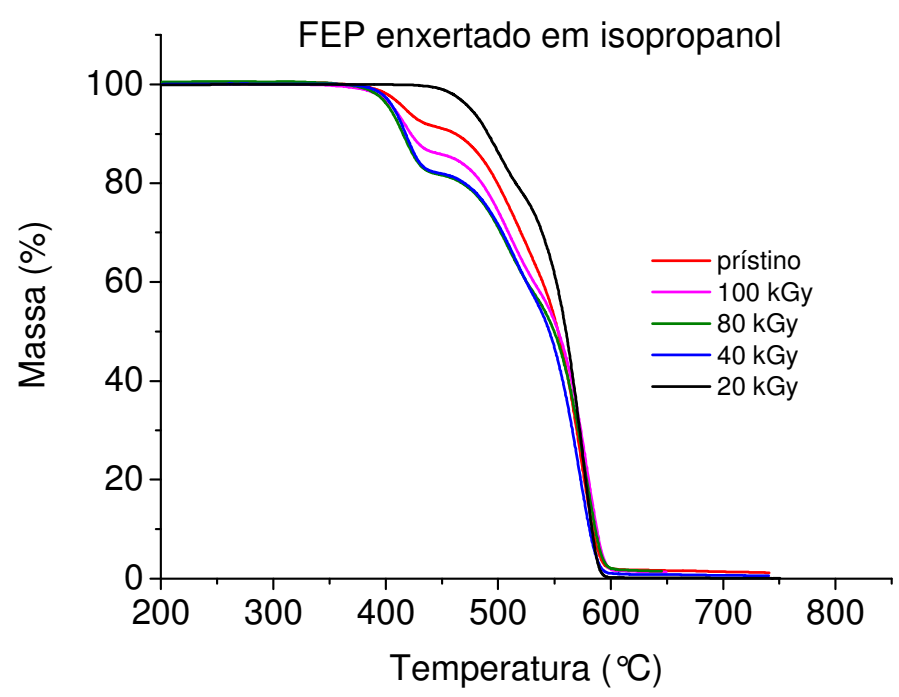

(a)

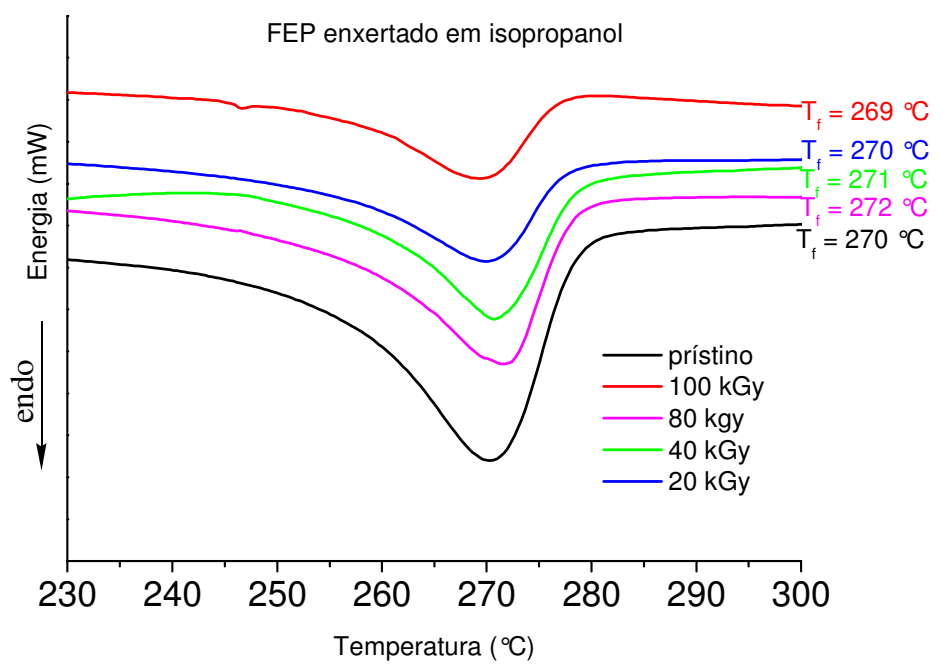

(b)

FIGURA 14: Curvas termogravimétricas (a) e de DSC (b) do FEP prístino e enxertado no período de 14 dias, nas doses 20, 40, 80 e 100 kGy em isopropanol. 
Nos filmes enxertados em isopropanol (FIG 14 (a)) nas doses de 20 e 40 kGy, a degradação foi semelhante, assim como os valores de DOG para as membranas enxertadas em 20 kGy $21,4 \pm 0,5 \%$ e 40 kGy 15,4 \pm 1,6 \%. Provavelmente, a porcentagem de poliestireno enxertado interna e externamente à matriz foram semelhantes para as duas doses.

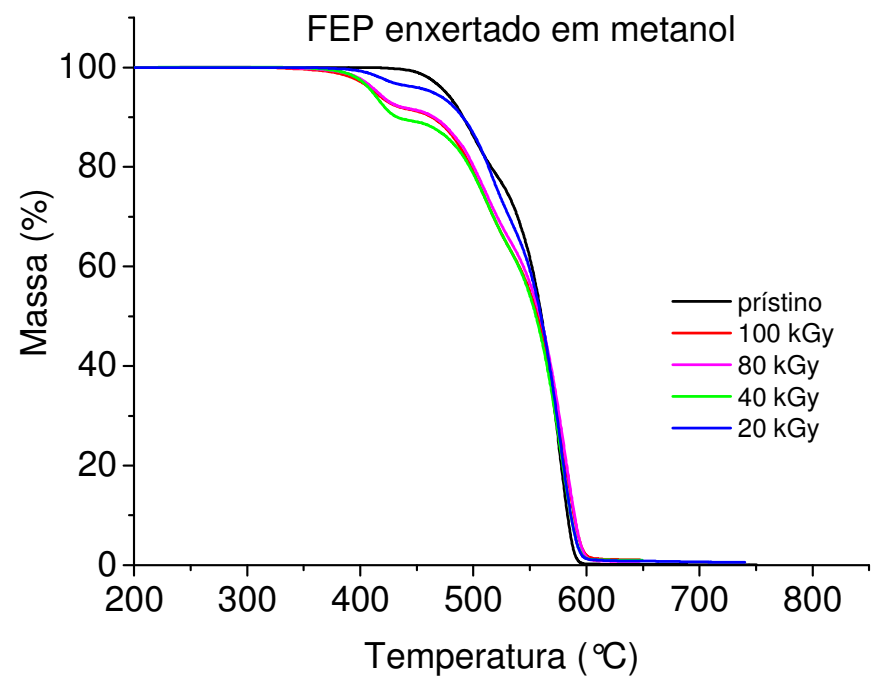

(a)

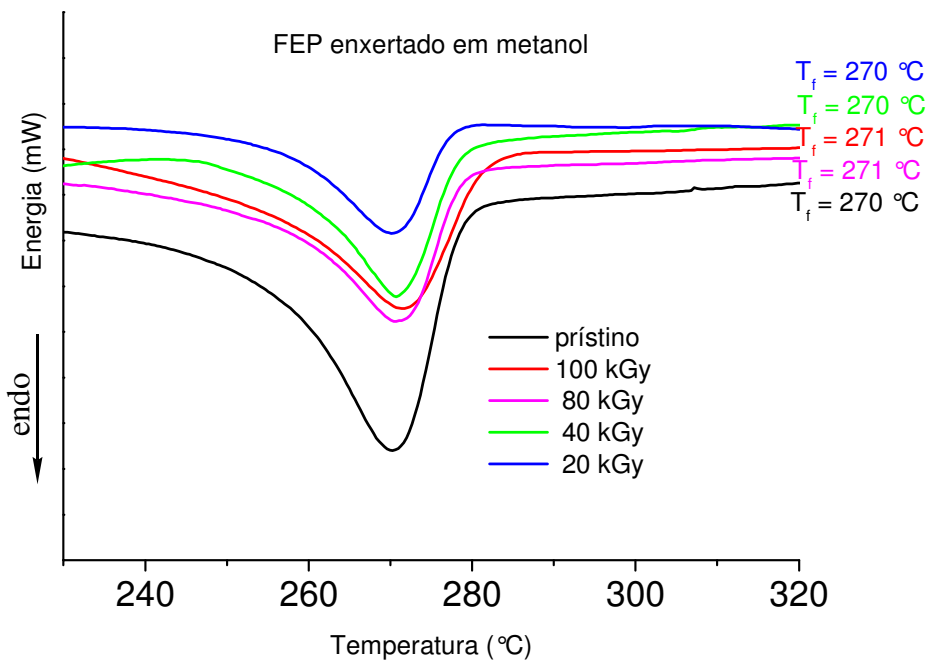

(b)

FIGURA 15: Curvas termogravimétricas (a) e de DSC (b) do FEP prístino e enxertado no período de 14 dias, nas doses 20, 40, 80 e 100 kGy em metanol. 
Nas enxertias em metanol (FIG 15 (a)) as doses de 40, 80 e 100 kGy apresentaram DOG de 11,8 \pm 0,8 \%, 9,5 \pm 0,3 \% e 11,6 \pm 0,5 \% e perda de massa de poliestireno, hexafluoropropileno e matriz semelhantes.

Nas curvas de temperatura de fusão $\left(\mathrm{T}_{\mathrm{f}}\right)$ obtidas no primeiro aquecimento (FIGs 13, 14 e 15 (b)) pode-se observar que em todos os filmes enxertados houve pequena variação na $T_{f}$ semelhantemente ao que ocorre nos filmes de ETFE enxertados.

\subsubsection{PFA}

Na FIG 16 podem ser observados os histogramas com os valores de grau de enxertia (calculado pela equação 1) em relação ao tempo de reação para os filmes de PFA em presença dos solventes tolueno, isopropanol ou metanol nas doses de 20, 40, 80 e 100 kGy.

Nas enxertias em tolueno, observa-se que na dose de 20 kGy os valores de DOG são próximos nos quatro períodos estudados, sendo o maior valor em 14 dias (26,5 $\pm 1,4 \%$ ). Para a dose de $40 \mathrm{kGy}$, em 14 dias o DOG foi de $37,5 \pm 2,4 \%$ e nos períodos de 7, 21 e 28 dias os valores foram próximos. Para a dose de $80 \mathrm{kGy}$ as enxertias foram próximas nos períodos de 14 e 21 dias e idênticas em 7 e 28 dias com o maior valor em 14 dias (41,3 0 0,8\%). A 100 kGy o maior valor foi em 14 dias $(74,4 \pm 3,6 \%$ ) e enxertias entre 50 e $60 \%$ nos períodos de 7, 21 e 28 dias. Ainda em tolueno, os maiores valores de enxertia são encontrados na dose de 100 kGy $(74,4 \pm 3,6 \%)$. 


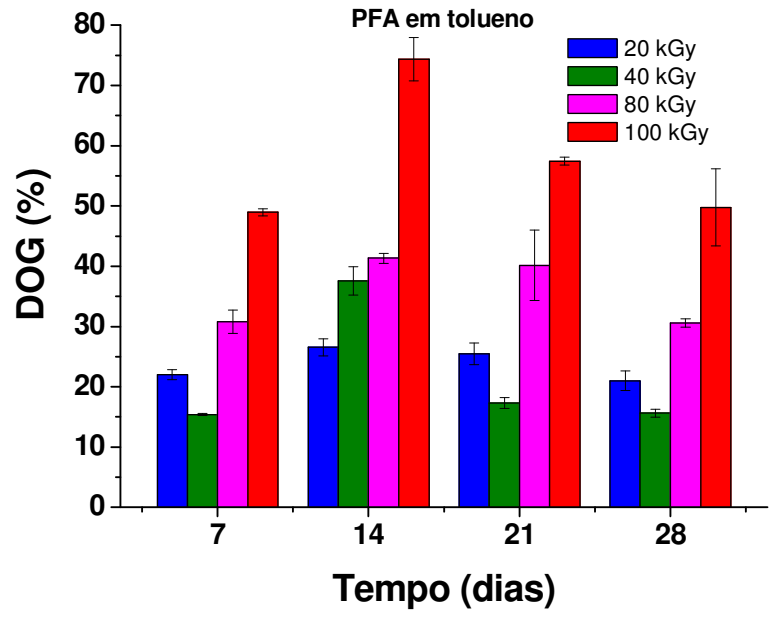

(a)

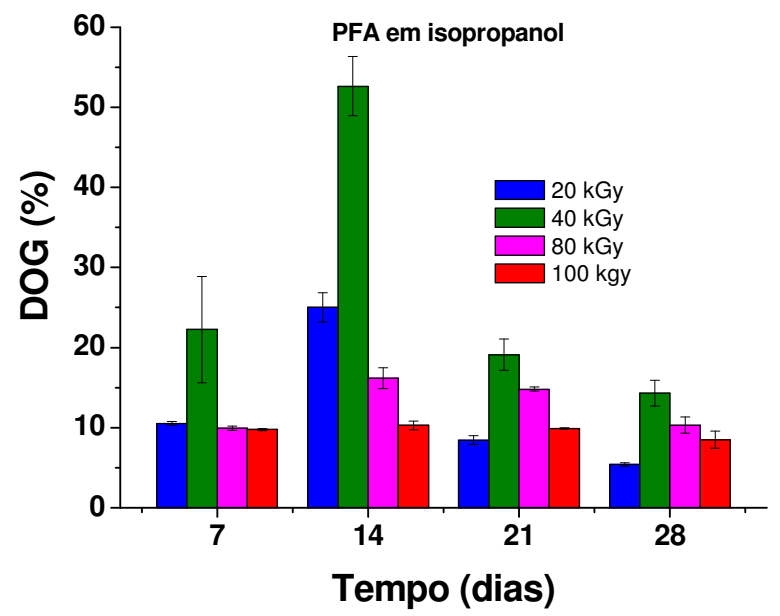

(b)

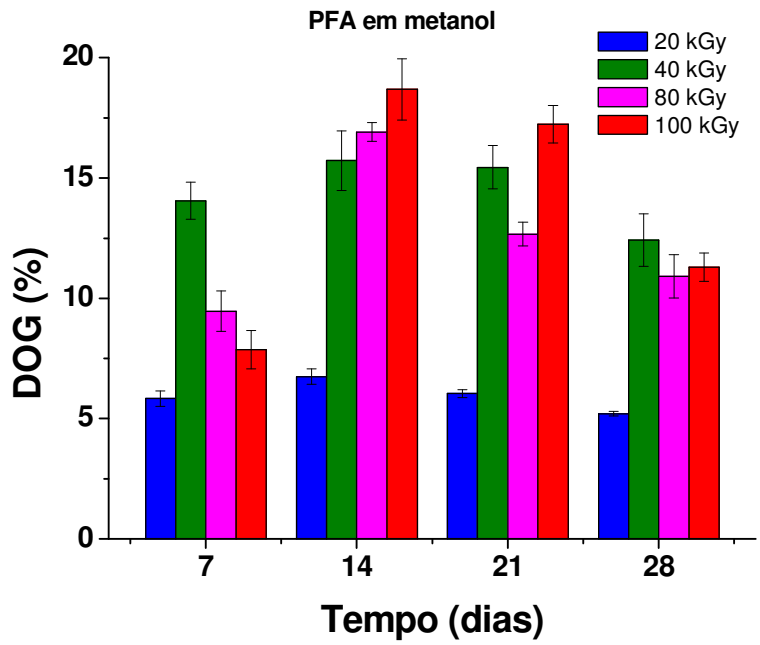

(c)

FIGURA 16: Grau de enxertia (DOG) para os filmes de PFA (a) em tolueno, (b) em isopropanol e (c) em metanol. 
Nas enxertias em isopropanol o maior valor de DOG foi observado a 14 dias para os filmes irradiados a 40 kGy.

Nas enxertias em metanol os valores de DOG após 14 dias são bem próximos nas doses de 40 kGy (15,7 $\pm 1,2 \%), 80$ kGy $(17,0 \pm 0,4 \%)$ e 100 kGy $(18,7 \pm 1,3 \%)$. As enxertias em $20 \mathrm{kGy}$ foram muito baixas menores que $7 \%$. Portanto nos filmes de PFA, a maior enxertia foi favorecida nas soluções contendo tolueno. Por outro lado, as maiores viscosidades encontradas nas soluções contendo isopropanol ou metanol desfavoreceram a difusão do monômero aos sítios ativos.

A $\mathrm{T}_{\text {onset }}$ do PFA (FIG 17) prístino foi a $524{ }^{\circ} \mathrm{C}$. As curvas termogravimétricas dos filmes de PFA enxertados mostram duas etapas de decomposição, sendo a primeira etapa referente ao poliestireno enxertado, que nos diferentes solventes estudados se situou entre 394 e $408{ }^{\circ} \mathrm{C}$. E a segunda etapa que aconteceu entre 521 e $527^{\circ} \mathrm{C}$.

No solvente tolueno, o maior valor de enxertia foi obtido na dose de 100 kGy (74,4 $\pm 3,6 \%$ ). Na FIG 17 (a) é observado um início de decomposição do poliestireno enxertado a temperatura inferior à das demais doses, sugerindo a presença de enxertos superficiais que volatilizam mais facilmente quando submetido ao aumento de temperatura. Tal observação também pode servir para a curva TG do PFA enxertado em isopropanol a 40 kGy (FIG 17 (b)).

Nas curvas termogravimétricas relativas aos solventes tolueno e isopropanol (FIGs 17a e b) observam-se que os filmes enxertados apresentaram menor estabilidade térmica que o filme prístino. Sugerindo que a matriz polimérica está menos "protegida" pelos enxertos de poliestireno. Somente em metanol (FIG 17c) é observado um pequeno aumento na estabilidade térmica com relação ao prístino. 


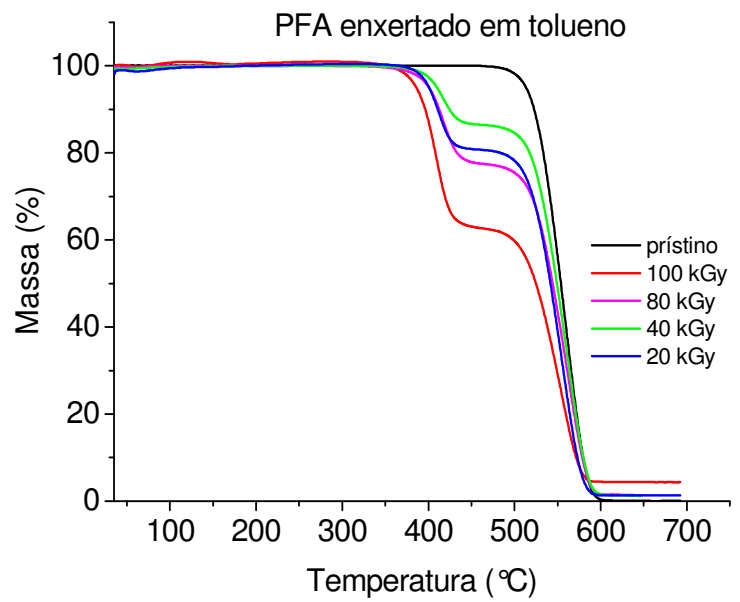

(a)

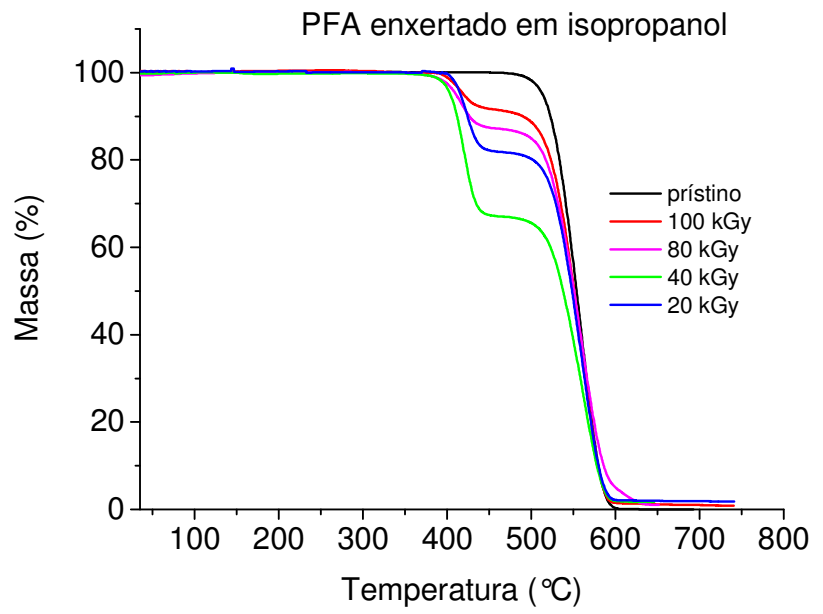

(b)

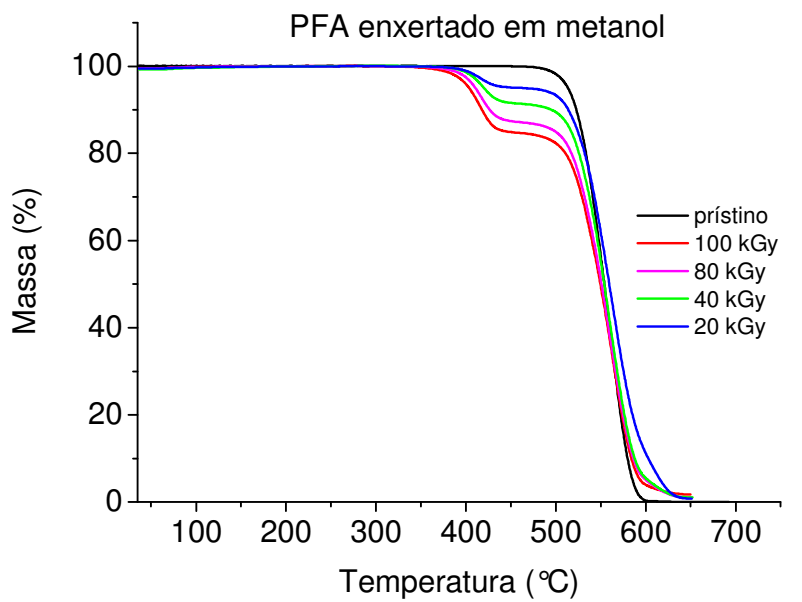

(c)

FIGURA 17: Curvas termogravimétricas do PFA prístino e enxertado no período de 14 dias, nas doses 20, 40, 80 e 100 kGy (a) em tolueno, (b) em isopropanol e (c) em metanol. 
As temperaturas de fusão $\left(T_{f}\right)$ obtidas no primeiro aquecimento (TAB 6) de todos os filmes enxertados mostraram-se próximas entre si e também próximas à $T_{f}$ do filme prístino. Tal observação está concordante com a literatura $[16,74]$ que afirma que a formação de poliestireno enxertado na matriz polimérica não provoca variação na $T_{f}$, pois tais reações de enxertia ocorrem nas regiões amorfas.

TABELA 6: Valores obtidos na análise de DSC para os filmes de PFA prístino e enxertados nas doses de 20, 40, 80 e 100 kGy.

\begin{tabular}{c|c|c|c}
\hline Amostra/Solvente & Dose (kGy) & $\mathrm{DOG}(\%)$ & $\mathrm{T}_{\mathrm{f}}\left({ }^{\circ} \mathrm{C}\right)$ \\
\hline PFA $^{*}$ & - & - & 313 \\
\hline \multirow{4}{*}{ PFA/tolueno } & 20 & $26,5 \pm 1,4$ & 309 \\
\cline { 2 - 4 } & 40 & $37,5 \pm 2,4$ & 310 \\
\cline { 2 - 4 } & 80 & $41,3 \pm 0,8$ & 310 \\
\cline { 2 - 4 } & 100 & $74,4 \pm 3,6$ & 308 \\
\hline \multirow{4}{*}{ PFA/isopropanol } & 20 & $25,0 \pm 1,8$ & 309 \\
\cline { 2 - 4 } & 40 & $52,6 \pm 3,7$ & 309 \\
\cline { 2 - 4 } & 80 & $16,2 \pm 1,3$ & 311 \\
\hline \multirow{4}{*}{ PFA/metanol } & 100 & $10,3 \pm 0,5$ & 310 \\
\cline { 2 - 4 } & 20 & $6,74 \pm 0,3$ & 309 \\
\cline { 2 - 4 } & 40 & $15,7 \pm 1,2$ & 310 \\
\cline { 2 - 4 } & 100 & $17,0 \pm 0,4$ & 310 \\
\hline
\end{tabular}

*: prístino; DOG: grau de enxertia; $\mathrm{T}_{\mathrm{f}}$ : temperatura do pico de fusão.

\subsubsection{PTFE}

Na FIG 18 podem ser observados os histogramas com os valores de grau de enxertia, calculados pela equação 1, em relação ao tempo de reação para os filmes de PTFE em presença dos solventes tolueno, isopropanol ou metanol nas doses de 20, 40, 80 e 100 kGy. 


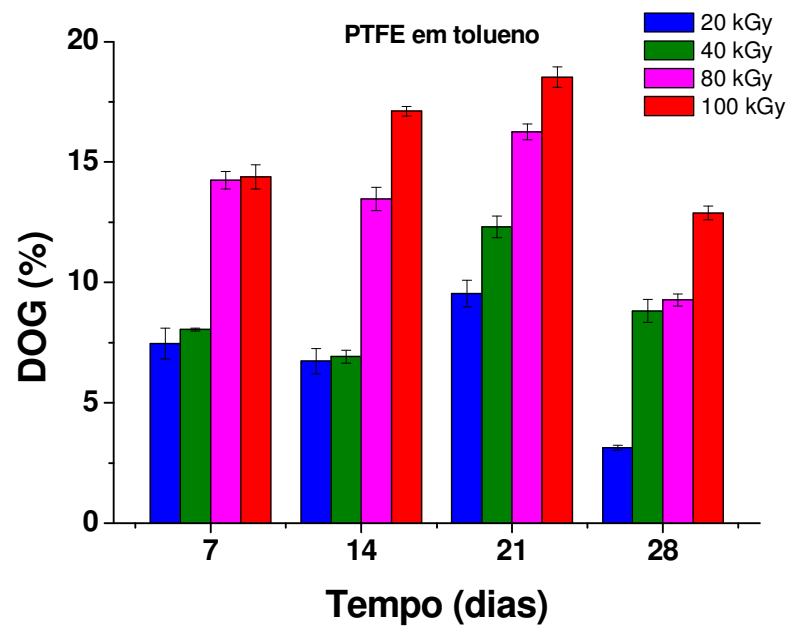

(a)

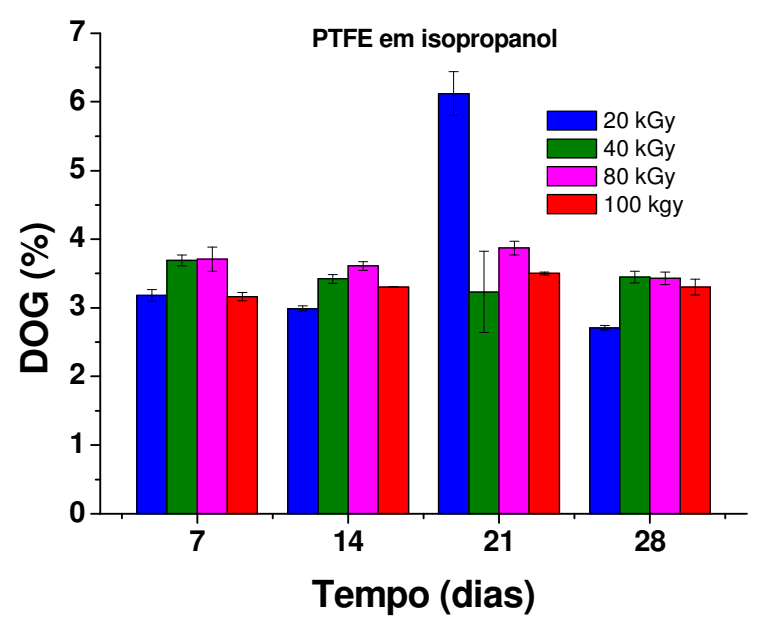

(b)

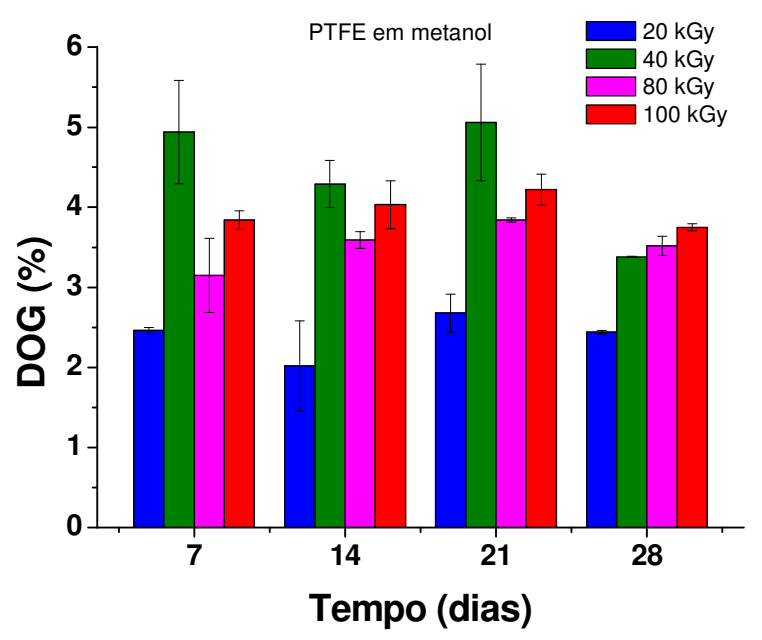

(c)

FIGURA 18: Grau de enxertia (DOG) para os filmes de PTFE (a) em tolueno, (b) em isopropanol e (c) em metanol. 
Para os filmes de PTFE, os maiores valores de enxertia são encontrados após 21 dias de reação no tolueno. As doses de 80 e 100 kGy determinaram o maior grau de enxertia. Os solventes isopropanol e metanol não favorecem a enxertia no PTFE. Como a cristalinidade dos filmes de PTFE irradiados aumenta após a exposição à radiação (item 5.1 desta tese) e a enxertia ocorre na fase amorfa do polímero [42] já era esperado que o rendimento de enxertia nestes filmes fosse baixo. O melhor rendimento de enxertia verificado em soluções contendo tolueno pode ser atribuído ao intumescimento da matriz polimérica pelo solvente aumentando a difusão do estireno na matriz. Os solventes isopropanol e metanol não intumescem a matriz de PTFE desfavorecendo, portanto a enxertia.

Tal observação é confirmada pelas curvas termogravimétricas (FIG 19 b e c) que mostram uma pequena perda de massa referente ao poliestireno enxertado além dos filmes enxertados possuírem maior estabilidade térmica quando comparados ao filme prístino. A FIG 19a referente à análise térmica dos filmes enxertados em tolueno confirmam que a maior enxertia ocorreu a $100 \mathrm{kGy}$ seguido de 80 kGy, 40 kGy e 20 kGy. A T onset do PTFE (FIG 19) prístino foi a 555 ${ }^{\circ} \mathrm{C}$. As curvas termogravimétricas destes filmes enxertados mostram duas etapas de decomposição, a primeira referente ao poliestireno enxertado, que nos diferentes solventes estudados foi entre 390 e $407{ }^{\circ} \mathrm{C}$; e a segunda etapa de decomposição aconteceu entre 559 e $573{ }^{\circ} \mathrm{C}$. 


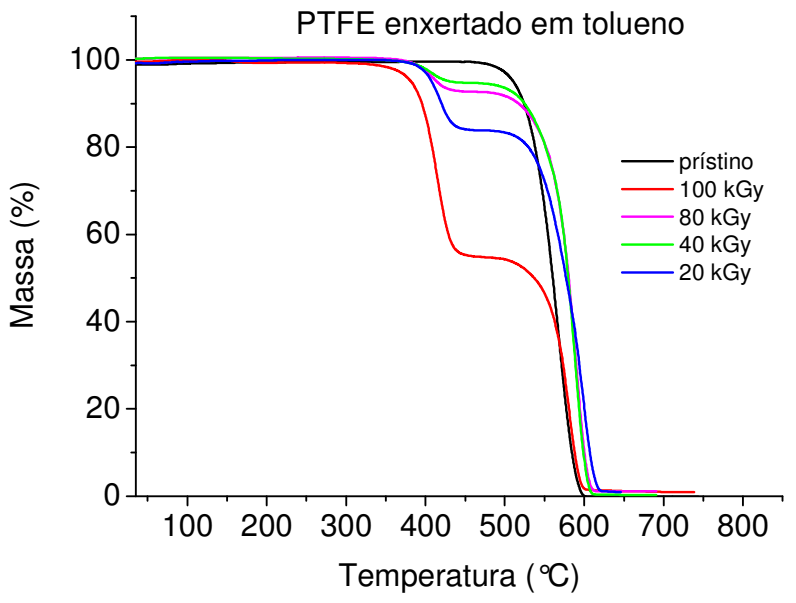

(a)

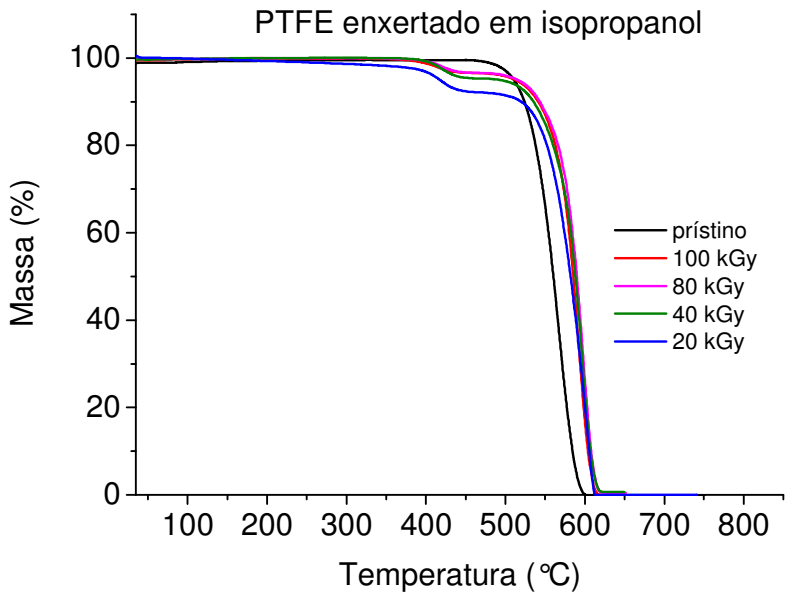

(b)

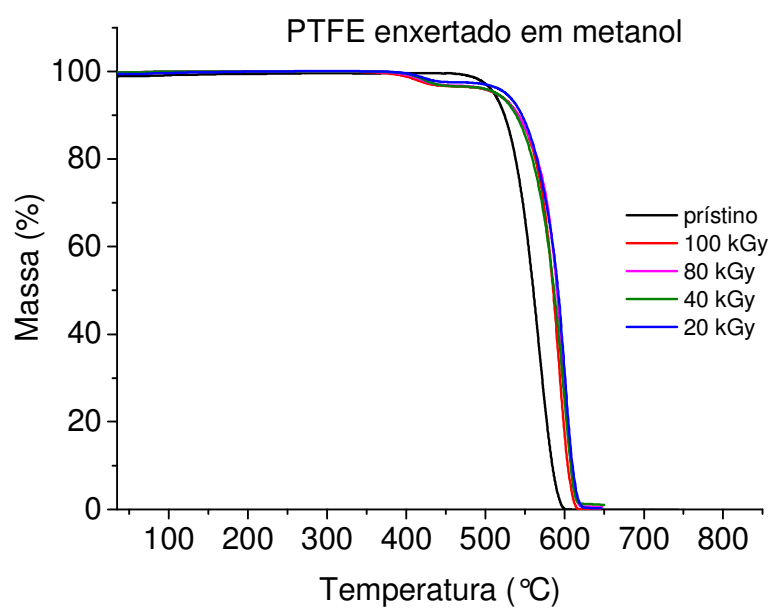

(c)

FIGURA 19: Curvas termogravimétricas do PTFE prístino e enxertado no período de 21 dias, nas doses 20, 40, 80 e 100 kGy (a) em tolueno, (b) em isopropanol e (c) em metanol. 
As temperaturas de fusão $\left(T_{f}\right)$ obtidas no primeiro aquecimento (TAB 7) de todos os filmes enxertados mostraram-se próximas entre si e também próximas à $T_{f}$ do filme prístino.

TABELA 7: Valores obtidos na análise de DSC para os filmes de PTFE prístino e enxertados nas doses de 20, 40, 80 e 100 kGy.

\begin{tabular}{c|c|c|c}
\hline Amostra/Solvente & Dose (kGy) & DOG (\%) & $\mathrm{T}_{\mathrm{f}}\left({ }^{\circ} \mathrm{C}\right)$ \\
\hline PTFE* $^{*}$ & - & - & 331 \\
\hline \multirow{4}{*}{ PTFE/tolueno } & 20 & $9,54 \pm 0,55$ & 332 \\
\cline { 2 - 4 } & 40 & $12,3 \pm 0,4$ & 332 \\
\cline { 2 - 4 } & 100 & $16,2 \pm 0,3$ & 334 \\
\hline \multirow{4}{*}{ PTFE/isopropanol } & 20 & $6,12 \pm 0,3$ & 333 \\
\cline { 2 - 4 } & 40 & $3,23 \pm 0,59$ & 334 \\
\cline { 2 - 4 } & 100 & $3,87 \pm 0,10$ & 333 \\
\hline \multirow{5}{*}{ PTFE/metanol } & 20 & $2,68 \pm 0,23$ & 332 \\
\cline { 2 - 4 } & 40 & $5,05 \pm 0,73$ & 334 \\
\cline { 2 - 4 } & 80 & $3,84 \pm 0,02$ & 333 \\
\cline { 2 - 4 } & 100 & $4,22 \pm 0,19$ & 333 \\
\hline
\end{tabular}

*: prístino; DOG: grau de enxertia; $\mathrm{T}_{\mathrm{f}}$ : temperatura do pico de fusão.

\subsubsection{PVDF}

$\mathrm{Na}$ FIG 20 podem ser observados os histogramas com os valores de grau de enxertia (calculados pela equação 1) em relação ao tempo de reação para os filmes de PVDF em presença dos solventes tolueno, isopropanol ou metanol nas doses de 20, 40, 80 e 100 kGy.

Para os filmes de PVDF, os maiores valores de enxertia são encontrados após 21 dias de reação. Em tolueno, os maiores valores de enxertia são encontrados a 20 e 40 kGy. No período de 14 dias as doses de 20 e 40 kGy também favoreceram maior enxertia. Nas doses de 80 e 100 kGy a enxertia é muito baixa. O decréscimo no grau de enxertia possivelmente pode ser explicado por cisões ocorrendo em enxertos de alta massa molar que se tornam frágeis no 
sistema reacional. A cisão do enxerto de poliestireno deve ocorrer simultaneamente à reação de terminação do material sob tratamento térmico. Em isopropanol os maiores valores de enxertia são encontrados a $40 \mathrm{kGy}$ nos quatro períodos estudados, sendo em 21 dias o maior valor. Nas doses de 80 e 100 kGy a enxertia é baixa. Para o metanol os maiores valores de enxertia são também encontrados a 40 kGy nos quatro períodos estudados, sendo em 21 dias o maior valor. Nas doses de 80 e 100 kGy a enxertia é baixa. Portanto a enxertia nos solventes isopropanol e metanol é favorecida na dose de 40 kGy. Já no solvente tolueno, as melhores doses são 20 e 40 kGy.

Pela análise de TG, a $\mathrm{T}_{\text {onset }}$ do PVDF prístino foi a $437{ }^{\circ} \mathrm{C}$. Nos filmes enxertados verificam-se duas etapas de decomposição, a primeira referente ao poliestireno enxertado que nos diferentes solventes estudados foi entre 393 e 400 ${ }^{\circ} \mathrm{C}$ e a segunda etapa referente à matriz polimérica ocorreu entre 425 e $461{ }^{\circ} \mathrm{C}$. As análises de DSC mostraram também pequena variação na $T_{f}$. Para o filme prístino a $T_{f}$ foi de $170{ }^{\circ} \mathrm{C}$ e para os filmes enxertados nos vários solventes a temperatura do pico de fusão variou entre 164 e $169{ }^{\circ} \mathrm{C}$. Os filmes de PVDF enxertados mostraram-se bastante degradados durante o processo de enxertia e não resistiram à sulfonação. 


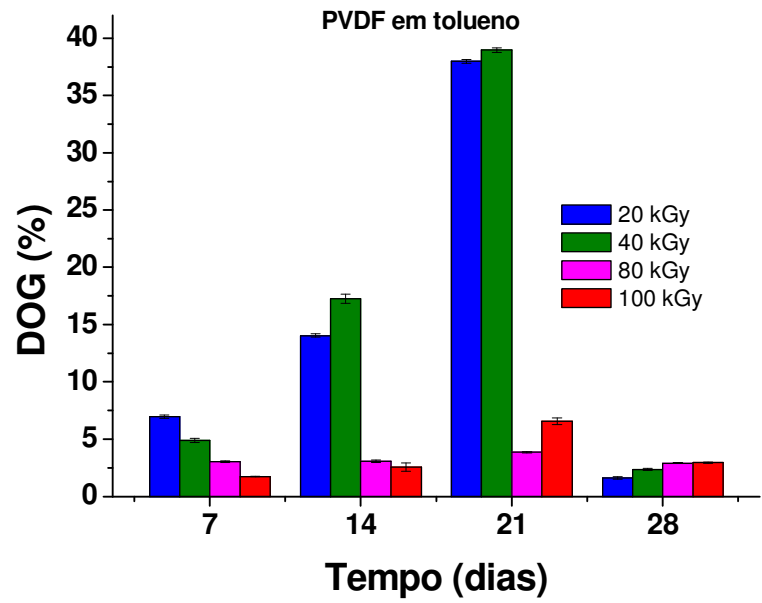

(a)

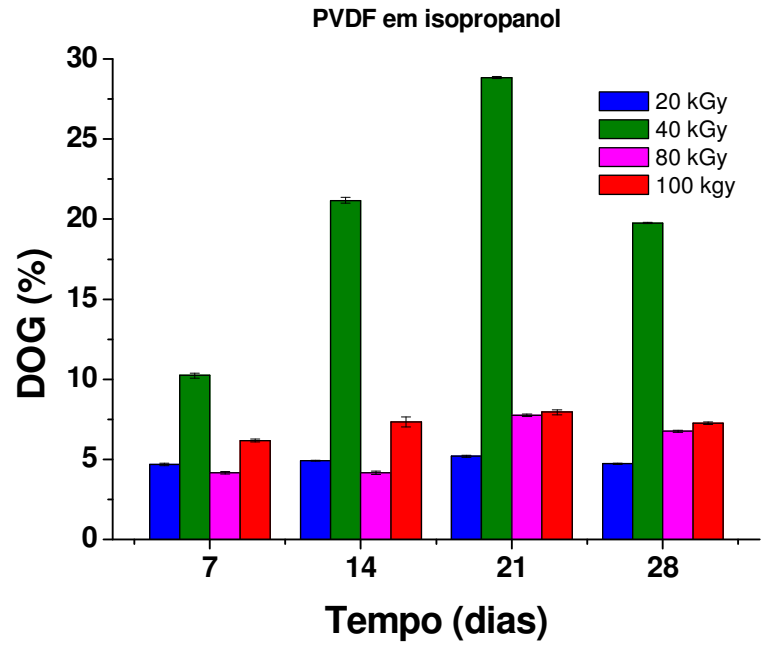

(b)

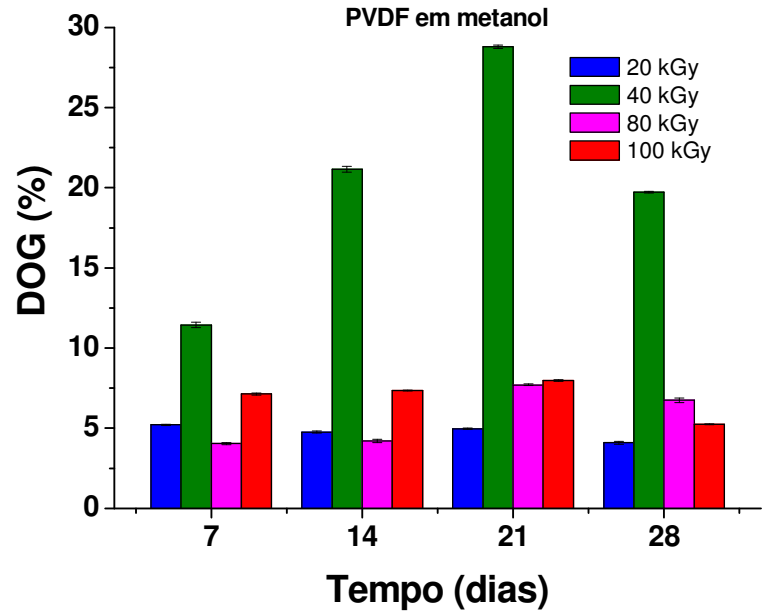

(c)

FIGURA 20: Grau de enxertia (DOG) para os filmes de PVDF (a) em tolueno, (b) em isopropanol e (c) em metanol. 


\subsection{FTIR}

Para confirmar a presença de poliestireno enxertado foi também utilizada a técnica de espectroscopia no infravermelho. Os filmes de PVDF, ETFE, PFA, PTFE e FEP enxertados apresentaram comportamento bastante similar por meio desta técnica, e por esse motivo, serão apresentados para discussão os resultados obtidos para o ETFE. A enxertia do estireno, nos diversos filmes estudados nos solventes tolueno, isopropanol e metanol, foi comprovada por espectroscopia no infravermelho. A FIG 21 mostra os espectros do filme de ETFE nas doses de 20,40, 80 e 100 kGy, no solvente tolueno. Todos os filmes estudados nas diferentes doses e diferentes solventes apresentaram novas bandas características do estireno enxertado entre $3100-3000 \mathrm{~cm}^{-1}$, devido ao estiramento $\mathrm{C}-\mathrm{H}$ do anel aromático. Em $2920 \mathrm{~cm}^{-1}$, encontra-se uma banda referente ao estiramento assimétrico do $\mathrm{CH}_{2}$ alifático do estireno enxertado e em $2850 \mathrm{~cm}^{-1}$, devido ao estiramento simétrico do $\mathrm{CH}_{2}$ alifático do estireno enxertado. As bandas entre 1490 e $1460 \mathrm{~cm}^{-1}$, são atribuídas à deformação no plano do esqueleto $\mathrm{C}=\mathrm{C}$ do estireno enxertado e em $1600 \mathrm{~cm}^{-1}$, atribuídas à deformação do esqueleto $\mathrm{C}=\mathrm{C}$, bandas harmônicas e de combinação atribuídas ao $\mathrm{C}-\mathrm{H}$ fora do plano são encontradas em torno de $1660-2000 \mathrm{~cm}^{-1}$, compatíveis com os resultados encontrados na literatura $[11,15,16,26,38,55,57]$. As bandas entre 3100 e $3000 \mathrm{~cm}^{-1}$ não foram observadas para os filmes de PVDF enxertados. 


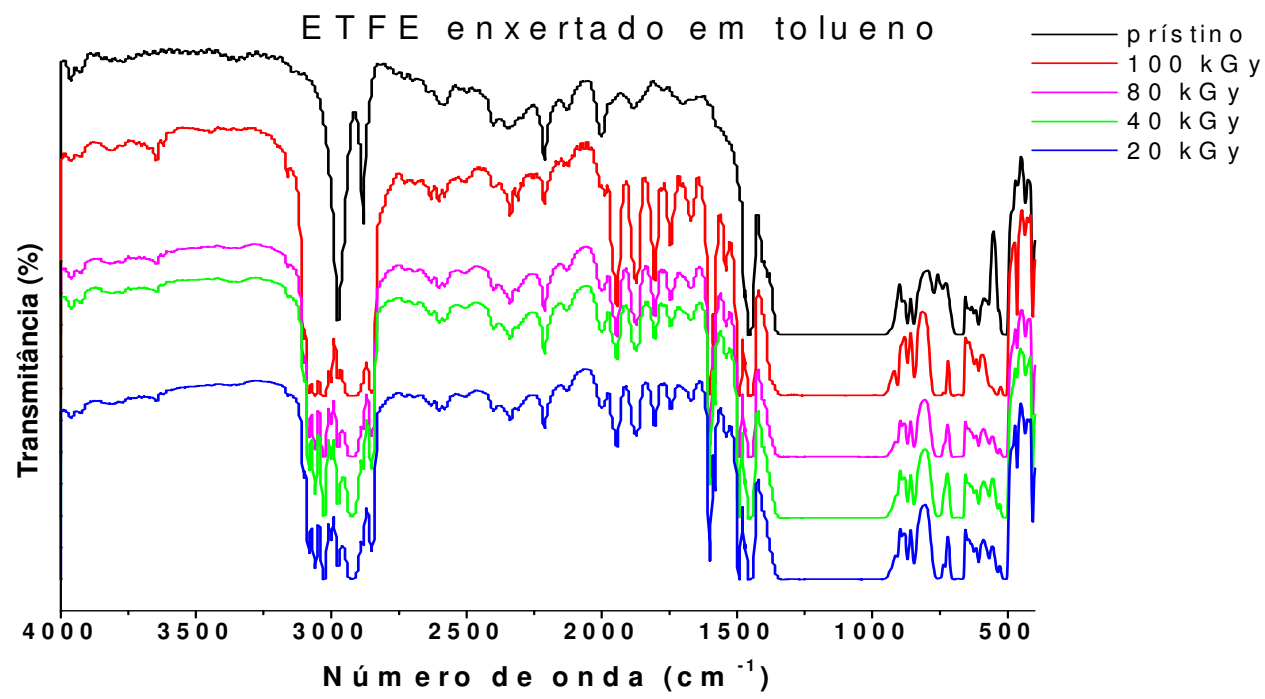

FIGURA 21: Espectros dos filmes de ETFE prístino e enxertados no solvente tolueno nas doses de 20 a 100 kGy.

\subsection{Microscopia eletrônica de varredura}

A verificação da morfologia do poliestireno enxertado foi realizada por MEV. Nas FIGs 22 e 23 podem ser observadas imagens de MEV da superfície de filmes de ETFE e Nafion ${ }^{\circledR}$ 115. Na FIG 22 estão apresentadas as micrografias referentes ao Nafion $^{\circledR}$ e aos filmes de ETFE prístino e irradiados com 20 e 100 kGy. Na FIG 23 as micrografias são das amostras enxertadas com tolueno a 20 e 100 kGy e destas mesmas amostras sulfonadas. As ampliações foram de $5000 \mathrm{X}$. 


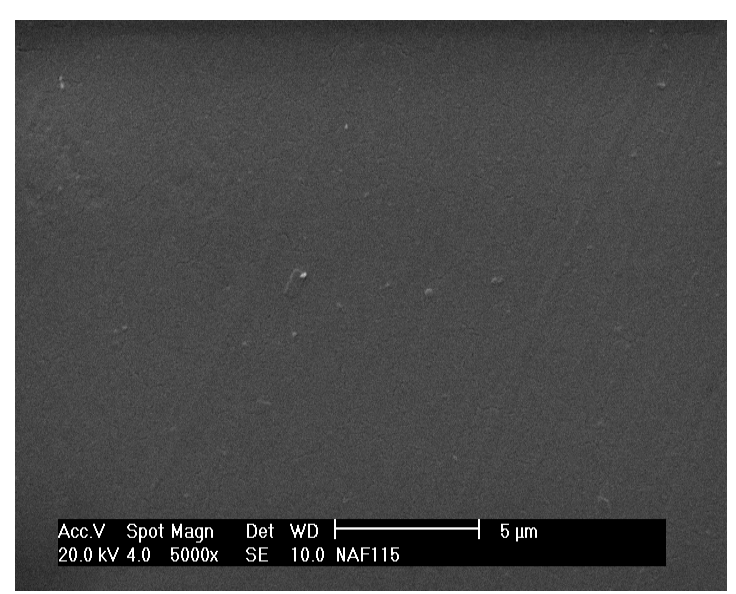

(a) Nafion ${ }^{\circledR} 115$

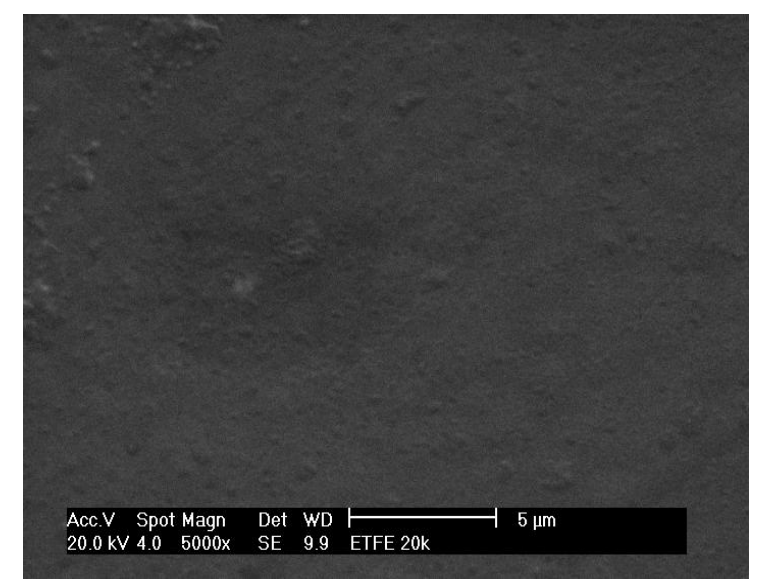

(c) sem monômero (20 kGy)

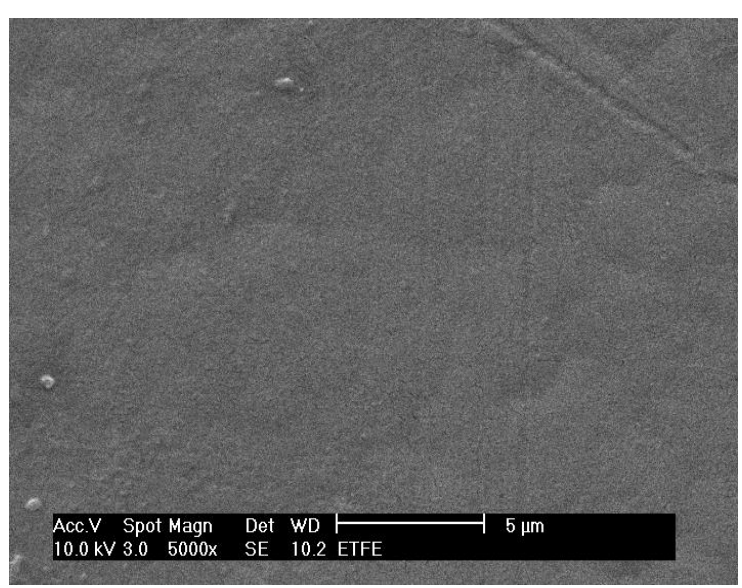

(b) ETFE prístino

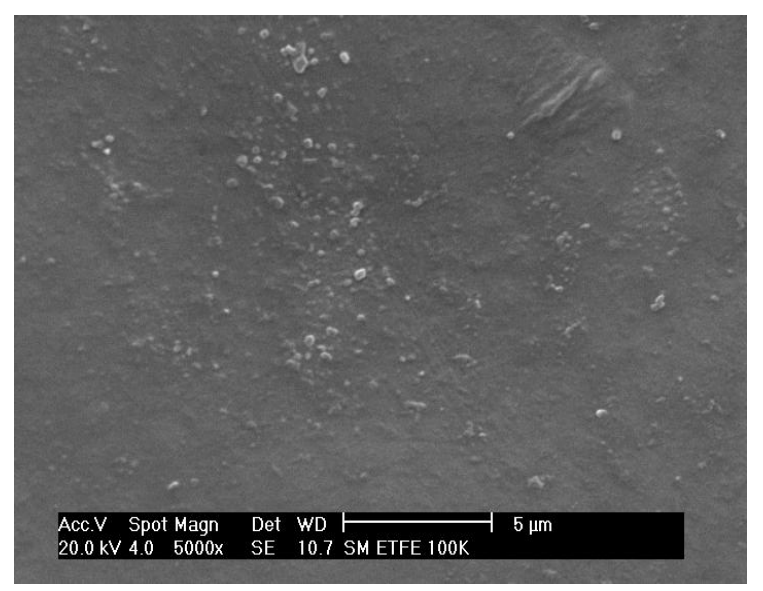

(d) sem monômero (100 kGy)

FIGURA 22: Imagens de MEV da superfície dos filmes Nafion ${ }^{\circledR} 115$ (a), ETFE prístino (b), irradiados a 20 (c) e 100 kGy (d). Ampliação de 5000 X.

As superfícies do Nafion $^{\circledR}$ e ETFE prístino e irradiado a 20 e 100 kGy são mostradas na FIG 22. A superfície do Nafion $^{\circledR}$ (FIG 22 a) é homogênea. No ETFE prístino (FIG 22 b) observa-se uma superfície ligeiramente mais rugosa e podem ser observados contornos de agregados cristalinos. Nos ETFE irradiados notam-se algumas diferenças: a amostra irradiada a 20 kGy apresenta uma superfície mais rugosa com picos e vales mais profundos porém no filme irradiado a 100 kGy são observados picos e vales ainda mais intensos e, ainda, alguma formação cristalina que se projeta da superfície. A diferença no grau de cristalinidade entre o polímero puro $\left(w_{c}=36 \%\right)$ e o irradiado $\left(w_{c}=48 \%\right)$ fica bastante evidente na imagem do filme irradiado a 100 kGy. 
Os filmes de FEP e PFA apresentaram morfologia de superfície similar aos filmes de ETFE e por esse motivo serão apresentadas para discussão as imagens dos filmes de ETFE enxertados em tolueno, metanol e isopropanol.

A morfologia dos enxertos mostrou-se dependente do solvente utilizado. As FIGs 23 a 25 mostram que a superfície dos filmes de ETFE estão totalmente recobertos por camadas de poliestireno.

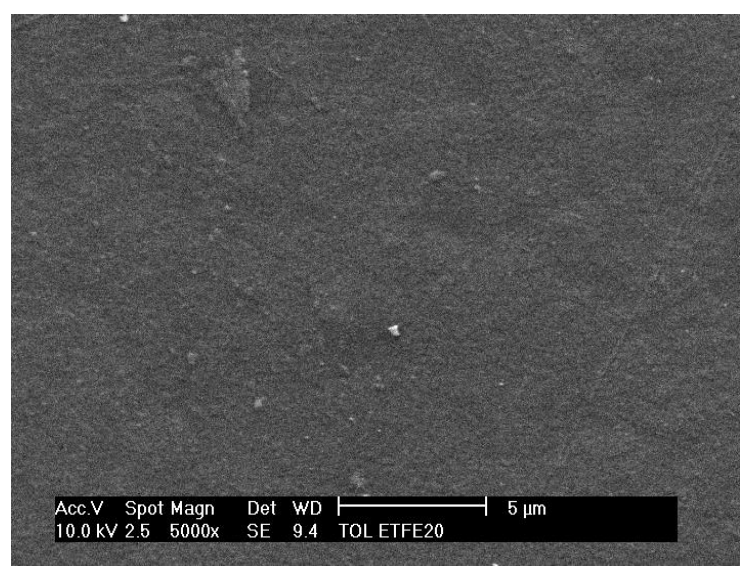

(a) Tolueno $20 \mathrm{kGy}$

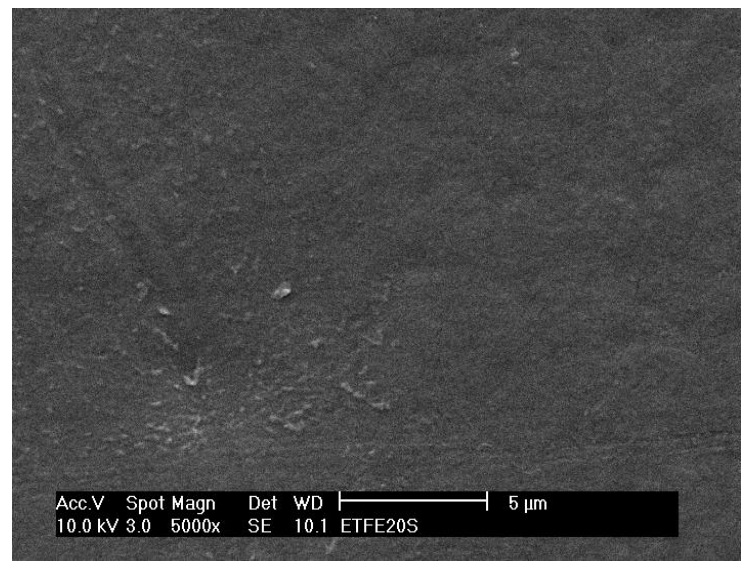

(c) Tolueno 20 kGy e sulfonado

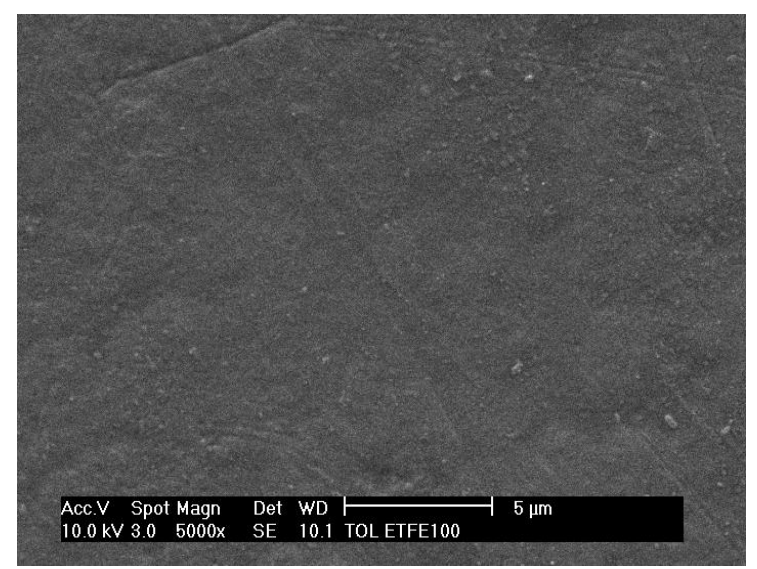

(b) Tolueno 100 kGy

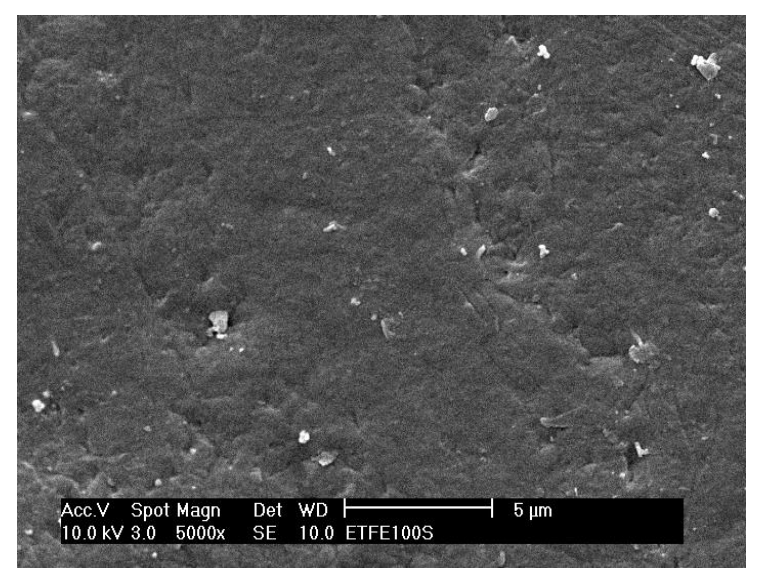

(d) Tolueno 100 kGy e sulfonado

FIGURA 23: Imagens de MEV da superfície de filmes de ETFE enxertados (a, b) e sulfonados (c, d) em tolueno 20 e 100 kGy. Ampliação de 5000 X.

$\mathrm{Na}$ presença de tolueno, a superfície do filme apresenta-se com rugosidades (FIGs 23a e 23b) como a morfologia verificada no ETFE prístino (FIG 22b). Observa-se também que a enxertia em metanol (FIG 24 a e b) apresentou um crescimento de cadeia esférico de dimensões menores que os enxertos em isopropanol (FIGs 25 a e b), com aglomerados de poliestireno. Na imagem do 
filme enxertado em metanol a 100 kGy (FIG 24b) são observadas micro fibrilas à direita da imagem. Estas micro fibrilas são também observadas nas imagens dos filmes de FEP e ETFE enxertados em metanol. Além disso, para ambos os solventes observam-se cavidades.

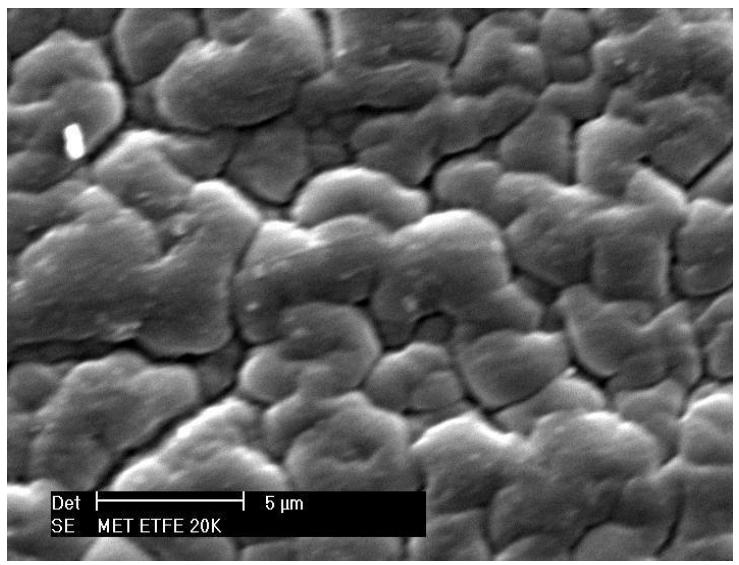

(a) Metanol 20 kGy

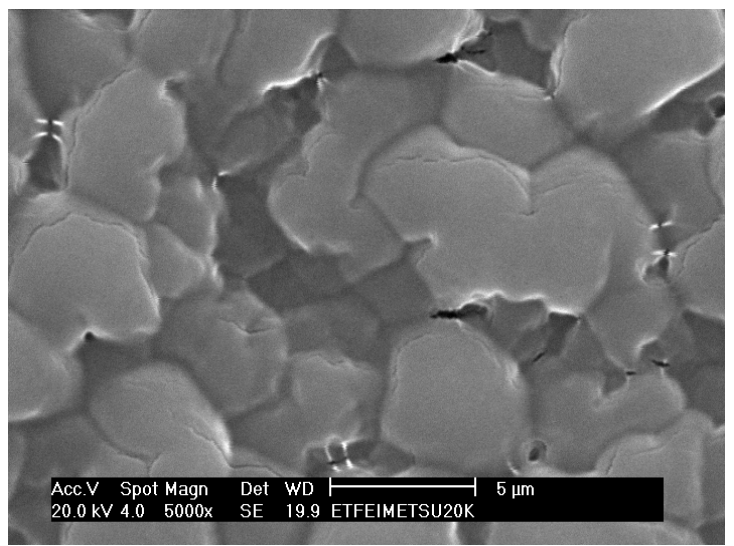

(c) Metanol 20 kGy e sulfonado

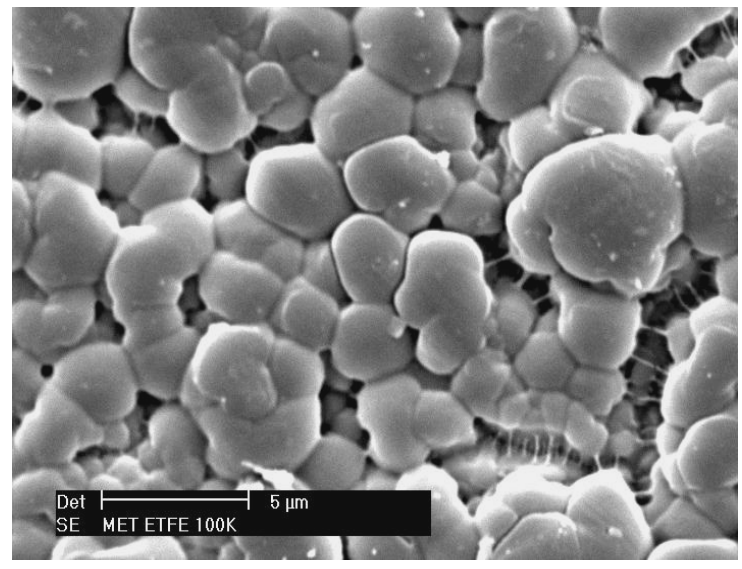

(b) Metanol $100 \mathrm{kGy}$

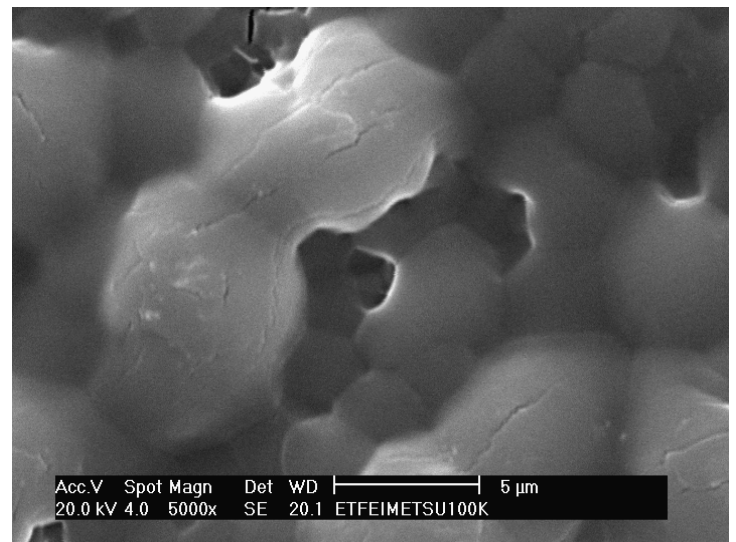

(d) Metanol 100 kGy e sulfonado

FIGURA 24: Imagens de MEV da superfície de filmes de ETFE enxertados ( $a, b)$ e/ou sulfonados (c, d) em metanol 20 e 100 kGy. Ampliação de 5000 X.

Para os filmes enxertados em tolueno, e posteriormente, sulfonados (FIGs $23 \mathrm{c}$ e d), as superfícies apresentaram-se rugosas. Já para os filmes enxertados em metanol (FIGs $24 \mathrm{c}$ e d) ou isopropanol (FIGs $25 \mathrm{c}$ e d) e posteriormente sulfonados, observam-se cavidades, trincas ou rachaduras indicando que o ácido clorosulfônico utilizado para sulfonar os grupos estirênicos enxertados pode ter fragilizado as camadas de poliestireno. 


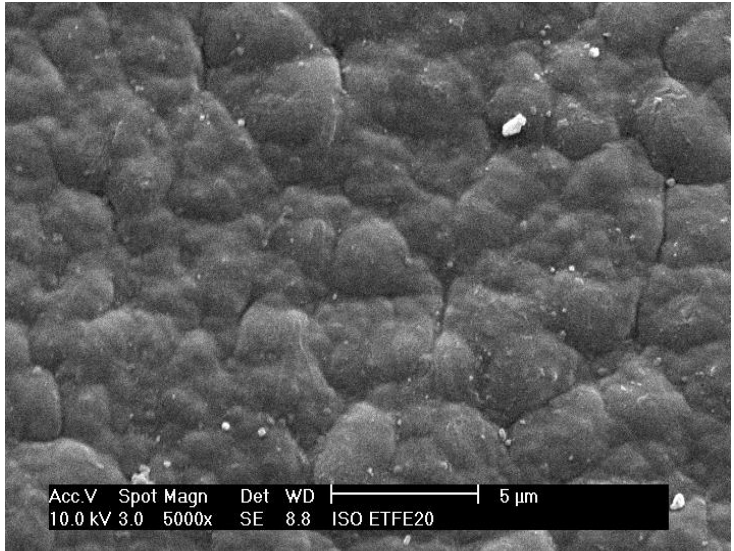

(a) Isopropanol 20 kGy

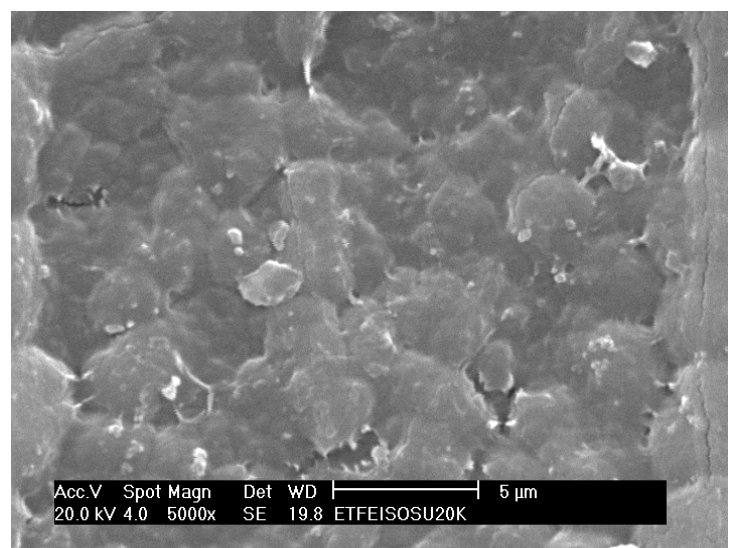

(c) Isopropanol 20 kGy e sulfonado

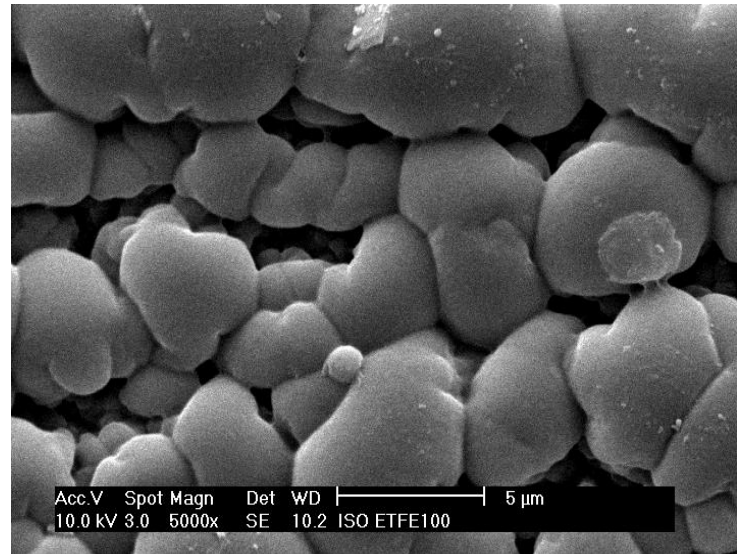

(b) Isopropanol 100 kGy

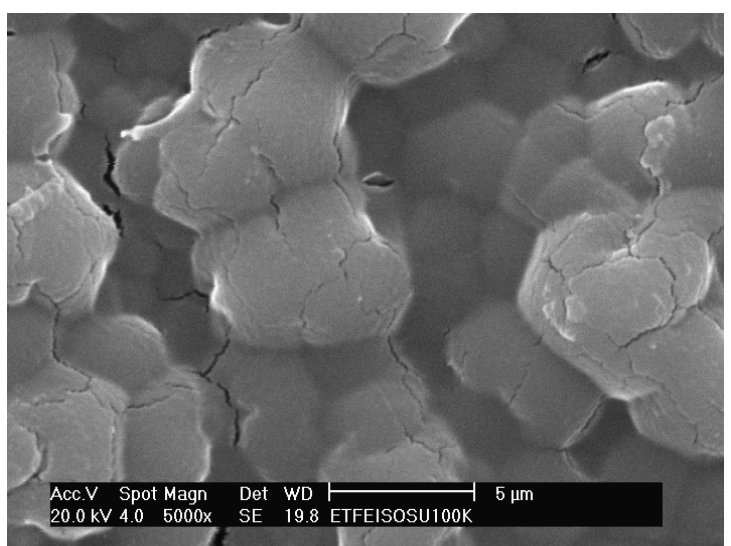

(d) Isopropanol 100 kGy e sulfonado

FIGURA 25: Imagens de MEV da superfície de filmes de ETFE enxertados (a, b) e/ou sulfonados (c, d) em isopropanol 20 e 100 kGy. Ampliação de $5000 \mathrm{X}$.

Quando se observam as micrografias considerando apenas o efeito da dose de irradiação constata-se que a morfologia das amostras não foi alterada pela dose de irradiação a qual o material foi submetido. Pois, para a reação de enxertia em tolueno a superfície é levemente rugosa independente da dose (FIGs 23 a e b). Para a reação de enxertia em metanol (FIGs 24 a e b) ou isopropanol (FIGs 25 a e b) a superfície é mais descontínua também independente da dose irradiada. Portanto, a dose de irradiação utilizada para as reações de enxertia não interfere significativamente na morfologia das amostras enquanto que o tipo do solvente utilizado provoca diferentes perfis morfológicos nestas superfícies. Este fato está de acordo com o reportado na literatura [18,60]. 
As imagens das superfícies dos filmes de PTFE apresentaram-se bastante diferenciadas (FIGs 26 a 29). A superfície do PTFE prístino mostrou-se lisa (FIG 26a) sendo observadas algumas marcas de dobra no filme.

Nos filmes irradiados nota-se diferenças significativas: os filmes irradiado a 20 e 100 kGy apresentaram uma superfície bastante rugosa (FIGs 26 a e b). A diferença no grau de cristalinidade entre o polímero puro ( $\left.w_{c}=46 \%\right)$ e 0 irradiado $\left(w_{c}=91 \%\right)$ fica bastante evidente nas imagens. Isso comprova a afirmação da alta cristalinidade dos filmes de PTFE irradiados discutida no item 5.1 .

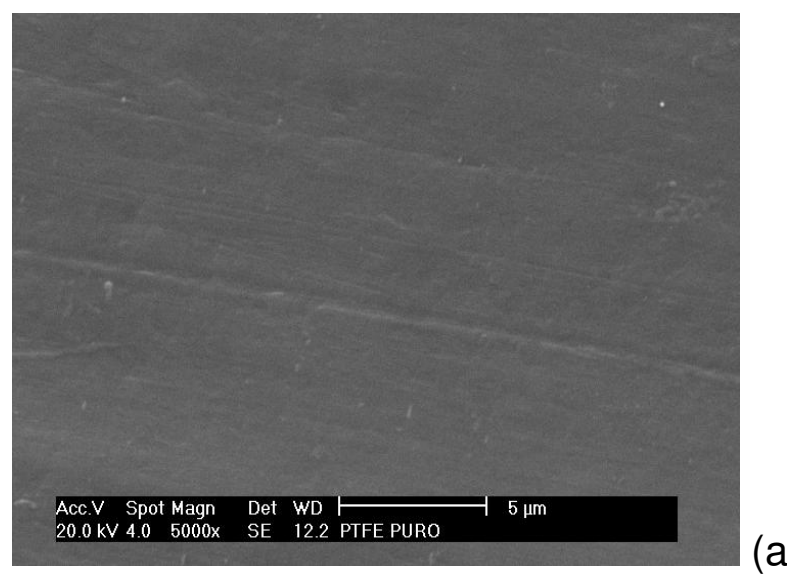

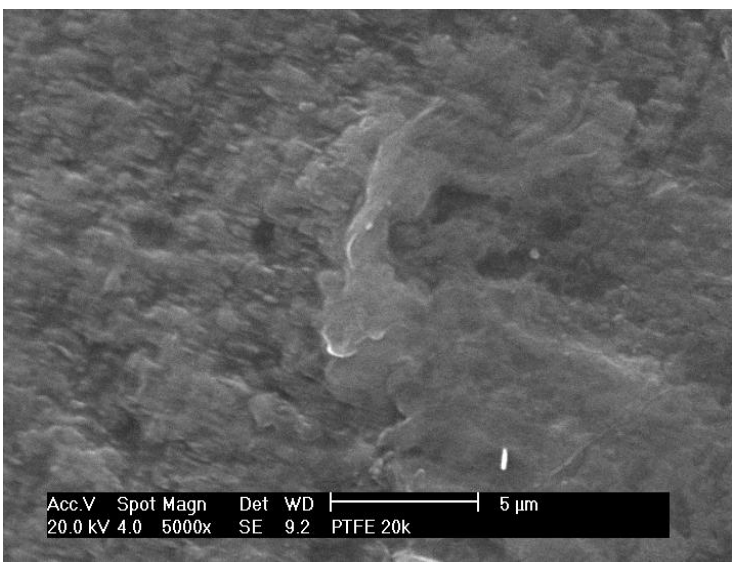

(b) sem monômero (20 kGy)

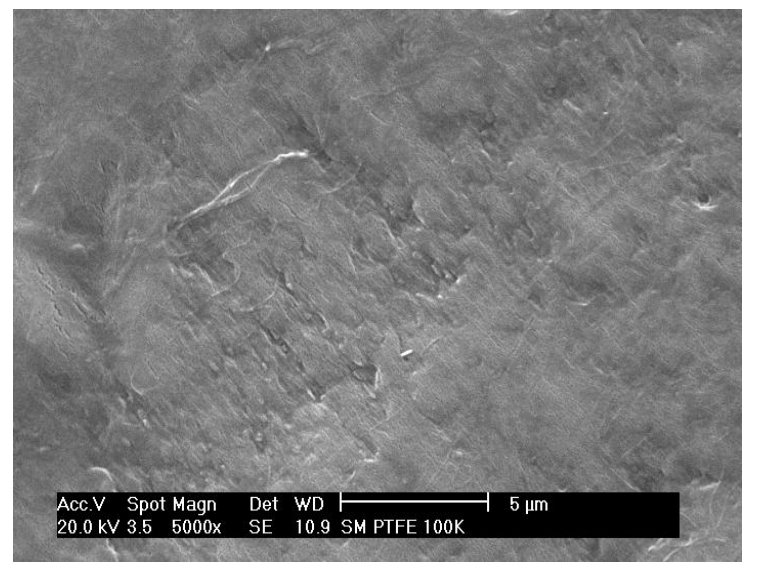

(c) sem monômero (100 kGy)

FIGURA 26: Imagens de MEV da superfície de filmes de PTFE prístino (a) e irradiado (a 20 e 100 kGy). Ampliação de 5000 X. 
As micrografias referentes à enxertia dos filmes de PTFE nos solventes tolueno, isopropanol e metanol (FIGs 27 a 29) mostraram imagens das cadeias de poliestireno enxertadas superficialmente. As enxertias tiveram rendimentos muito baixos e nas imagens da superfície observam-se aglomerados muito pequenos de poliestireno.

Nas micrografias dos filmes enxertados em tolueno (FIGs 27 a e b) verificam-se enxertos superficiais. Provavelmente o solvente não intumesceu o filme para que a enxertia fosse mais homogênea como o que aconteceu nos filmes de ETFE, FEP e PFA.

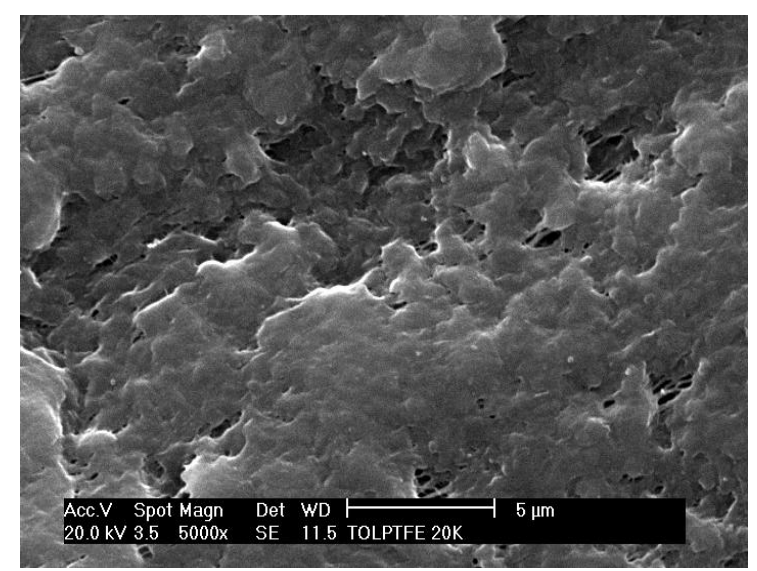

(a) Tolueno 20 kGy

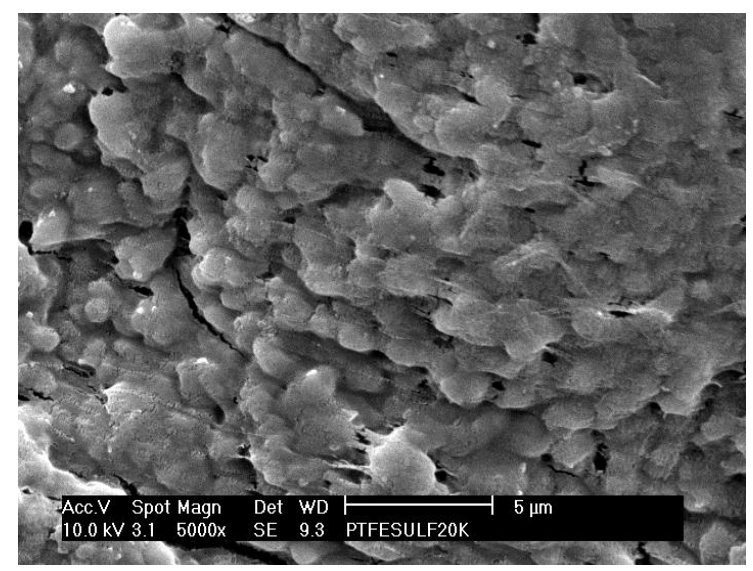

(c) Tolueno 20 kGy e sulfonado

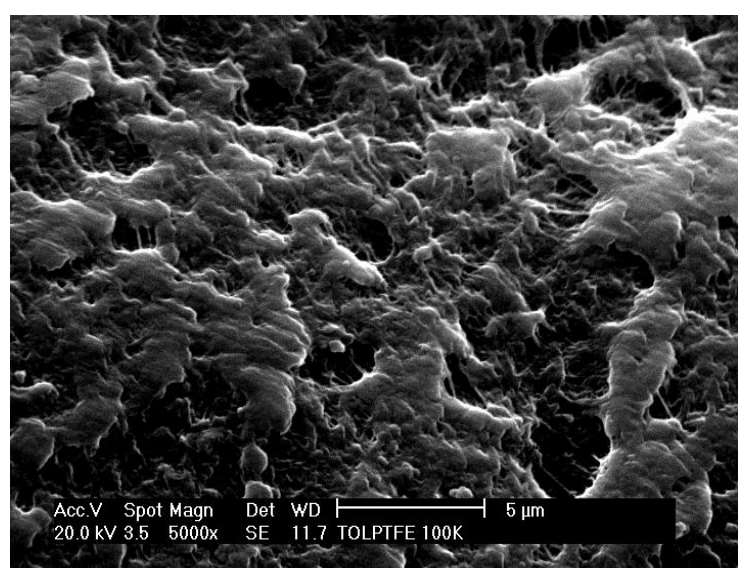

(b) Tolueno 100 kGy

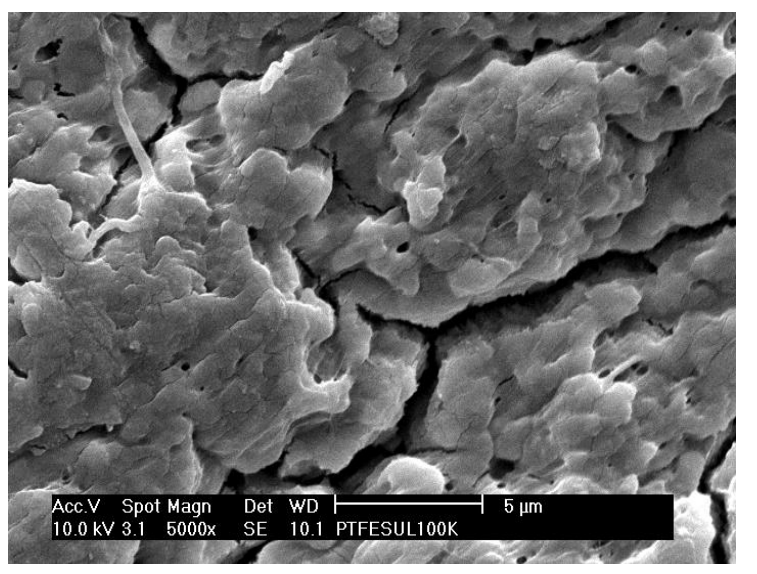

(d) Tolueno 100 kGy e sulfonado

FIGURA 27: Imagens de MEV da superfície de filmes de PTFE enxertados ( $a, b)$ e/ou sulfonados (c, d) em tolueno 20 e 100 kGy. Ampliação de $5000 \mathrm{X}$. 
Nos filmes enxertados em metanol (FIG 28 a e b) e isopropanol (FIG 29 a e b) são observados aglomerados esféricos de poliestireno com muitas fibrilas ligando estas pequenas esferas.

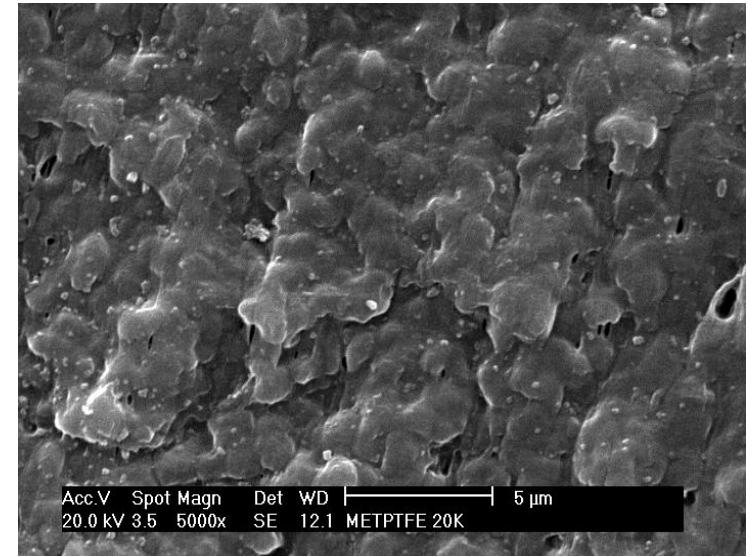

(a) Metanol 20 kGy

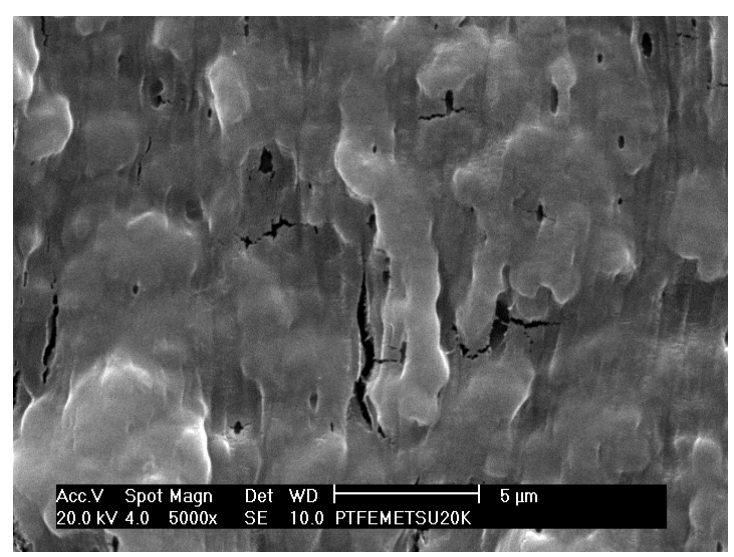

(c) Metanol 20 kGy e sulfonado

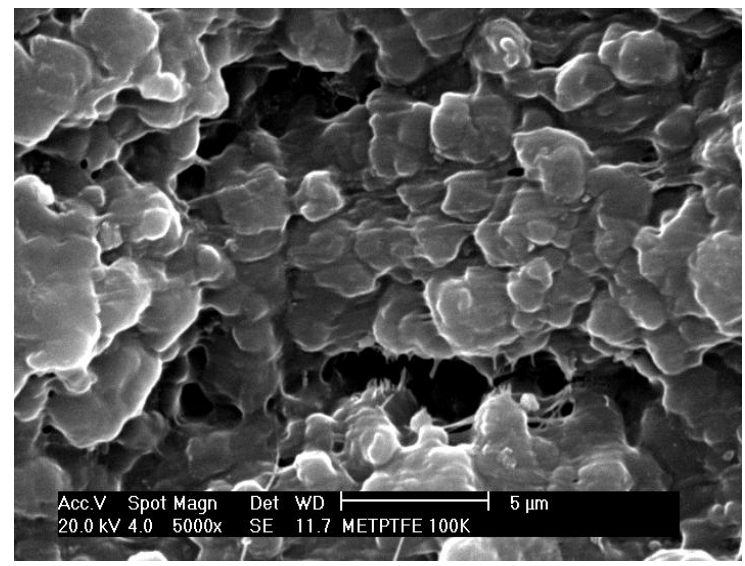

(b) Metanol 100 kGy

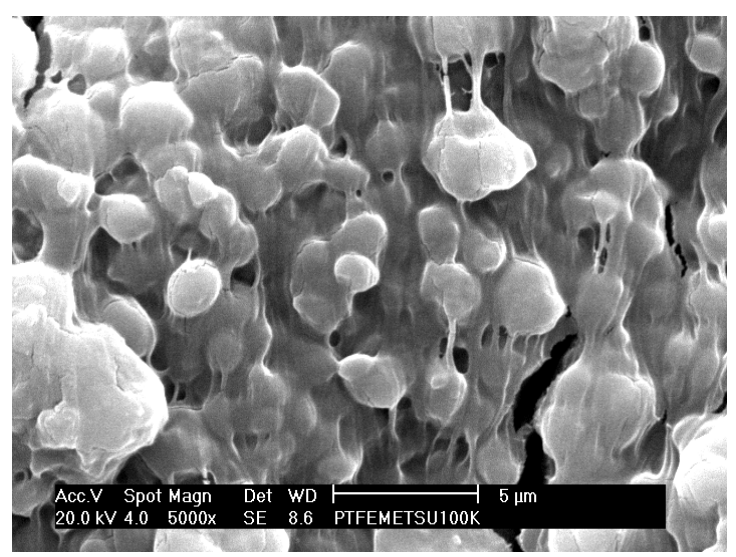

(d) Metanol 100 kGy e sulfonado

FIGURA 28: Imagens de MEV da superfície de filmes de PTFE enxertados (a, b) e/ou sulfonados (c, d) em metanol 20 e 100 kGy. Ampliação de $5000 \mathrm{X}$.

Já para os filmes enxertados em tolueno (FIGs 27c e d), metanol (FIGs 28 c e d) ou isopropanol (FIGs 29 c e d) e, posteriormente, sulfonados, observamse cavidades, trincas ou rachaduras indicando que o ácido clorosulfônico utilizado para sulfonar os grupos estirênicos enxertados pode ter fragilizado as camadas de poliestireno. 


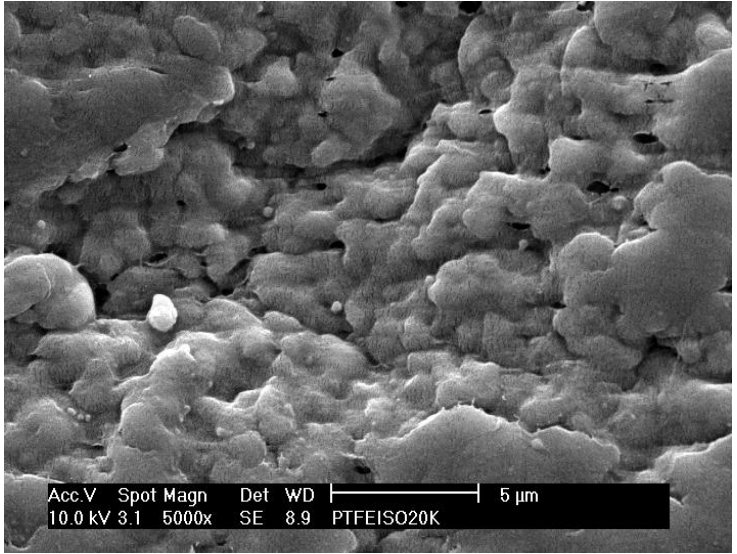

(a) Isopropanol 20 kGy

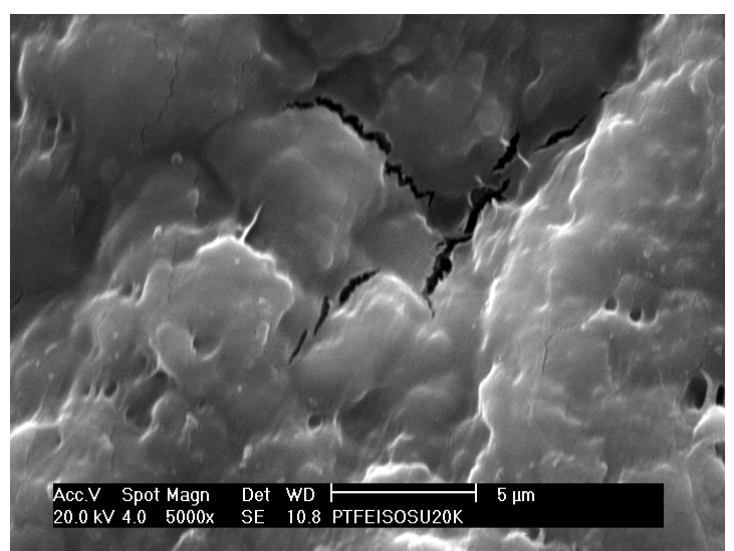

(c) Isopropanol 20 kGy e sulfonado

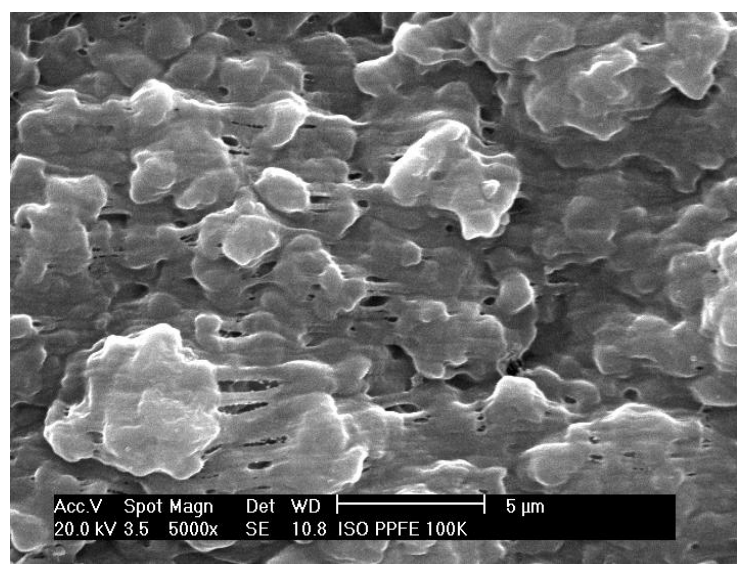

(b) Isopropanol 100 kGy

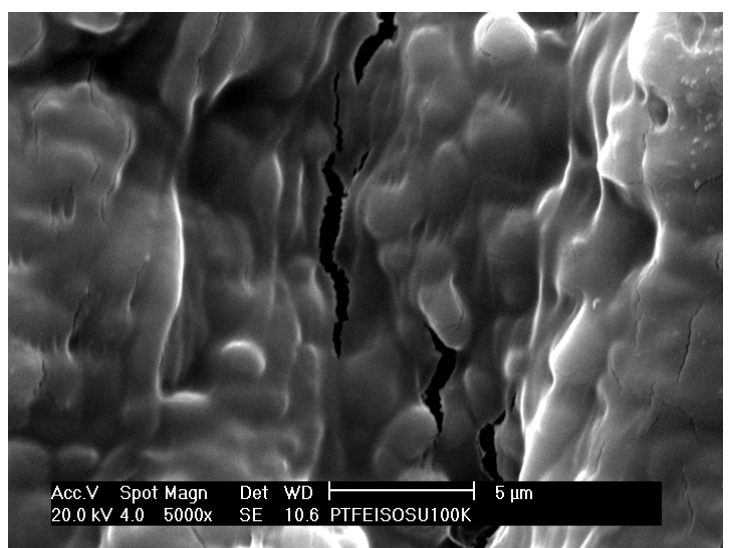

(d) Isopropanol 100 kGy e sulfonado

FIGURA 29: Imagens de MEV da superfície de filmes de PTFE enxertados (a, b) e/ou sulfonados (c, d) em isopropanol 20 e 100 kGy. Ampliação de $5000 X$.

As imagens das superfícies dos filmes de PVDF apresentaram-se também bastante diferenciadas (FIG 30). A superfície do PVDF prístino (FIG 30a) apresentou imperfeições provavelmente provenientes do procedimento de obtenção dos filmes que foi por prensagem dos grãos.

A imagem do filme de PVDF enxertado em tolueno a $20 \mathrm{kGy}$ mostrou uma superfície bastante rugosa (FIG 30b). No filme enxertado em metanol (FIG 30 c) são observados pequenos blocos de poliestireno. A imagem do PVDF enxertado em isopropanol a 20 kGy (FIG 30 d) mostra blocos de poliestireno bem definidos porém o formato não é esférico como o observado nos outros filmes. 


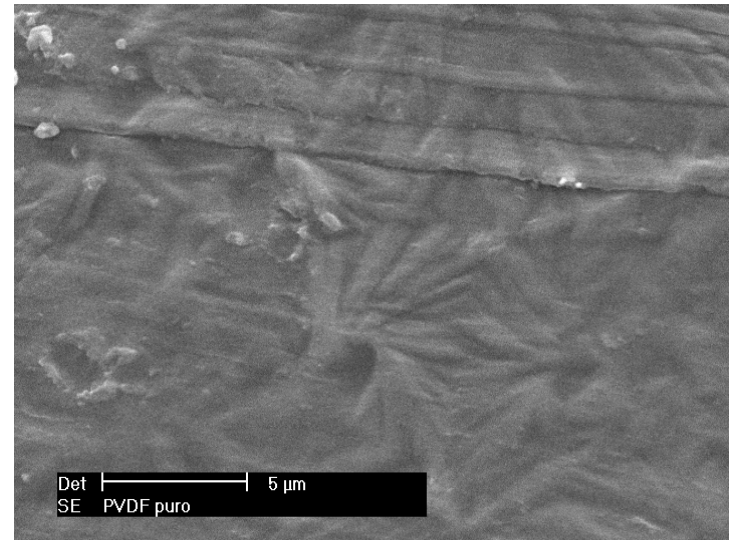

(a) prístino

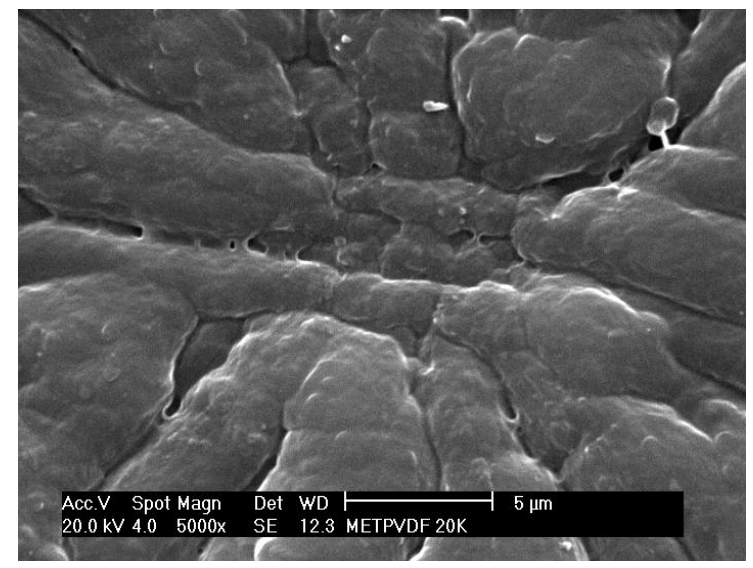

(c) Metanol 20 kGy

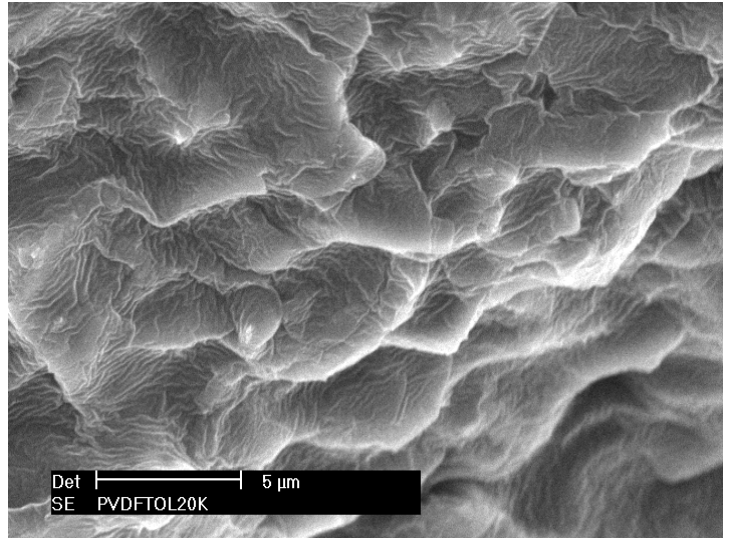

(b) Tolueno 20 kGy

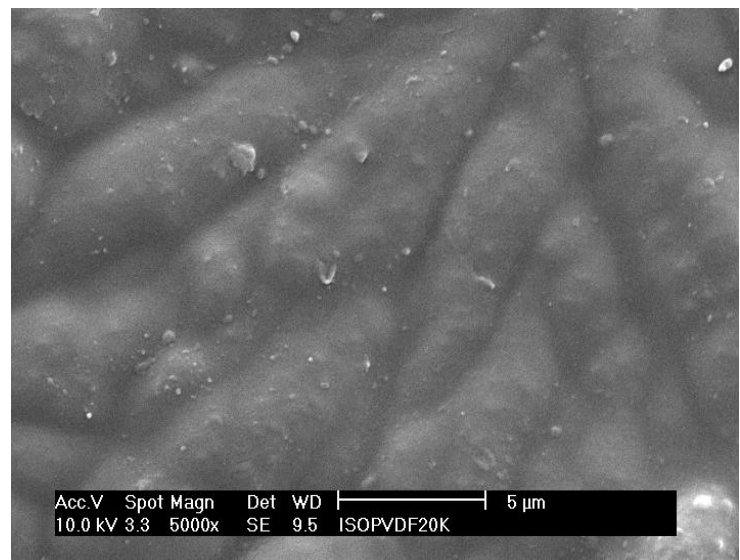

(d) Isopropanol 20 kGy

FIGURA 30: Imagens de MEV da superfície de filmes de PVDF prístino (a) e enxertado a $20 \mathrm{kGy}$ nos solventes (b) tolueno, (c) metanol e (d) isopropanol. Ampliação de $5000 \mathrm{X}$.

A superfície da fratura dos filmes de ETFE e Nafion ${ }^{\circledR}$ também foi investigada. Os filmes de Nafion ${ }^{\circledR}$ e ETFE sulfonados após enxertia em tolueno e metanol foram fraturados em nitrogênio liquido. Os filmes prístino e enxertados em tolueno, metanol e isopropanol não possibilitaram a fratura em nitrogênio e foram cortados. As ampliações foram entre 500 X e 4000X.

A FIG 31 mostra as superfícies da fratura dos filmes Nafion ${ }^{\circledR}$ e ETFE prístino. As imagens do Nafion $^{\circledR}$ FIG 31a (ampliação de 500X) e 31b (ampliação de 5000X) mostram a superfície homogênea do filme. As estrias observadas são provenientes da fratura do filme. Nas imagens do ETFE prístino FIGs 31c (ampliação 1000X) e 31d (ampliação 3000X) são observados apenas o esmagamento provocado pelo corte mecânico. 


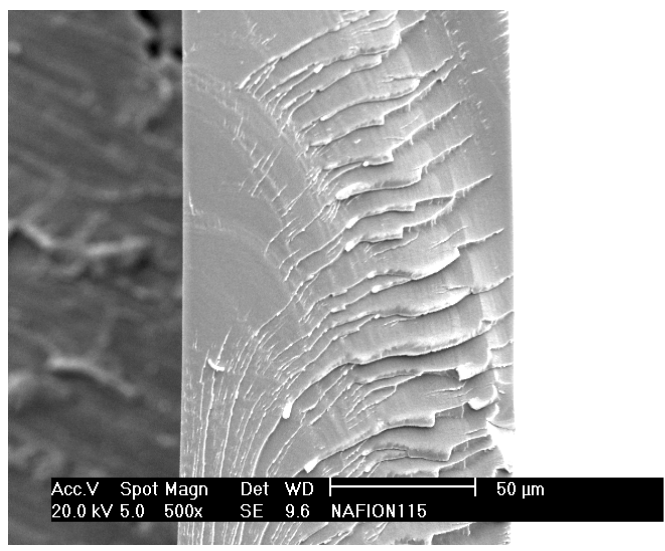

(a)
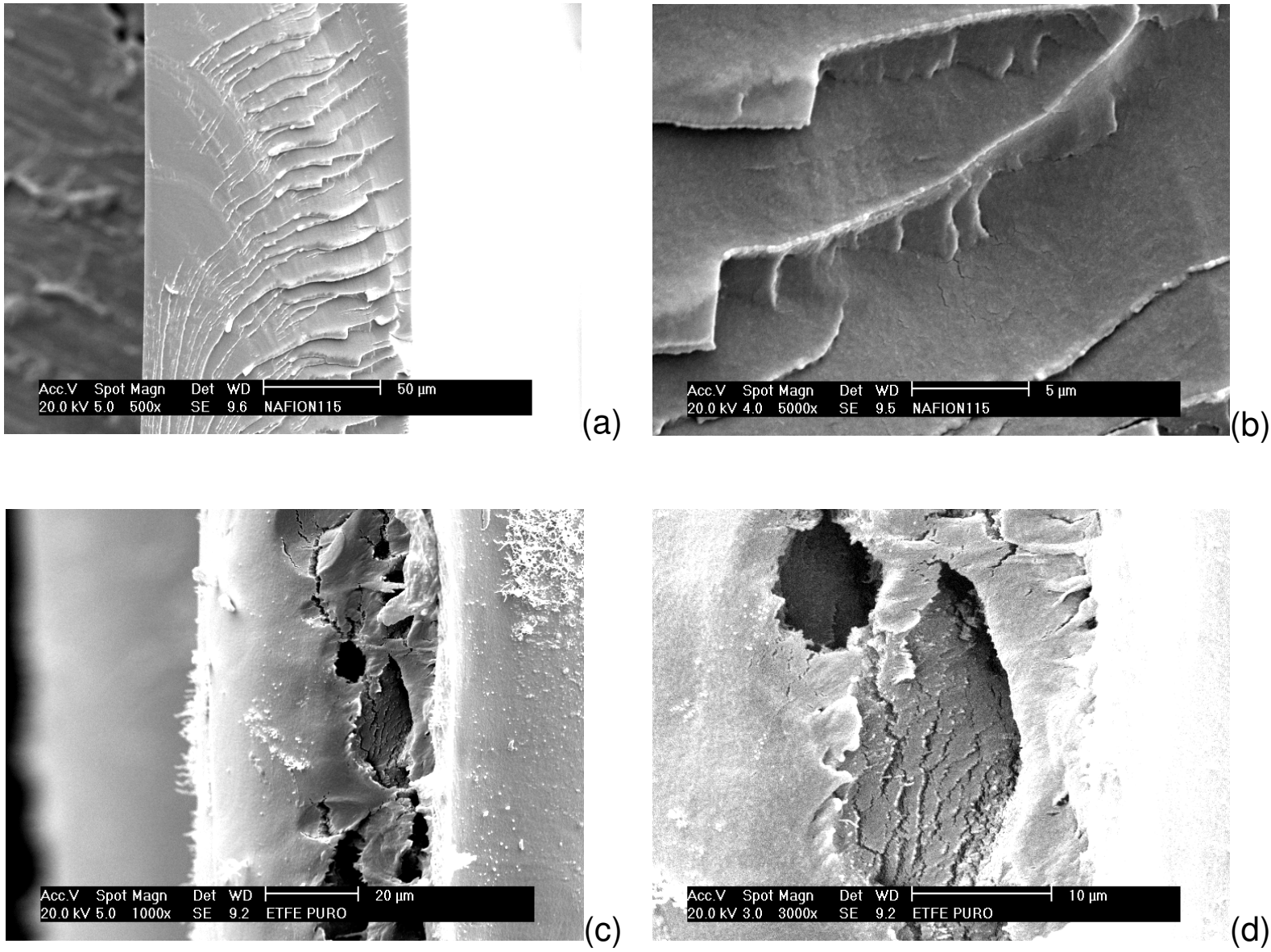

(d)

FIGURA 31: Imagens de MEV da superfície de fratura dos filmes $\operatorname{Nafion}^{\circledR}(a, b)$ e ETFE (c, d) prístino.

As FIGs 32a, 32c e 32e com ampliação de 500X, mostram imagens laterais dos filmes ETFE enxertados em tolueno, isopropanol e metanol respectivamente. Se observarmos os lados esquerdo e direito da FIG 32a poderemos supor uma heterogeneidade da enxertia. Nas FIGs 32b (enxertado em tolueno, ampliação de 5000X), 32d (enxertado em isopropanol, ampliação de 5000X) e $32 f$ (enxertado em metanol, ampliação de 4000X) embora haja forte influencia do corte mecânico dessas amostras, nota-se a heterogeneidade da enxertia. 

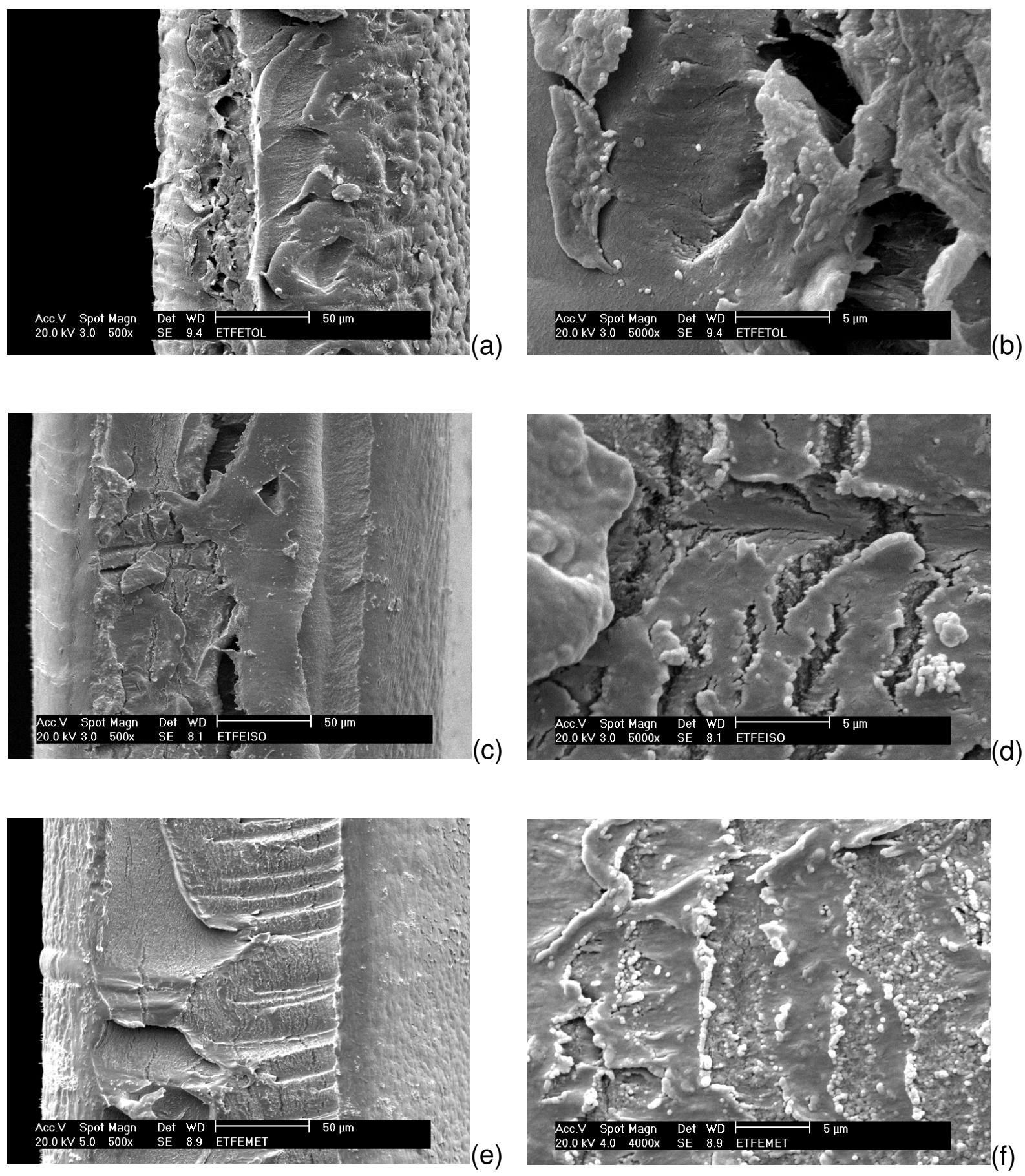

FIGURA 32: Imagens de MEV da superfície de fratura dos filmes de ETFE enxertados em tolueno ( $a, b)$, isopropanol $(c, d)$ e metanol (e, f). Fratura mecânica.

As FIGs 33a a 33d mostram as imagens da superfície de fratura do filme de ETFE enxertado em tolueno e sulfonado. Na figura 33b (ampliação de 500X) pode-se observar que as imagens da enxertia do lado esquerdo e direito 
são diferentes. No lado esquerdo FIG 33a (ampliação de 4000X) parece haver maior penetração dos enxertos. No lado direito, FIG 33c (ampliação de 4000X) parece haver uma superfície ondulada. Na FIG 33d (ampliação de 4000X) a observação da não homogeneidade da enxertia fica bastante evidente pois é possível observar os enxertos de poliestireno de tamanhos diferentes.

Nas FIGs 33e a 33h são mostradas as imagens da superfície de fratura do filme de ETFE enxertado em metanol e sulfonado. Na figura $33 f$ (ampliação de 500X) pode-se observar que a enxertia do lado esquerdo e direito são diferentes. As superfícies à esquerda FIG 33e (ampliação de 4000X) e à direita FIG $33 \mathrm{~g}$ parecem ser heterogêneas. A FIG 33h (ampliação de 4000X) revela uma superfície mais homogênea em contraste com uma mais heterogênea sendo possível observar claramente do lado esquerdo da imagem a fratura do filme. 


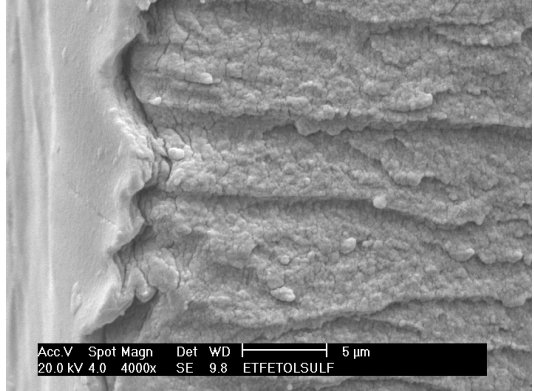

(a)

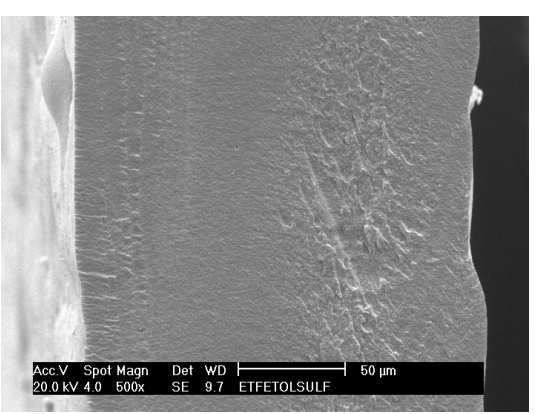

(b)

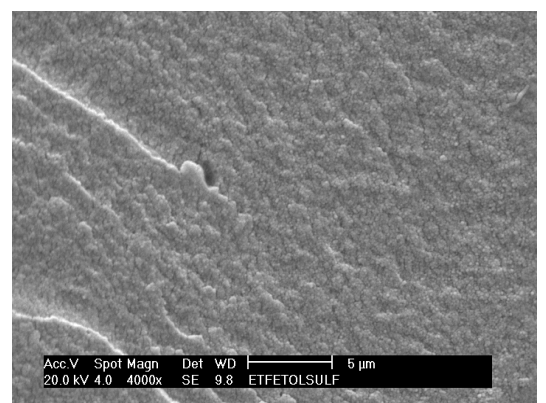

(d)

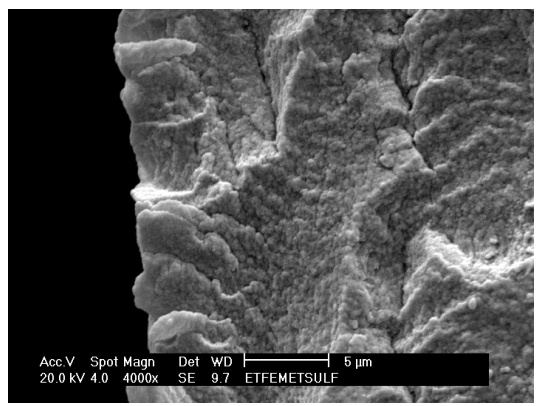

(e)

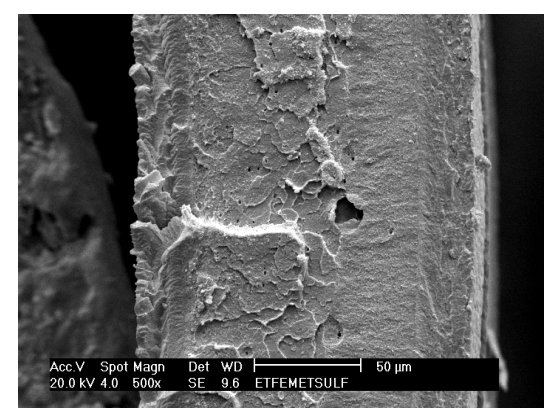

(f)

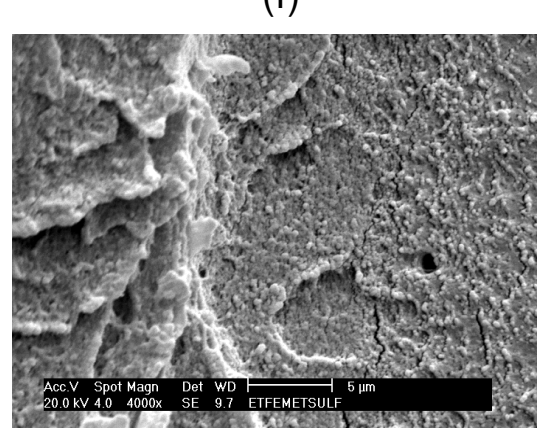

(h)

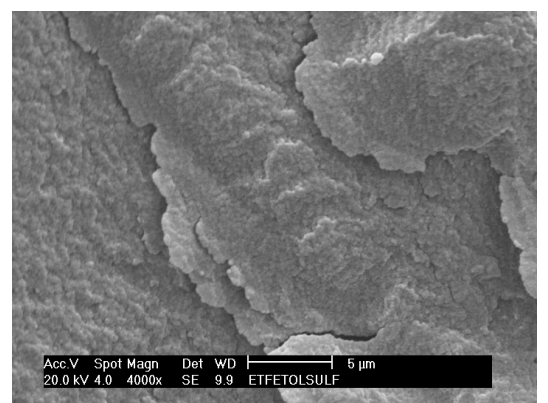

(c)

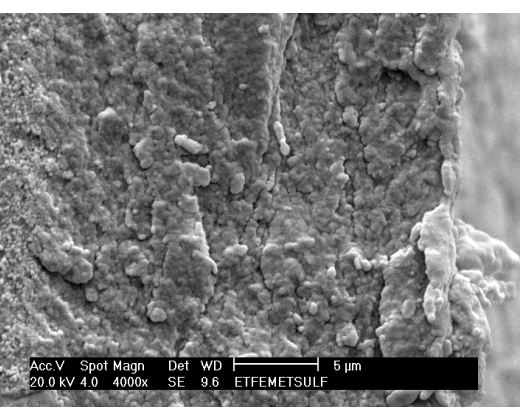

(g)

FIGURA 33: Imagens de MEV da superfície de fratura dos filmes de ETFE enxertados em tolueno (a-d) e metanol (e-h) e, posteriormente, sulfonados. Fratura em nitrogênio liquido.

As imagens das FIGs 32 e 33 sugerem, portanto que a enxertia nos filmes não é homogênea e tal observação pode ser estendida para todos os filmes estudados. 


\subsection{Efeito do solvente do estireno na enxertia}

Para que a reação de enxertia seja realizada com sucesso um dos parâmetros fundamentais é o tipo de solvente utilizado. O solvente além de diluir o estireno deve promover o inchamento do polímero permitindo o acesso do estireno aos sítios ativos criados pela irradiação. No caso dos polímeros fluorados o solvente deve melhorar o contato entre as fases apesar de não promover o inchamento da matriz. O resultado da enxertia não depende somente da dose de irradiação, mas também da difusão do estireno na matriz polimérica decorrente do intumescimento provocado pelo solvente. Após a irradiação as soluções estireno/isopropanol e estireno/metanol apresentaram maior viscosidade à medida que se aumenta a dose de irradiação, ao contrário da solução estireno/tolueno que não se observou qualquer mudança na viscosidade. Nos filmes de ETFE, por exemplo, maiores rendimentos de enxertia foram de forma geral bem menores do que em tolueno com a exceção notável das soluções contendo isopropanol ou metanol a 40 kGy.

Nos filmes de FEP, PFA, PTFE e PVDF, a maior enxertia também foi favorecida nas soluções contendo tolueno, ou seja, as maiores viscosidades encontradas nas soluções contendo isopropanol ou metanol desfavorecem a difusão do monômero aos sítios ativos. Para todos os filmes estudados nas soluções contendo tolueno foi observado que os maiores rendimentos aconteceram com a dose de 100 kGy. Os filmes enxertados em tolueno apresentam enxertias com valores médios maiores e mais homogêneos que os filmes enxertados nos diluentes isopropanol e metanol, com exceção das amostras irradiadas a $40 \mathrm{kGy}$ que tiveram um rendimento excepcional para o ETFE, diferentemente das demais irradiações nesses solventes. Não há ainda explicação para esse fenômeno.

Sob certas condições de reação, o intumescimento da matriz polimérica com um solvente deve facilitar o acesso do monômero aos sítios reativos formados durante a irradiação. O solvente não deve dissolver o polímero, pois altos rendimentos de enxertia dependem da heterogeneidade do sistema reacional para garantir lenta recombinação radicalar [75]. A incompatibilidade do solvente com a matriz polimérica reduz a mobilidade ou o crescimento das 
cadeias estendendo o tempo de vida dos radicais ocorrendo então um acúmulo de monômero preferencialmente na fase polimérica aumentando a concentração local do monômero e, portanto o rendimento de enxertia.

Outro aspecto interessante dos valores de enxertia nos diferentes diluentes é o fato de, em vários conjuntos de experimentos, haver um máximo em torno de 14 ou 21 dias e um decréscimo após estes períodos. Com essa observação pode-se especular uma possível fragilidade dos enxertos formados, pois essa perda de massa evidencia que houve decomposição do poliestireno formado.

Observou-se que o sistema estireno/tolueno mantém a viscosidade inalterada durante todo o período de enxertia enquanto que os sistemas estireno/isopropanol e estireno/metanol apresentam um grande aumento de viscosidade durante o período reacional. O aumento de viscosidade pode ser explicado pela homopolimerização do monômero estireno que é insolúvel no metanol e isopropanol. Esse aumento de viscosidade pode explicar o baixo rendimento de enxertia na maioria das reações em isopropanol e metanol estando de acordo com o observado por NASEF $[55,56,58]$.

As imagens de MEV também evidenciaram a influência dos diluentes estudados. Nos filmes enxertados em metanol e isopropanol há grande quantidade de homopolímero formado e as imagens mostraram enxertos com aglomerados de poliestireno na superfície dos filmes.

\subsection{Capacidade de troca iônica das membranas sulfonadas}

A introdução de grupos ácidos no grupo estirênico enxertado na membrana gera hidrofilicidade no polímero. Os grupos estirênicos enxertados foram sulfonados imergindo-se o filme enxertado em uma solução de ácido clorosulfônico em 1,2-dicloroetano (2:98 v/v) segundo outros autores [7, 24] nos tempos de 3, 4 e 5 horas. Os melhores valores de IEC foram obtidos após 4 horas de síntese. Com $5 \mathrm{~h}$ de reação todos os filmes sulfonados ficaram danificados. As TABs 8 a 11 descrevem os valores experimentais obtidos da IEC após a 
sulfonação dos filmes de ETFE, FEP, PFA e PTFE, respectivamente, quando expostos à mistura de clorosulfônico/dicloroetano no tempo de 4 horas. Os filmes de PVDF não resistiram à reação de sulfonação. A IEC teórica calculada pela equação (4) também é apresentada. A porcentagem de sulfonação da camada enxertada (S) foi calculada por uma regra de três. Sendo a capacidade de troca iônica teórica equivalente a $100 \%$ de sulfonação. A IEC do Nafion $^{\circledR}=0,9-1,1$ meq $g^{-1}[14]$.

Os dados experimentais para todos os filmes reportados nas TABs 8 a 11 quando comparados aos valores teóricos calculados mostram que os grupos estirênicos enxertados não foram totalmente sulfonados (coluna $S$ - rendimento da sulfonação). Tais resultados revelam a necessidade de se ajustar a concentração de ácido clorosulfônico para que mais grupos enxertados sejam sulfonados. A literatura sugere que a inabilidade do dicloroetano em intumescer a superfície do material enxertado é provavelmente o maior obstáculo e melhores rendimentos de sulfonação podem ser conseguidos a temperaturas acima de $50{ }^{\circ} \mathrm{C}[18,51]$. A solução de sulfonação utilizada intumesce pouco as membranas, mostrando que a penetração dos grupos sulfônicos é inadequada para atingir o estireno enxertado nas camadas mais internas. NASEF e SAIDI [71] utilizaram a concentração de 30:70 (v/v) à temperatura ambiente, obtiveram valores de grau de sulfonação em torno de $100 \%$. Também à temperatura ambiente, ASANO et al. [68] e SATO et al. [27] utilizaram concentração de 20:80 (v/v) obtendo valores de grau de sulfonação em torno de $100 \%$. Tendo em vista os resultados anteriores, as membranas preparadas para as medidas em célula foram sulfonadas a uma concentração de 20:80 (v/v), à temperatura ambiente.

A IEC é dependente do grau de enxertia e a capacidade de troca iônica das membranas pode ser controlada pela mudança no grau de enxertia [51]. 
TABELA 8: Capacidade de troca iônica (IEC) experimental e teórica para as membranas de ETFE no tempo de sulfonação de 4 horas. Doses de 20 a 100 kGy.

\begin{tabular}{|c|c|c|c|c|c|}
\hline Amostra/Solvente & $\begin{array}{l}\text { Dose } \\
\text { (kGy) }\end{array}$ & $\begin{array}{c}\text { DOG } \\
(\%) \\
\end{array}$ & $\begin{array}{c}\text { IEC }_{t} \\
\left(\text { mea g }^{-1}\right)\end{array}$ & $\begin{array}{c}\mathrm{IEC}_{\exp } \\
\left(\mathrm{meq} \mathrm{g}^{-1}\right)\end{array}$ & $\begin{array}{l}\mathrm{S} \\
(\%) \\
\end{array}$ \\
\hline \multirow{4}{*}{ ETFE/tolueno } & 20 & $30,7 \pm 2,1$ & 1,8 & 0,74 & 41 \\
\hline & 40 & $28,0 \pm 0,5$ & 1,8 & 1,0 & 55 \\
\hline & 80 & $50,8 \pm 3,0$ & 2,6 & 1,3 & 50 \\
\hline & 100 & $97,4 \pm 2,9$ & 3,3 & 2,2 & 67 \\
\hline \multirow{4}{*}{ ETFE/isopropanol } & 20 & $26,5 \pm 1,7$ & 1,7 & 0,57 & 33 \\
\hline & 40 & $150 \pm 11$ & 3,7 & * & * \\
\hline & 80 & $7,5 \pm 1,0$ & 0,70 & 0,14 & 20 \\
\hline & 100 & $7,2 \pm 0,4$ & 0,59 & 0,21 & 36 \\
\hline \multirow{4}{*}{ ETFE/metanol } & 20 & $7,9 \pm 0,4$ & 0,64 & 0,23 & 36 \\
\hline & 40 & $126 \pm 10$ & 3,6 & * & * \\
\hline & 80 & $18,8 \pm 1,2$ & 1,3 & 0,60 & 46 \\
\hline & 100 & $8,4 \pm 0,1$ & 0,68 & 0,22 & 32 \\
\hline
\end{tabular}

DOG: grau de enxertia IEC : capacidade de troca iônica teórica; IEC $_{\text {exp }}$ : capacidade de troca iônica experimental; S: rendimento de sulfonação da camada enxertada; *: degradação.

De modo geral os filmes enxertados em tolueno foram os que mostraram melhor rendimento de sulfonação. Provavelmente porque os enxertos podem estar melhor distribuídos na superfície dos filmes. 
TABELA 9: Capacidade de troca iônica (IEC) experimental e teórica para as membranas de FEP no tempo de sulfonação de 4 horas. Doses de 20 a 100 kGy.

\begin{tabular}{cccccc}
\hline Amostra/Solvente & $\begin{array}{c}\text { Dose } \\
(\mathrm{kGy})\end{array}$ & $\begin{array}{c}\mathrm{DOG} \\
(\%)\end{array}$ & $\begin{array}{c}\mathrm{IEC}_{\mathrm{t}} \\
\left(\mathrm{meq} \mathrm{g}^{-1}\right)\end{array}$ & $\begin{array}{c}\mathrm{IEC}_{\text {exp }} \\
\left(\mathrm{meq} \mathrm{g}^{-1}\right)\end{array}$ & $\begin{array}{c}\mathrm{S} \\
(\%)\end{array}$ \\
\hline \multirow{3}{*}{ FEP/tolueno } & 20 & $21,4 \pm 3,4$ & 1,4 & 0,94 & 67 \\
\cline { 2 - 6 } & 40 & $32,6 \pm 2,2$ & 1,9 & 1,3 & 68 \\
\cline { 2 - 6 } & 80 & $24,0 \pm 0,5$ & 1,6 & 0,87 & 54 \\
\hline \multirow{3}{*}{ FEP/isopropanol } & 100 & $39,0 \pm 1,3$ & 2,1 & 1,7 & 81 \\
\cline { 2 - 6 } & 20 & $21,3 \pm 0,5$ & 1,4 & 0,78 & 56 \\
\cline { 2 - 6 } & 80 & $15,4 \pm 1,6$ & 1,1 & 0,43 & 39 \\
\cline { 2 - 6 } & 100 & $8,3 \pm 0,9$ & 0,67 & 0,33 & 49 \\
\hline \multirow{3}{*}{ FEP/metanol } & 40 & $4,6 \pm 0,2$ & 0,39 & 0,23 & 59 \\
\cline { 2 - 6 } & 40 & $11,8 \pm 0,8$ & 0,90 & 0,35 & 39 \\
\cline { 2 - 6 } & 80 & $9,5 \pm 0,2$ & 0,75 & 0,36 & 48 \\
\cline { 2 - 6 } & 100 & $11,6 \pm 0,5$ & 0,89 & 0,39 & 44
\end{tabular}

DOG: grau de enxertia IEC : capacidade de troca iônica teórica; IEC $_{\text {exp }}$ : capacidade de troca iônica experimental; S: rendimento de sulfonação da camada enxertada.

Os filmes de FEP enxertados em metanol ou isopropanol tiveram rendimentos de sulfonação em torno de $50 \%$ e melhores rendimentos de sulfonação foram encontrados nos filmes enxertados em tolueno. 
TABELA 10: Capacidade de troca iônica (IEC) experimental e teórica para as membranas de PFA no tempo de sulfonação de 4 horas. Doses de 20 a 100 kGy.

\begin{tabular}{|c|c|c|c|c|c|}
\hline Amostra/Solvente & $\begin{array}{l}\text { Dose } \\
\text { (kGy) }\end{array}$ & $\begin{array}{c}\text { DOG } \\
(\%)\end{array}$ & $\begin{array}{c}\mathrm{IEC}_{\mathrm{t}} \\
\left(\text { meq g }^{-1}\right)\end{array}$ & $\begin{array}{c}\mathrm{IEC}_{\exp } \\
\left(\mathrm{meq} \mathrm{g}^{-1}\right)\end{array}$ & $\begin{array}{l}\text { S } \\
(\%)\end{array}$ \\
\hline \multirow{4}{*}{ PFA/tolueno } & 20 & $26,5 \pm 1,4$ & 1,7 & 1,2 & 71 \\
\hline & 40 & $37,5 \pm 2,4$ & 2,1 & 0,98 & 47 \\
\hline & 80 & $41,3 \pm 0,8$ & 2,2 & * & * \\
\hline & 100 & $74,4 \pm 3,6$ & 2,9 & * & * \\
\hline \multirow{4}{*}{ PFA/isopropanol } & 20 & $25,0 \pm 1,8$ & 1,6 & 1,0 & 62 \\
\hline & 40 & $52,6 \pm 3,7$ & 2,5 & 1,6 & 64 \\
\hline & 80 & $16,2 \pm 1,3$ & 1,2 & * & * \\
\hline & 100 & $10,3 \pm 0,5$ & 0,80 & * & * \\
\hline \multirow{4}{*}{ PFA/metanol } & 20 & $6,7 \pm 0,3$ & 0,55 & 0,33 & 60 \\
\hline & 40 & $15,7 \pm 1,2$ & 1,1 & 0,46 & 42 \\
\hline & 80 & $17,0 \pm 0,4$ & 1,2 & * & * \\
\hline & 100 & $18,7 \pm 1,3$ & 1,3 & * & * \\
\hline
\end{tabular}

DOG: grau de enxertia IEC $\mathrm{E}_{\mathrm{t}}$ : capacidade de troca iônica teórica; $\mathrm{IEC}_{\text {exp }}$ : capacidade de troca iônica experimental; S: rendimento de sulfonação da camada enxertada; *: degradação.

Os filmes de PFA enxertados nas doses de 80 e 100 kGy ficaram bastante frágeis não suportando a reação de sulfonação. 
TABELA 11: Capacidade de troca iônica (IEC) experimental e teórica para as membranas de PTFE no tempo de sulfonação de 4 horas. Doses de 20 a 100 kGy.

\begin{tabular}{cccccc}
\hline Amostra/Solvente & $\begin{array}{c}\text { Dose } \\
(\mathrm{kGy})\end{array}$ & $\begin{array}{c}\mathrm{DOG} \\
(\%)\end{array}$ & $\begin{array}{c}\mathrm{IEC}_{\mathrm{t}} \\
\left(\mathrm{meq} \mathrm{g}^{-1}\right)\end{array}$ & $\begin{array}{c}\mathrm{IEC}_{\exp } \\
\left(\mathrm{meq} \mathrm{g}^{-1}\right)\end{array}$ & $\begin{array}{c}\mathrm{S} \\
(\%)\end{array}$ \\
\hline \multirow{3}{*}{ PTFE/tolueno } & 20 & $9,5 \pm 0,5$ & 0,73 & 0,55 & 75 \\
\cline { 2 - 6 } & 40 & $12,3 \pm 0,4$ & 0,94 & 0,66 & 70 \\
\cline { 2 - 6 } & 80 & $16,2 \pm 0,3$ & 1,2 & 0,92 & 77 \\
\cline { 2 - 6 } & 100 & $18,5 \pm 0,4$ & 1,3 & 1,0 & 77 \\
\hline \multirow{3}{*}{ PTFE } & 20 & $6,1 \pm 0,3$ & 0,51 & 0,11 & 22 \\
\cline { 2 - 6 } isopropanol & 40 & $3,2 \pm 0,6$ & 0,44 & 0,06 & 14 \\
\cline { 2 - 6 } & 80 & $3,9 \pm 0,1$ & 0,33 & 0,04 & 12 \\
\hline \multirow{3}{*}{ PTFE /metanol } & 100 & $3,5 \pm 0,1$ & 0,30 & 0,08 & 27 \\
\cline { 2 - 6 } & 40 & $2,7 \pm 0,2$ & 0,25 & 0,11 & 44 \\
\cline { 2 - 6 } & 80 & $3,8 \pm 0,1$ & 0,33 & 0,11 & 33 \\
\cline { 2 - 6 } & 100 & $4,2 \pm 0,2$ & 0,36 & 0,16 & 44 \\
\hline
\end{tabular}

DOG: grau de enxertia IEC : capacidade de troca iônica teórica; $\mathrm{IEC}_{\text {exp }}$ : capacidade de troca iônica experimental; S: rendimento de sulfonação da camada enxertada.

No geral, a capacidade de troca iônica obtida para as membranas desenvolvidas neste trabalho foram superiores à do Nafion $^{\circledR}\left(0,9-1,1\right.$ meq $\left.^{-1}\right)$, sendo, portanto promissoras para os testes em célula a combustível. A exceção foram as membranas de PTFE que revelaram uma enxertia muito baixa devido à alta cristalinidade dos filmes irradiados.

Após a sulfonação as membranas de ETFE, FEP, PFA e PTFE foram caracterizadas por TG e DSC.

As curvas termogravimétricas das amostras sulfonadas, aqui representadas pelo ETFE enxertado a 20 kGy (FIG 34) nos solventes tolueno, isopropanol e metanol mostram 4 etapas de decomposição: 
Etapa 1: a perda de massa que começa em $40{ }^{\circ} \mathrm{C}$ e continua até $150{ }^{\circ} \mathrm{C}$ refere-se à evaporação da água residual da amostra com o inicio da perda dos grupos sulfônicos [76].

Etapa 2: a perda de massa entre 240 e $350{ }^{\circ} \mathrm{C}$ refere-se à perda dos grupos ácidos sulfônicos [77,78].

Etapa 3: a perda de massa entre 370 e $450{ }^{\circ} \mathrm{C}$ refere-se à perda de massa do estireno enxertado.

Etapa 4: a perda de massa entre 470 e $550{ }^{\circ} \mathrm{C}$ refere-se à perda de massa da matriz polimérica.

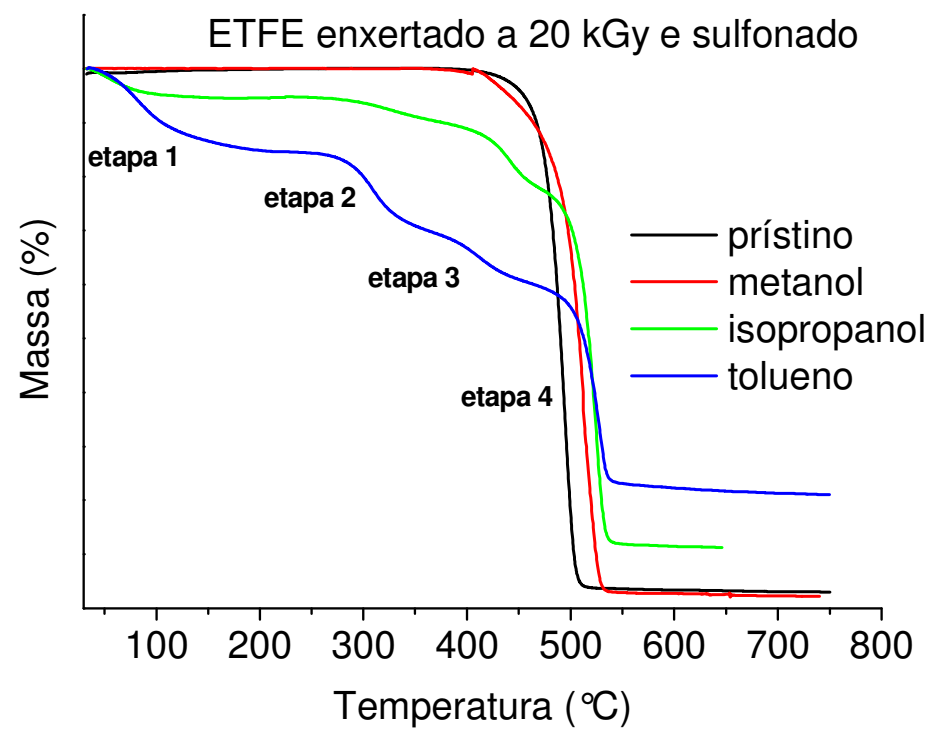

FIGURA 34: Curvas termogravimétricas do ETFE prístino, enxertado em tolueno, isopropanol e metanol na dose de $20 \mathrm{kGy}$ e, posteriormente, sulfonado.

As curvas de DSC das membranas sulfonadas, aqui representadas pelo FEP enxertado em metanol, PFA enxertado em isopropanol e ETFE enxertado em tolueno, são apresentadas na FIG 35. As temperaturas observadas entre 100 e $200{ }^{\circ} \mathrm{C}$ sugerem a decomposição dos grupos hidrofílicos [79, 80]. Em todos os filmes sulfonados a $T_{f}$ referente ao polímero permaneceu igual à do filme 
prístino, estando em concordância com outros trabalhos encontrados na literatura $[79,80]$.

Nas membranas de FEP enxertadas a 20 e 40 kGy (FIG 35 a curvas azul e verde) os grupos hidrofílicos são eliminados a temperatura mais alta que as demais doses.

Na FIG 35 b, referente à membrana de PFA sulfonada a 20 e 40 kGy sugere-se que os grupos sulfônicos estejam sendo eliminados concomitante à fusão do polímero. O pico mais intenso verificado na enxertia a $20 \mathrm{kGy}$ (curva azul) sugere que a membrana reteve maior quantidade de água na condição da análise.

O DSC da membrana de ETFE, FIG 35 c, sugere uma perda de água e grupos sulfônicos a $123^{\circ} \mathrm{C}$. 


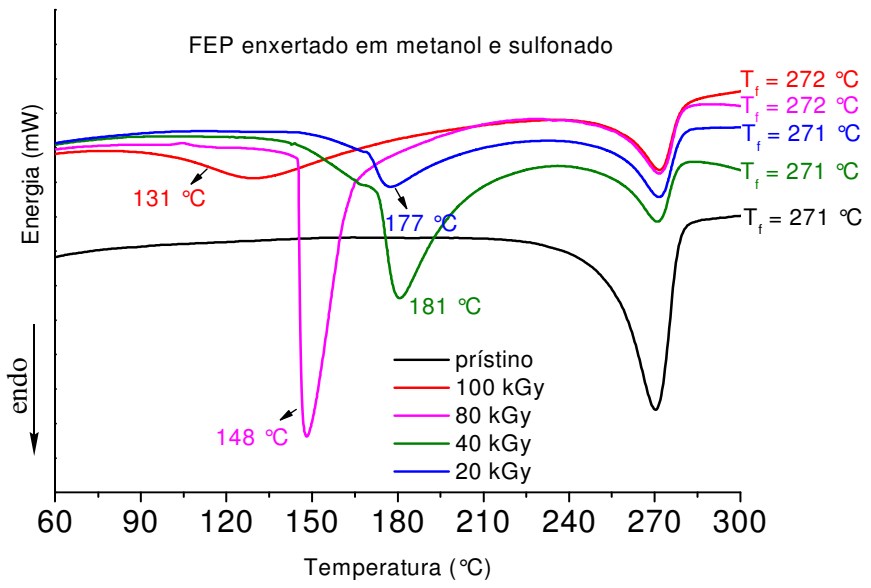

(a)

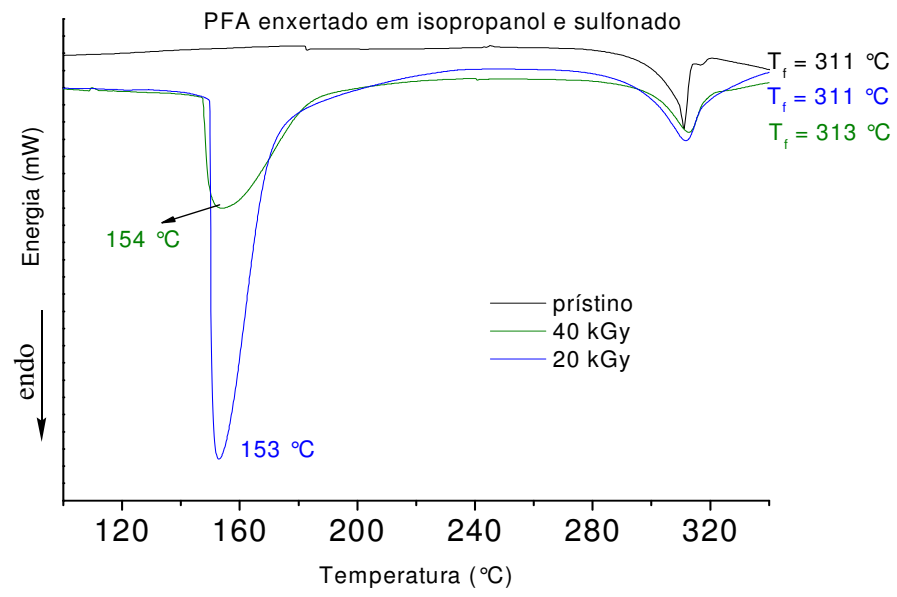

(b)

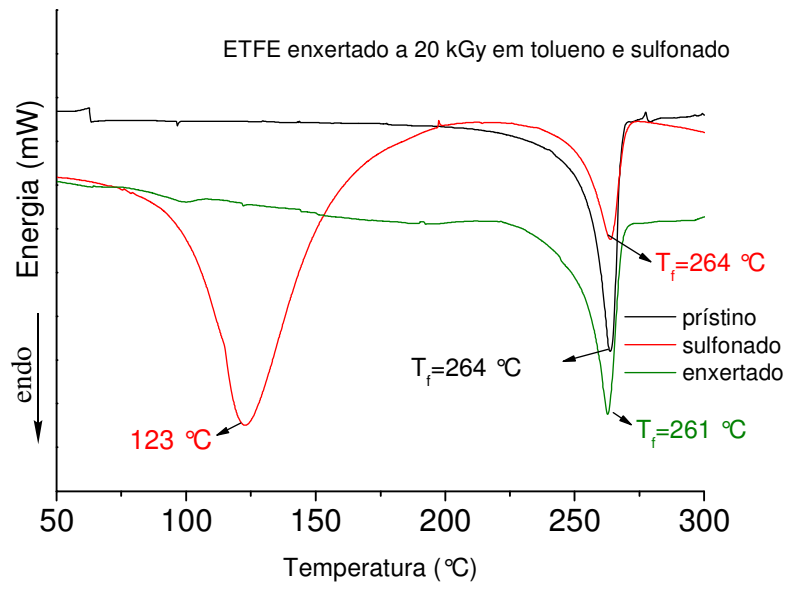

(c)

FIGURA 35: Curvas de DSC das membranas de FEP (a), PFA (b) e ETFE (c). 


\subsection{Testes em célula - curvas de polarização}

A TABELA 12 descreve os valores experimentais da IEC das membranas testadas em célula a combustível. Nota-se um valor superior ao determinado para o Nafion ${ }^{\circledR} 115$, IEC: 0,9 meq g $^{-1}$.

O desempenho eletroquímico de uma célula a combustível pode ser avaliado por meio de uma curva de polarização que consiste no levantamento das diferenças de potenciais geradas por uma célula para diferentes valores de correntes [81]. Tais curvas representam as características da corrente e da voltagem das reações eletroquímicas que ocorrem nos MEAs.

Foram preparados MEAs com as membranas de ETFE, PFA e FEP preparadas a $20 \mathrm{kGy}$ enxertadas em meio de tolueno. Os MEAs preparados com as membranas de PTFE não geraram corrente.

As membranas preparadas em isopropanol e metanol mostraram-se frágeis à prensagem, não suportando o processo necessário para a adesão dos eletrodos para a montagem dos MEAs.

TABELA 12: Capacidade de troca iônica (IEC) experimental e espessura das membranas de ETFE, FEP e PFA no tempo de sulfonação de 4 horas. Dose de 20 kGy.

\begin{tabular}{ccccc}
\hline Membrana & DOG (\%) & $\mathrm{IEC}_{\exp }\left(\mathrm{meq} \mathrm{g}^{-1}\right)$ & $\mathrm{Esp}^{1}(\mathrm{~mm})$ & $\mathrm{Esp}^{2}(\mathrm{~mm})$ \\
\hline ETFE & 71,9 & 1,98 & 0,24 & 0,20 \\
\hline FEP & 34,5 & 1,71 & 0,16 & 0,14 \\
\hline PFA & 35,8 & 1,66 & 0,17 & 0,15
\end{tabular}

DOG: grau de enxertia; Esp: espessura da membrana; ': membrana úmida; ${ }^{2}$ : membrana seca; $\mathrm{IEC}_{\text {exp }}$ : capacidade de troca iônica experimental.

As curvas de polarização das membranas ETFE, FEP e PFA comparadas ao Nafion ${ }^{\circledR}$ estão apresentadas nas figuras 36 a 41 . 
Nas FIGs 36, 37 e 38 são apresentadas as curvas de polarização dos MEAs utilizando os eletrólitos ETFE, FEP e PFA, respectivamente, comparados ao Nafion ${ }^{\circledR}$, com os reagentes $\mathrm{H}_{2}$ e $\mathrm{O}_{2}$ umidificados. Na região de ativação (0 a 0,2 $\mathrm{A} \mathrm{cm}^{-2}$ ) os MEAs preparados com os eletrólitos de ETFE, FEP e PFA mostram um decréscimo na região de ativação quando comparados ao Nafion ${ }^{\circledR}$. O desempenho dos eletrólitos de ETFE (FIG 36) e FEP (FIG 37) é maior na região predominantemente de queda ôhmica $\left(0,2\right.$ a $\left.1,0 \mathrm{~cm}^{-2}\right)$, que pode ser atribuída à maior condutividade iônica das membranas em comparação ao Nafion ${ }^{\circledR}$, levandose em consideração que a membrana apresenta maior espessura. Para o MEA preparado com PFA, o desempenho em célula, nesta região, mostrou-se menor quando comparado ao Nafion ${ }^{\circledR}$ (FIG 38).

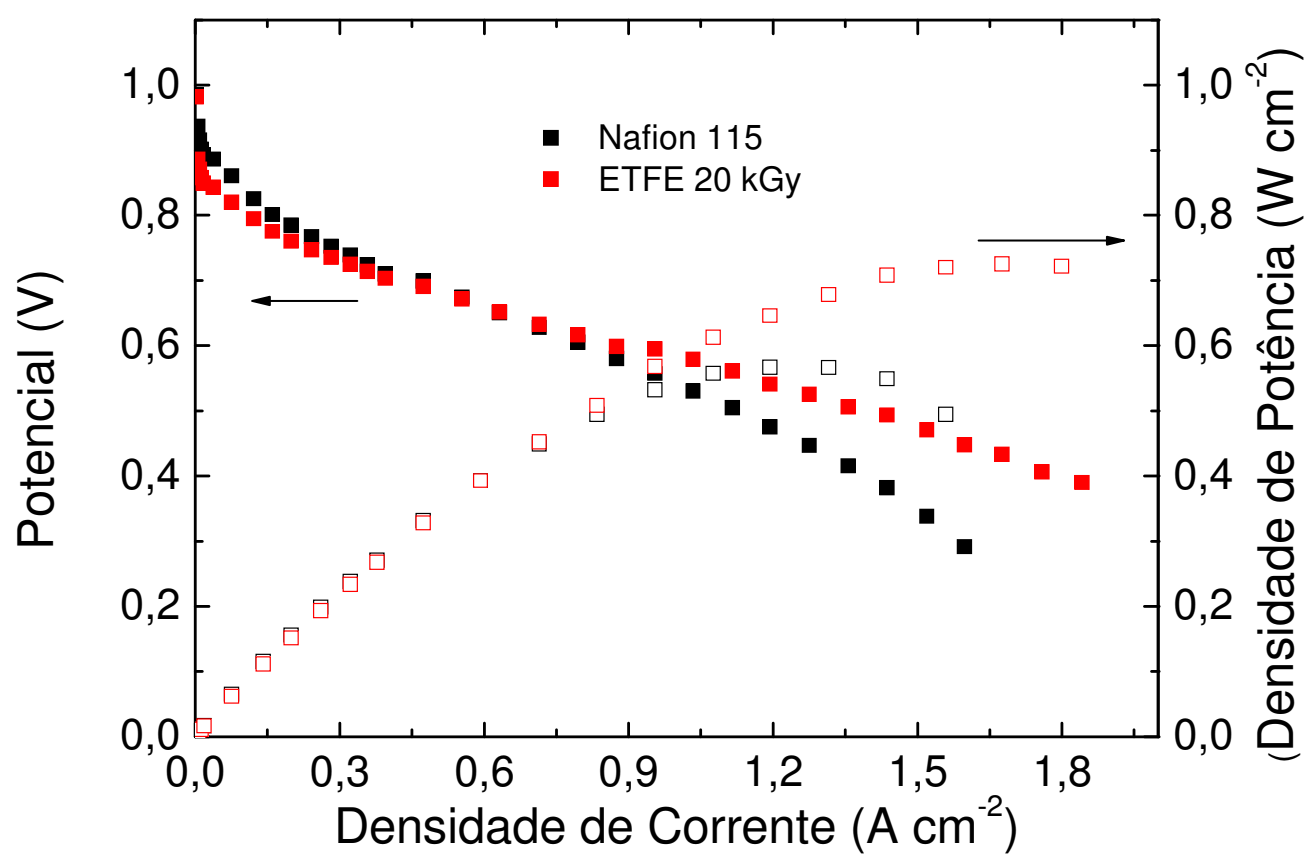

FIGURA 36: Curvas de polarização em célula unitária. Eletrólitos: Nafion ${ }^{\circledR} \mathrm{e}$ ETFE. Temperatura da célula $80{ }^{\circ} \mathrm{C}, \mathrm{H}_{2}$ umidificado a $95{ }^{\circ} \mathrm{C}$ e $\mathrm{O}_{2}$ umidificado a $85^{\circ} \mathrm{C}$.

Considerando-se as máximas densidades de potência (ordenada $Y$ à direita) dos eletrólitos ETFE e FEP (FIGs 36 e 37), o desempenho foi 23 e 16 \% 
respectivamente, comparáveis ao Nafion ${ }^{\circledR}$. Nas condições de operação com os gases de alimentação umidificados os MEAs preparados falharam em poucas horas.

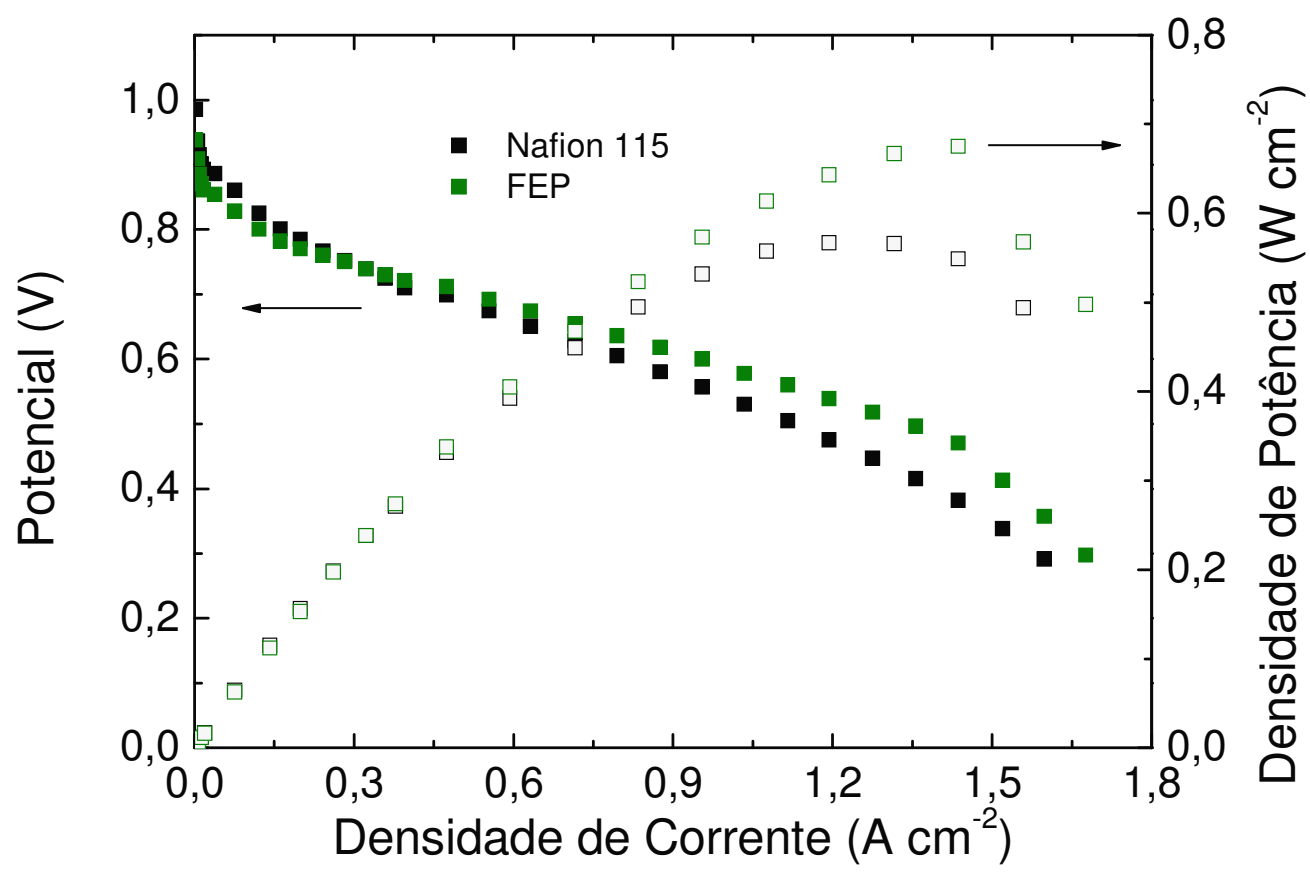

FIGURA 37: Curvas de polarização em célula unitária. Eletrólitos: Nafion ${ }^{\circledR}$ e FEP. Temperatura da célula $80{ }^{\circ} \mathrm{C}, \mathrm{H}_{2}$ umidificado a $95{ }^{\circ} \mathrm{C}$ e $\mathrm{O}_{2}$ umidificado a $85{ }^{\circ} \mathrm{C}$. 


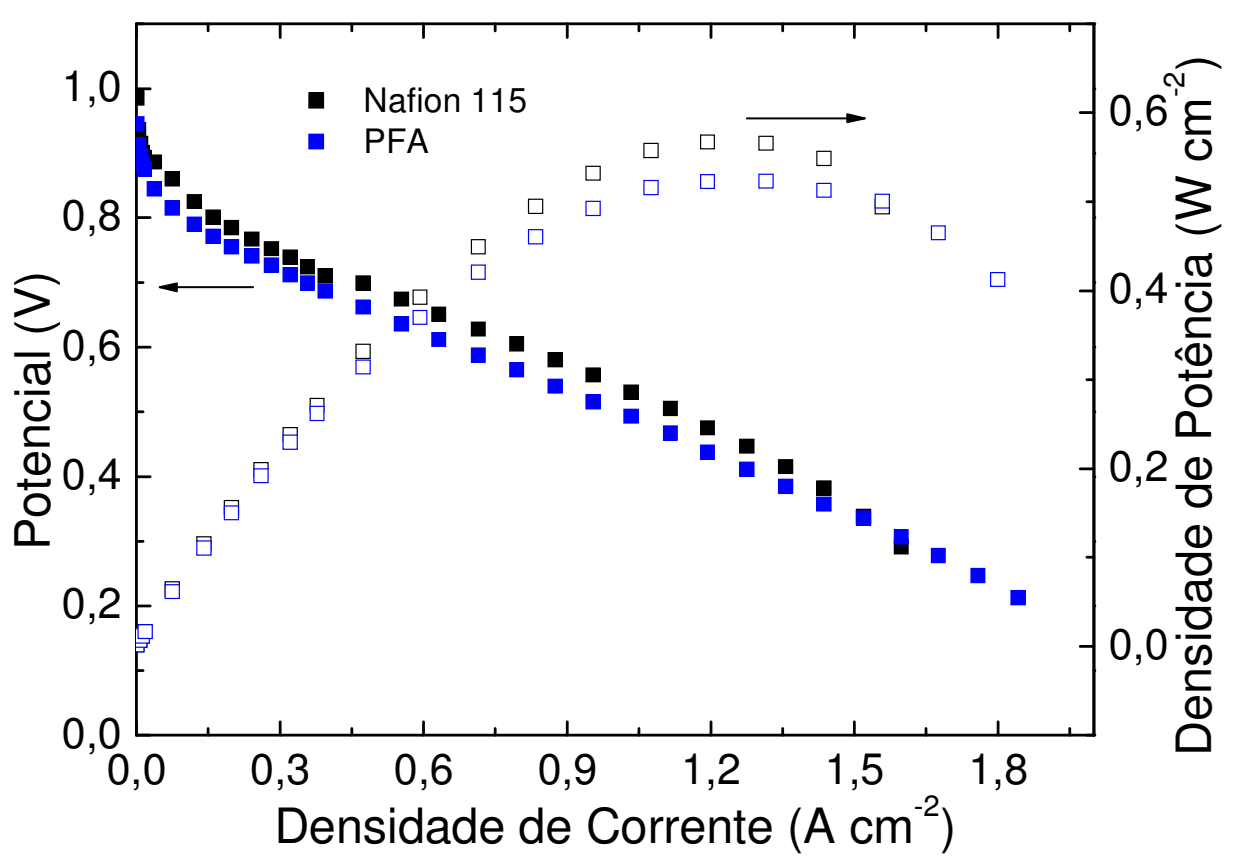

FIGURA 38: Curvas de polarização em célula unitária. Eletrólitos: Nafion ${ }^{\circledR}$ e PFA. Temperatura da célula $80{ }^{\circ} \mathrm{C}, \mathrm{H}_{2}$ umidificado a $95{ }^{\circ} \mathrm{C}$ e $\mathrm{O}_{2}$ umidificado a $85^{\circ} \mathrm{C}$.

As falhas no desempenho dos MEAs podem ser atribuídas à desidratação da membrana, à diferente microestrutura da parte hidrofílica da membrana (tamanho e localização dos enxertos na matriz polimérica) provocando diferença no transporte de água, à interface membrana-eletrodo, que também ocorre nas membranas de $\mathrm{Nafion}^{\circledR}$, e a buracos ou rasgos que foram observados em alguns experimentos.

As FIGs 39, 40 e 41 ilustram as curvas de polarização (a) e densidade de potência (b) em função do tempo de operação para célula a combustível com hidrogênio saturado em água e oxigênio seco. O desempenho do Nafion ${ }^{\circledR} 115$ após 2 horas é usado para comparação. O tempo total de operação até a falha dos eletrólitos foi de 28 horas para as membranas de ETFE e PFA, enquanto que o eletrólito de FEP falhou com 30 horas de operação. Nestas condições, os MEAs de ETFE (FIG 39a) e FEP (FIG 40a) tiveram desempenho global inferior ao 
Nafion ${ }^{\circledR}$. Já o desempenho do eletrólito de PFA foi idêntico ou superior ao Nafion ${ }^{\circledR}$ até 14 horas de operação.

Um desempenho oscilatório é notado em todos os eletrólitos estudados. Por exemplo, no ETFE o desempenho tende a decrescer até 12 horas de operação. Após 14 horas de operação um aumento na densidade de potencia (FIG 39b) é observado e as medidas obtidas nos tempos acima de 18 horas revelam uma diminuição no desempenho. Foi observado, portanto uma perda de desempenho global em função do tempo de polarização, sendo mais significativa após 22 horas de operação continua. Tal comportamento pode estar relacionado à degradação física ou química da membrana.

O eletrólito de PFA, considerando-se a máxima densidade de potência (FIG 41b) mostrou um desempenho 11\% superior até 14 horas de operação, com uma queda brusca após este período. 

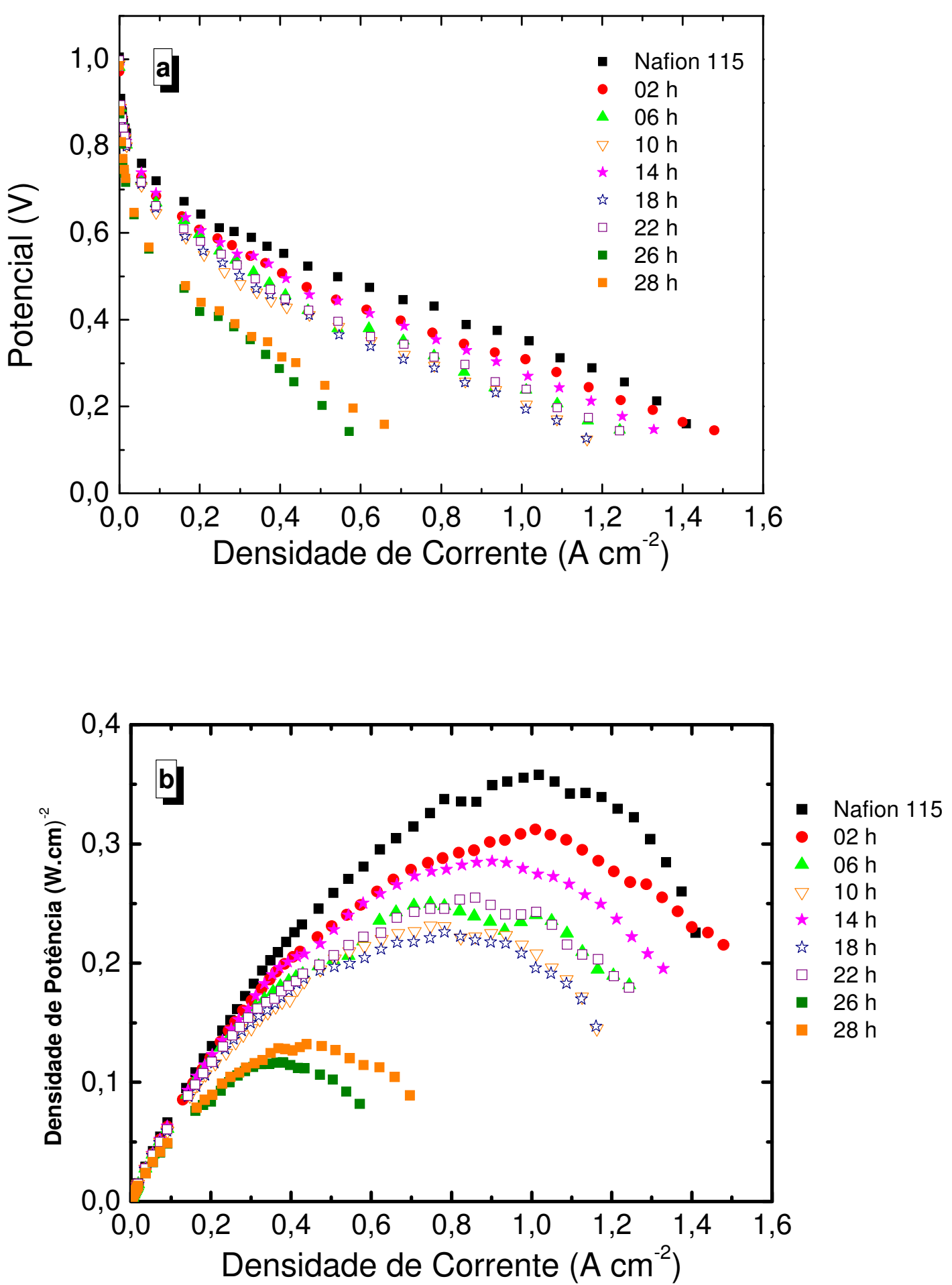

FIGURA 39: Curvas de polarização (a) e curvas de densidade de potência (b). Eletrólitos: Nafion ${ }^{\circledR}$ e ETFE. Temperatura da célula $80{ }^{\circ} \mathrm{C}, \mathrm{H}_{2}$ umidificado a $80{ }^{\circ} \mathrm{C}$ e $\mathrm{O}_{2}$ seco. 

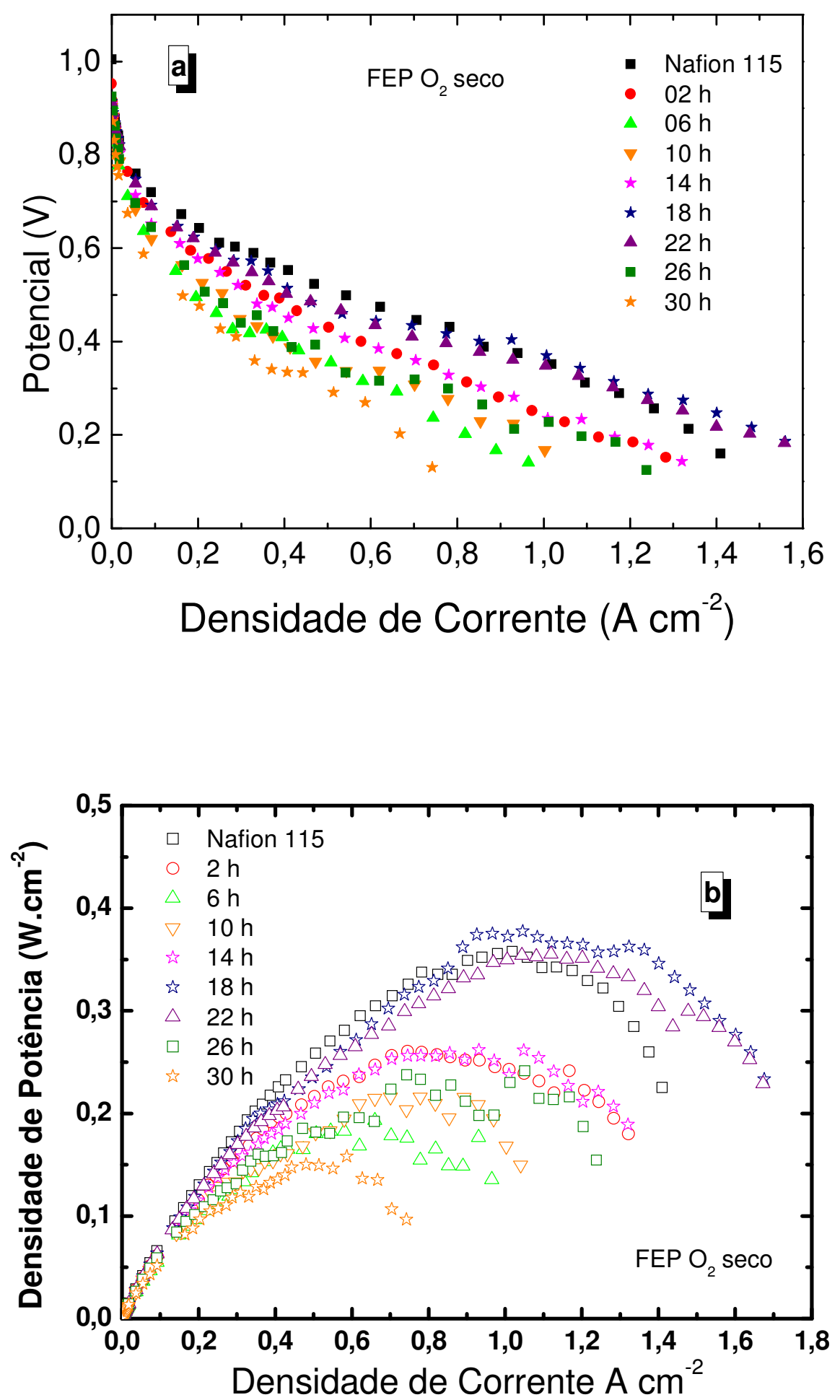

FIGURA 40: Curvas de polarização (a) e curvas de densidade de potência (b). Eletrólitos: Nafion ${ }^{\circledR}$ e FEP. Temperatura da célula $80{ }^{\circ} \mathrm{C}, \mathrm{H}_{2}$ umidificado a $80{ }^{\circ} \mathrm{C}$ e $\mathrm{O}_{2}$ seco. 

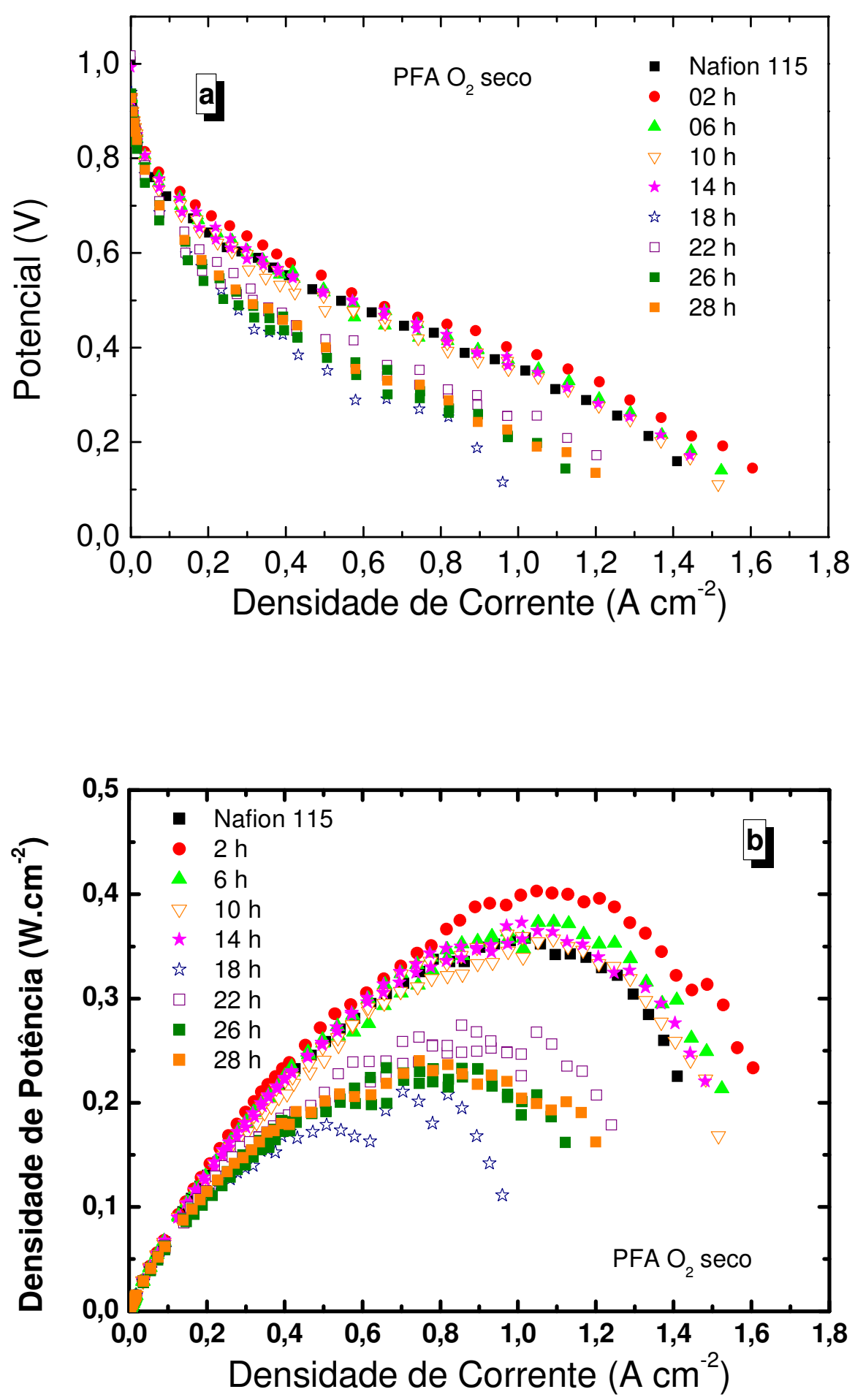

FIGURA 41: Curvas de polarização (a) e curvas de densidade de potência (b). Eletrólitos: Nafion ${ }^{\circledR}$ e PFA. Temperatura da célula $80{ }^{\circ} \mathrm{C}, \mathrm{H}_{2}$ umidificado a $80{ }^{\circ} \mathrm{C}$ e $\mathrm{O}_{2}$ seco. 
O desempenho de células a combustível unitária usando oxigênio seco foi estudado por GUBLER et al. [9] com membranas de ETFE e FEP. Quando comparadas ao Nafion ${ }^{\circledR}$ estas membranas tiveram desempenho inferior quanto maior o grau de enxertia nas mesmas. No mesmo trabalho, não foi possível avaliar o desempenho das membranas de ETFE com $51,7 \%$ de grau de enxertia, pois os MEAs preparados apresentaram buracos ou rasgos.

O gerenciamento de água na célula foi avaliado por ANDREAUS e SCHERER [82] em membranas Nafion ${ }^{\circledR}$ de diferentes espessuras. As condições de operação em célula envolveram a utilização de oxigênio seco. A altas densidades de corrente foi constatado que o conteúdo de água no ânodo decresce devido ao arraste eletro osmótico e às propriedades de transporte do polímero. O MEA ideal deve ser composto por eletrólito e eletrodos de pequena espessura, que sejam bons condutores de prótons e tenham porosidade suficiente para o transporte dos gases, com hidrofobicidade ideal para eliminar 0 alagamento.

Neste sentido, deve-se buscar as condições de operação ideais em célula, isto é, densidade de corrente, temperatura, pressão, umidificação dos gases reagentes, estequiometria e fluxo dos gases, de tal forma que as membranas preparadas possam responder com um desempenho satisfatório. 


\section{CONCLUSÃO}

A enxertia de estireno em fluoropolímeros à temperatura ambiente é possível, tendo em vista os resultados obtidos.

A metodologia de preparo dos filmes mostrou-se eficiente graças ao aumento no grau de enxertia. O grau de enxertia depende do solvente.

Os filmes enxertados em tolueno apresentam enxertias com valores médios maiores e mais próximos que os filmes enxertados nos diluentes isopropanol e metanol.

Pela técnica de espectroscopia no infravermelho foi possível confirmar a presença do estireno nos filmes enxertados.

A distribuição dos enxertos foi dependente da difusão do estireno na matriz polimérica, que está ligado à escolha do solvente. Os solventes que formam homopolímero (metanol e isopropanol), verificado pelo aumento da viscosidade da solução, parece favorecer uma enxertia superficial.

As membranas enxertadas em tolueno, que parece favorecer uma enxertia mais penetrada na matriz foram as que geraram corrente nos testes em célula a combustível.

Os testes em célula unitária das membranas de ETFE, PFA e FEP apresentaram uma resposta de polarização satisfatória em células a combustível de baixa temperatura quando comparadas à membrana Nafion ${ }^{\circledR}$ que é atualmente o estado de arte. 


\section{TRABALHOS FUTUROS}

Melhorar a vida útil da célula evitando o ataque oxidativo do hidrogênio benzílico do estireno enxertado usando metil estireno, bem como agentes de reticulação, como divinilbenzeno e outros.

Trabalhar com doses baixas utilizando feixe de elétrons.

Realizar as enxertias pelos métodos de pré irradiação e peroxidação.

Ajustar as melhores condições de operação em célula a combustível, tais como, densidade de corrente, temperatura, pressão, umidificação dos gases reagentes, estequiometria e fluxo dos gases, para aumentar o tempo de vida dos eletrólitos. 


\section{REFERÊNCIAS BIBLIOGRÁFICAS}

1. LEON YU., T.; HSIU-LI, L.; KUN-SHENG, S.; LI-NING, H.; YU-CHEN, C.; GUO-BIN, J.; HUANG J. C., Nafion ${ }^{\circledR} /$ PTFE Composites Membranes for Fuel Cell Applications. J. Polym. Res., 11, 217-224, 2004.

2. JONES, R. H.; THOMAS, G. J. Materials for the Hydrogen Economy. Boca Raton, CRC Press, cap 12, Materials for proton exchange membrane fuel cells. p. 274-293, 2007.

3. GUBLER, L.; GÜRSEL, S. A.; SCHERER, G. G.; Radiation Grafted Membranes for Polymer Electrolyte Fuel Cells. Fuel Cells, 5, 317-335, 2005.

4. GUBLER, L.; SLASKI, M.; WOKAUN, A.; SCHERER, G. G. Advanced monomer combination for radiation grafted fuel cell membranes. Electrochem. Commun., 8, 1215-1219, 2006.

5. GUPTA, B.; SCHERER, G. G. Proton exchange membranes by radiation grafting of styrene onto FEP films. I: Thermal characteristics of copolymer membranes. J. Appl. Polym. Sci., 50, 2129-2134, 1993.

6. GUPTA, B.; SCHERER, G. G.; Proton exchange membranes by radiationinduced graft copolymerization of monomers into teflon-FEP films. Chimia, 48, 127-137, 1994.

7. GUBLER, L.; BEN YOUCEF, H.; GÜRSEL, S. A.; WOKAUN, A.; SCHERER, G. G. Cross-Linker Effect in ETFE-Based Radiation-Grafted Proton-Conducting Membranes I. Properties and Fuel Cell Performance Characteristics. J. Electrochem. Soc., 155, B921-B928, 2008.

8. GUPTA, B.; BUECHI, F. N.; SCHERER, G. G.; CHAPIRO A., Development of membranes by radiation grafting of acrylamide into polyethylene films: Influence of synthesis conditions. J. Appl. Polym. Sci., 5, 493-499, 1994.

9. GUBLER, L.; PROST, N.; GÜRSEL, S. A.; SCHERER, G. G., Proton exchange membranes prepared by radiation grafting of styrene/divinylbenzene onto poly(ethylene-alt-tetrafluoroethylene) for low temperature fuel cells. Solid State Ionic, 176, 2849-2860, 2005. 
10. LI, Q.; HE, R.; JENSEN, J. O.; BJERRUM, N. J. Approaches and Recent Development of Polymer Electrolyte Membranes for Fuel Cells Operating above $100{ }^{\circ} \mathrm{C}$. Chem. Mater., 15, 4896-4915, 2003.

11. FLINT, S. D.; SLADE, R. C. T. Investigation of radiation-grafted PVDF-gpolystyrene-sulfonic-acid ion exchange membranes for use in hydrogen oxygen fuel cells. Solid State Ionic, 97, 299-307, 1997.

12. HIETALA, S.; HOLMBERG, S.; KARJALAINEN, M.; NASMAN, J.; PARONEN, M.; SERIMAA, R.; SUNDHOLM, F. Structural investigation of radiation grafted and sulfonated poly(vinylidene fluoride), PVDF, membranes. J. Mater. Chem., 7, 721-726, 1997.

13. HIETALA, S.; KOEL, M.; SKOU, E.; ELOMAA, M.; SUNDHOLM, F. Thermal stability of styrene grafted and sulfonated proton conducting membranes based on poly(vinylidene fluoride). J. Mater. Chem., 8, 1127-1132, 1998.

14. LI, J.; MATSUURA, A.; KAKIGI, T.; MIURA, T.; OSHIMA, A.; WASHIO, M. Performance of membrane electrode assemblies based on proton exchange membranes prepared by pre-irradiation induced grafting. $\boldsymbol{J}$. Power Sources, 161, 99-105, 2006.

15. LI, J.; MUTOU, F.; MIURA, T.; OSHIMA, A.; WASHIO, M.; IKEDA, S.; MATSUURA, C. ; KATSUMURA, Y. Improving the properties of the proton exchange membranes by introducing a-methylstyrene in the pre-irradiation induced graft polymerization. Eur. Polym. J., 42, 1222-1228, 2006.

16. LI, J.; ICHIDURI, S.; ASANO, S.; MUTOU, F.; MIURA, T.; OSHIMA, A.; TABATA, Y. ; WASHIO, M. Proton exchange membranes prepared by grafting of styrene/divinylbenzene into crosslinked PTFE membranes. Nucl. Inst. Meth. in Phys. Res. B, 236, 333-337, 2005.

17. LI, J.; SATO, K.; ICHIDURI, S.; ASANO, S.; IKEDA, S.; IIDA, M.; OSHIMA, A.; TABATA, Y.; WASHIO, M. Pre-irradiation induced grafting of styrene into crosslinked and non-crosslinked polytetrafluoroethylene films for polymer electrolyte fuel cell applications. II: Characterization of the styrene grafted films. Eur. Polym. J., 41, 547-555, 2005.

18. WALSBY, N.; PARONEN, M.; JUHANOJA, J.; SUNDHOLM F. Radiation grafting of styrene onto poly(vinylidene fluoride) films in propanol: the influence of solvent and synthesis conditions. J. Polym. Sci.: A, 38, 15121519, 2000.

19. WENDT, H.; GÖTZ, M.; LINARDI, M. Tecnologia de Células a Combustível. Química Nova, 23 (4), 538-546, 2000. 
20.GOTTESFELD, S.; ZAWODZINSKI, T.A. Advances in Electrochemical Science and Engineering. Weinhein, Germany. Wiley-VCH., 1997.

21. EISEMBERG, A.; YEAGER, H., Perfluorinated lonomer Membranes. ACS SYMPOSIUM SERIES 180, 489, 1982.

22. CHARLESBY A. The effects of ionizing radiation on polymers In: CLEGG D. W.; COLLYER A. A. (Ed) Irradiation effects on polymers, New York, Elsevier Applied Science, cap. 2, 1991.

23. CHARLESBY A. Radiation chemistry of polymers In: FARHTAZIZ P.; RODGERS M. A. J. (Ed) Radiation Chemistry: principles and applications, $\mathrm{VCH}$, cap.15, 1987

24. CHEN, J.; ASANO, M.; MAEKAWA, Y.; YOSHIDA, M. Suitability of some fluoropolymers used as base films for preparation of polymer electrolyte fuel cell membranes. J. Memb. Sci., 277, 249-257, 2006.

25. OSHIMA, A.; IKEDA, S.; KATOH, E.; TABATA, Y. Chemical structure and physical properties of radiation-induced crosslinking of polytetrafluoroethylene. Radiat. Phys. Chem., 62, 39-45, 2001.

26. LI, J.; SATO, K.; ICHIDURI, S.; ASANO, S.; IKEDA, S.; IIDA, M.; OSHIMA, A.; TABATA, Y.; WASHIO, M. Pre-irradiation induced grafting of styrene into crosslinked and non-crosslinked polytetrafluoroethylene films for polymer electrolyte fuel cell applications. I: Influence of styrene grafting conditions. Eur. Polym. J., 40, 775-783, 2004.

27.SATO, K.; IKEDA, S.; IIDA, M.; OSHIMA, A.; TABATA, Y.; WASHIO, M. Study on poly-eletrolyte membrane of crosslinked PTFE by radiationgrafting. Nucl. Instrum. Meth., B208, 424-428, 2003.

28. CHEN, J.; ASANO, M.; YAMAKI, T.; YOSHIDA, M. Preparation of sulfonated crosslinked PTFE-graft-poly(alkyl vinyl ether) membranes for polymer electrolyte membrane fuel cells by radiation processing. J. Memb. Sci., 256, 38-45, 2005.

29. TABATA, Y.; IKEDA, S.; OSHIMA, A. Radiation-induced crosslinking and grafting of polytetrafluoroethylene. Nucl. Inst. Meth. in Phys. Res. B 185, 169-174, 2001.

30. LAPPAN, U.; GEIBLER, U.; LUNKWITZ, K. Changes in the chemical structure of polytetrafluoroethylene induced by electron beam irradiation in the molten state. Radiat. Phys. Chem. 59, 317-322, 2000. 
31.BUCHI, F. N.; GUPTA, B.; HASS, O.; SCHERER, G. G. Study of radiationgrafted FEP-g-polkystyrene membranes as polymer electrolytes in fuell cells. Electrochim. Acta 40, 345-353, 1995.

32. BUCHI, F. N.; GUPTA, B.; HASS, O.; SCHERER G. G. Performance of differently crosslynked, partially fluorinated fuel cell membranes in polymer electrolyte fuel cells. J. Electrochem. Soc. 142, 3044-3048, 1995.

33. HUSLAGE, J.; RAGER, T.; SCHNYDER, B.; TSUKADA, A. Radiationgrafted membrane/electrode assemblies with improved interface. Electrochim. Acta, 48, 247-254, 2002.

34.NASEF, M. M.; SAIDI, H.; NOR, H. M.; FOO, O. M. Cation exchange membranes by radiation-induced graft copolymerization of styrene onto PFA copolymer films. II. Characterization of sulfonated graft copolymer membranes. J. Appl. Polym. Sci., 76, 1-11, 2002.

35. NASEF, M. M.; SAIDI, H. Preparation of crosslinked cation exchange membranes by radiation grafting of styrene/divinylbenzene mixtures onto PFA films. J. Membr. Sci., 216, 27-38, 2003.

36. DARGAVILLE, T. R.; HILL, D. J. T.; PERERA, S., Grafted fluoropolymers as supports for solid-phase organic chemistry: preparation and characterization. Aust. J. Chem., 55, 439-441, 2002.

37.PARK, K. R.; KANG, P. H.; NHO, Y. C. Preparation of PFA-g-polystyrene sulfonic acid membranes by the gamma-radiation grafting of styrene onto PFA films. Reactive \& Functional Polymers, 65, 47-56, 2005.

38. NASEF, M. M.; SAIDI, H.; DAHLAN, K. Z. M. Electron beam irradiation effects on ethylene-tetrafluoroethylene copolymer films. Radiat. Phys. Chem., 68, 875-883, 2003.

39. NASEF, M. M.; DAHLAN, K. Z. M. Electron irradiation effects on partially fluorinated polymer films: Structure-property relationships. Nucl. Inst. Meth. in Phys. Res. B, 201, 604-614, 2003.

40.HORSFALL, J. A.; LOVELL, K.V. Synthesis and Characterization of Sulfonic Acid-Containing Ion Exchange Membranes Based on Hydrocarbon and Fluorocarbon Polymers. Eur. Polym. J. 38, 1671-1682, 2002.

41. GUILMEAU, I.; ESNOUF, S.; BETZ, N.; MOEL, A. Kinetics and characterization of radiation-induced grating of styrene on fluoropolymers. Nucl. Inst. Meth. in Phys. Res. B, 131, 270-275, 1997. 
42.BRACK, H. P.; RUEGG, D.; BUHRER, H.; SLASKI, M.; ALKAN, S.; SCHERER, G. G. Differential scanning calorimetry and thermogravimetric analysis investigation of the thermal properties and degradation of some radiation-grafted films and membranes. J. Polym. Sci. B, 42, 2612-2624, 2004.

43. LEHTINEN, T.; SUNDHOLM, G.; HOLMBERG, S.; SUNDHOLM, F.; BJÖRNBOM P.; BURSELL, M. Electrochemical characterization of PVDFbased proton conducting membranes for fuel cells. Electrochim. Acta, 43, 1881-1890, 1998.

44. NASEF, M.M.; SAIDI, H. Structural, thermal and ion transport properties of radiation grafted lithium conductive polymer electrolytes. J. Mater. Chem., 99, 361-369, 2006.

45. MOKRINI, A.; HUNEAULT, M. A. Proton exchange membranes based on PVDF/SEBS blends. J. Power Sources, 154, 51-58, 2006.

46. KALLIO, T.; LUNDSTRÖM, M.; SUNDHOLM, G.; WALSBY, N.; SUNDHOLM, F. Electrochemical characterization of radiation-grafted ionexchange membranes based on different matrix polymers. J. Appl. Electrochem. 32, 11-18, 2002.

47.SHEN, M.; ROY, S.; KUHLMANN, J.W.; SCOTT, K.; LOVELL, K.; HORSFALL, J.A. Grafted polymer electrolyte membrane for direct methanol fuel cells. J. Membr. Sci., 251, 121-130, 2005.

48. ARICÒ, A. S.; BAGLIO, V.; CRETÌ, P.; DI BLASI, A.; ANTONUCCI, V.; BRUNEA, J.; CHAPOTOT, A.; BOZZI, A.; SCHOEMANS, J. Investigation of grafted ETFE-based polymer membranes as alternative electrolyte for direct methanol fuel cells. J. Power Sources, 123, 107-115, 2003.

49. SAARINEN, V.; KALLIO, T.; PARONEN, M.; TIKKANEN, P.; RAUHALA, E.; KONTTURI, K. New ETFE-based membrane for direct methanol fuel cell. Electrochim. Acta, 50, 3453-3460, 2005.

50.KALLIO, T.; JOKELA, K.; ERICSON, H.; SERIMAA, R.; SUNDHOLM, G.; JACOBSSON, P.; SUNDHOLM, F. Effects of a fuel cell test on the structure of irradiation grafted ion exchange membranes based on different fluoropolymers. J. Appl. Electrochem., 33, 505-514, 2003.

51. CHEN, J.; ASANO, M.; YAMAKI, T.; YOSHIDA, M. Preparation and characterization of chemically stable polymer electrolyte membranes by radiation-induced graft copolymerization of four monomers into ETFE films. J. Memb. Sci., 269, 194-204, 2006. 
52. CHEN, J.; ASANO, M.; YAMAKI, T.; YOSHIDA, M. Chemical and radiation crosslinked polymer electrolyte membranes prepared from radiation-grafted ETFE films for DMFC applications. J. Power Sources., 158, 69-77, 2006.

53. BHATTACHARYA, A.; MISRA, B. N. Grafting: a versatile means to modify polymers techniques, factors and applications. Prog. Polym. Sci. 29, 767814, 2004.

54.NASEF, M. M.; HEGAZY, E.A. Preparation and applications of ion exchange membranes by radiation-induced graft copolymerization of polar monomers onto non-polar films. Prog. Polym. Sci., 29, 499-561, 2004.

55. NASEF, M. M.; SAIDI, H.; NOR, H. M.; DAHLAN, K. Z. M.; HASHIM, K. Cation exchange membranes by radiation-induced graft copolymerization of styrene onto PFA copolymer films. I. Preparation and characterization of the graft copolymer. J. Appl. Polym. Sci., 73, 2035-2102, 1999.

56. NASEF, M. M.; SAIDI, H.; DESSOUKI, A. M.; EL-NESR, E. M. Radiationinduced grafting of styrene onto poly(tetrafluoroethylene) (PTFE) films. I. Effect of grafting conditions and properties of the grafted films. Polym. Int., 49, 399-406, 2000.

57.NASEF, M. M.; SAIDI, H.; NOR, H. M. Proton exchange membranes prepared by simultaneous radiation grafting of styrene onto poly(tetrafluoroethylene) films. I. Effect of grafting conditions. J. Appl. Polym. Sci., 76, 220-227, 2000.

58. NASEF, M. M. Effect solvents on radiation-induced grafting of styrene onto fluorinated polymer films. Polym. Int., 50, 338-346, 2001.

59. CARDONA, F.; GEORGE, G. A.; HILL, D. J. T.; RASOUL, F.; MAEJI, J. Copolymers obtained by the radiation-induced grafting of styrene onto poly(tetrafluoroethylene-co-perfluoropropylvinyl ether) substrates. I. Preparation ans structural investigation. Macromolecules, 35, 355-364, 2002.

60. GERALDES, A. N.; ZEN, H. A.; PARRA, D. F.; FERREIRA, H. P.; LUGÃO, A. B. Effects of solvents on post-irradiation grafting of styrene onto fluoropolymer films. e-Polymers, 63, 1-12, 2007.

61.HOLMBERG, S.; LEHTINEN, T.; NÄSMAN, J.; OSTROVSKII, D.; PARONEN, M.; SERIMAA, R.; SUNDHOLM, F.; SUNDHOLM, G.; TORELL, L.; TORKKELI, M. Structure and properties of sulfonated poly[(vinylidene fluoride)-g-styrene] porous membranes. J. Mater. Chem., 6, 1309-1317, 1996. 
62. DIETMAR, A.; STANGE, J.; MÜNSTEDT, H.; KRAUSE, B.; VOIGT, D.; LEDERER, A.; LAPPAN, U.; LUNKWITZ, K. Long-chain branched polypropylenes by electron beam irradiation and their rheological properties. Macromolecules, 37, 9465-9472, 2004.

63. YAMAKI, T.; KOBAYASHI, K.; ASANO, M.; KUBOTA, H.; YOSHIDA, M.; Preparation of proton exchange membranes based on crosslinked polytetrafluoroethylene for fuel cell. Polymer, 45, 6569-6573, 2004.

64.ZU, J.; WU, M.; FU, H.; YAO, S. Cation-exchange membranes by radiationinduced graft copolymerization of monomers onto HDPE. Radiat. Phys. Chem., 72, 759-764, 2005.

65. SHANG, X.; LI, X.; XIAO, M.; MENG, Y. Synthesis and characterization of sulfonated fluorine-containing poly(arylene ether ketone) for high temperature proton exchange membrane. Polymer, 47, 3807-3813, 2006.

66. SANTIAGO, E. I.; PAGANIN, V. A.; CARMO, M. do; GONZALEZ, E. R.; TICIANELLI, E. A. Studies of CO tolerance on modified gas diffusion electrodes containing ruthenium dispersed on carbon. J. Electroanal. Chem., 575, 53-60, 2005.

67.PAGANIN, V.A.; TICIANELLI, E.A.; GONZALEZ, E.R. Development and electrochemical studies of gas diffusion electrodes for polymer electrolyte fuel cells. J. Appl. Electrochem., 26, 297-300, 1996.

68. ASANO, S.; MUTOU, F.; ICHIZURI, S.; LI, J.; MIURA, T.; OSHIMA A.; KATSUMURA, Y.; WASHIO, M. Fabrication of PEFC membrane based on PTFE/FEP polymer-alloy using radiation-grafting. Nucl. Inst. Meth. in Phys. Res. B, 236, 437-442, 2005.

69. CARDONA, F.; HILL, D. J. T.; GEORGE, G.; MAEJI, J.; FIRAS, R.; PERERA, S. Thermal characterization of copolymers obtained by radiation grafting of styrene onto poly(tetrafluoroethylene-perfluoropropylvinylether) substrates: thermal decomposition, melting behavior and low-temperature transitions. Polym. Degrad. and Stability, 74, 219-227, 2001.

70.LAPPAN, U.; GEIBLER, U.; UHLMANN, S. Radiation-induced grafting of styrene into radiation-modified fluoropolymer films. Nucl. Inst. Meth. and Phys. Res. B, 236, 413-419, 2005.

71.NASEF, M. M.; SAIDI, H. Structure-property Relationships in Radiation Grafted Poly(tetrafluoroethylene)-graft-polystyrene Sulfonic Acid Membranes. J. Pol. Res. 12, 305-312, 2005.

72. ABDOU, S. M.; MOHAMED, R. I. Characterization of structural modifications in poly-tetra-fluoroethylene induced by electron beam irradiation. J. Phys. Chem. Solids, 63, 393-398, 2002. 
73.ZHONG, X.; YU, L.; ZHAO, W.; SUN, J.; ZHANG, Y. Radiation-induced crystal defects in PTFE. Polym. Degrad. Stab., 40, 97-100, 1993.

74. GUBLER L., BECK N., GÜRSEL S. A, HAJBOLOURI F., KRAMER D., REINER A., STEIGER B., SCHERER G. G., WOKAUN A., RAJESH B., THAMPI K. R., Materials for polymer electrolyte fuel cells. Chimia Int. J. Chem., 58, 826-832, 2004.

75. RAGER T. Pré-irradiation grafting of styrene/divinylbenzene onto poly(tetrafluoroethylene-co-hexafluoropropylene) from non-solvents. Helvetia Chimia Acta, 86, 1966-1981, 2003.

76.SHI Z., HOLDCROFT S. Synthesis and proton conductivity of partially sulfonated poly([vinylidene difluoride-co-hexafluoropropylene]-b-styrene) block copolymers. Macromolecules, 38,4193-4201,2005.

77. GAO Y., ROBERTSON G. P., GUIVER M. D., JIAN X., MIKHAILENKO S. D., WANG K., KALIAGUINE S. Sulfonation of poly(phtalazinones) with fuming sulfuric acid mixtures for proton exchange membrane materials. J. Memb. Sci., 227, 39-50, 2003.

78.SHANG X., LI X., XIAO M., MENG Y. Synthesis and characterization of sulfonated fluorine-containing poly(arylene ether ketone) for high temperature proton exchange membrane. Polymer, 47, 3807-3813, 2006.

79. GURSEL, S. A.; SCHNEIDER, J.; BEN YOUCEF, H.; WOKAUN, A.; SCHERER, G. G. Thermal properties of proton-conducting radiation-grafted membranes. J. Appl. Pol. Sci., 108, 3577-3585, 2008.

80.BEN YOUCEF, H.; GURSEL, S. A.; WOKAUN, A.; SCHERER, G. G. The influence of crosslinker on the properties of radiation-grafted films and membranes based on ETFE. J. Memb. Sci., 311, 208-215, 2008.

81. TICIANELLI, E. A.; GONZALEZ, E. R. Eletroquímica: Princípios e Aplicações, Edusp, p. 11-23, 2005.

82. ANDREAUS, B.; SCHERER, G. G. Proton-conducting polymer membranes in fuel cells-humidification aspects. Solid State Ionic, 168, 311-320, 2004. 